INTERNATIONAL MONETARY FUND

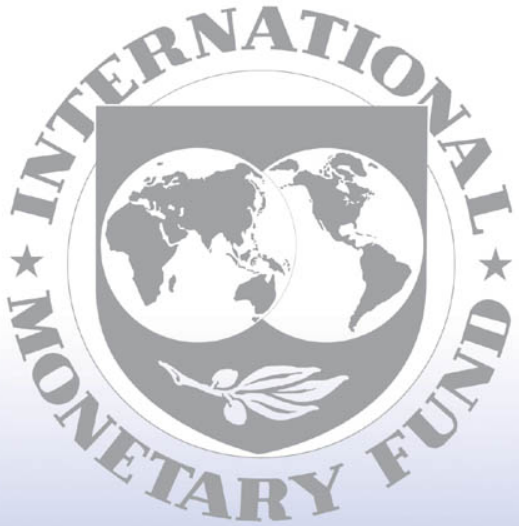

Staff

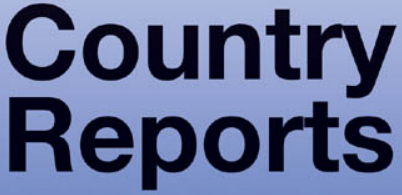




\section{Republic of Congo: First Review Under the Poverty Reduction and Growth Facility, and Requests for Waiver of Performance Criteria and Modification of Performance Criterion-Staff Report; Staff Statement; Press Release on the Executive Board Discussion; and Statement by the Executive Director for the Republic of Congo}

In the context of the first review under the three-year arrangement under the Poverty Reduction and Growth Facility, and requests for a waiver of performance criteria and a modification of a performance criterion with the Republic of Congo, the following documents have been released and are included in this package:

- the staff report for the first review under the Poverty Reduction and Growth Facility, and requests for waiver of performance criteria and modification of performance criterion, prepared by a staff team of the IMF, following discussions that ended on May 13, 2005, with the officials of the Republic of Congo on economic developments and policies. Based on information available at the time of these discussions, the staff report was completed on July 18, 2005. The views expressed in the staff report are those of the staff team and do not necessarily reflect the views of the Executive Board of the IMF.

- a staff statement of August 1, 2005 updating information on recent developments.

- $\quad$ a Press Release summarizing the views of the Executive Board as expressed during its August 1, 2005 discussion of the staff report that completed the review.

- $\quad$ a statement by the Executive Director for the Republic of Congo.

The documents listed below have been or will be separately released.

Letter of Intent sent to the IMF by the authorities of the Republic of Congo*

Memorandum of Economic and Financial Policies by the authorities of the Republic of Congo*

Technical Memorandum of Understanding*

*May also be included in the Staff Report

The policy of publication of staff reports and other documents allows for the deletion of market-sensitive information.

To assist the IMF in evaluating the publication policy, reader comments are invited and may be sent by e-mail to publicationpolicy@imf.org.

Copies of this report are available to the public from

International Monetary Fund • Publication Services

$70019^{\text {th }}$ Street, N.W. • Washington, D.C. 20431

Telephone: (202) 623-7430 • Telefax: (202) 623-7201

E-mail: publications@imf.org • Internet: http://www.imf.org

Price: $\$ 15.00$ a copy

\section{International Monetary Fund}

Washington, D.C.

CInternational Monetarv Fund. Not for Redistribution 
This page intentionally left blank 


\section{INTERNATIONAL MONETARY FUND}

\section{REPUBLIC OF CONGO}

\section{First Review Under the Poverty Reduction and Growth Facility Arrangement, and Requests for Waiver of Performance Criteria and Modification of Performance Criterion}

Prepared by the African Department

(In consultation with other departments)

Approved by Thomas Krueger and Anthony Boote

July 18, 2005

- The Executive Board, on December 6, 2004, approved a three-year arrangement under the Poverty Reduction and Growth Facility (PRGF) for the Republic of Congo (hereafter "Congo") in an amount equivalent to SDR 54.99 million (65 percent of quota).

- Discussions for the first review under the PRGF arrangement took place in Brazzaville during April 29-May 13, 2005, and via video link in June.

- The mission team consisted of Mr. Ghura (Head), Mr. Karangwa and Ms. Bhattacharya (all AFR), Mr. Op de Beke and Ms. Oliva (both PDR), and Mr. Moussa (FAD). Mr. Kudiwu, Advisor to the Executive Director for the Congo, participated in the discussions. The team worked closely with parallel missions from the World Bank and the African Development Bank (AfDB).

- The staff met with President Sassou-Nguesso; Prime Minister Mvouba; Senior Planning Minister Moussa; Finance Minister Issoïbeka; the National Director of the central bank, Mr. Dzon; other senior government officials; members of the parliament, senate, press and donors; and civil society representatives.

- The letter of intent (LOI), the memorandum of economic and financial policies (MEFP), and an addendum to the technical memorandum of understanding (TMU) are found in Appendix I. 


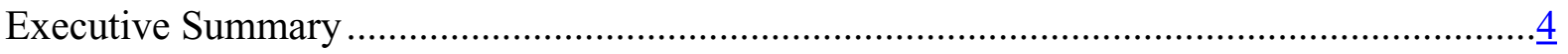

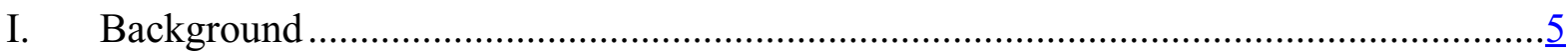

II. Recent Economic Developments .........................................................................

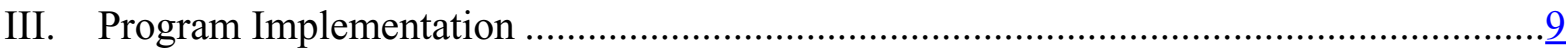

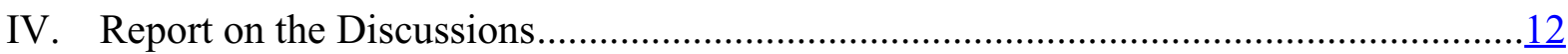

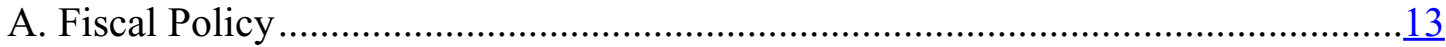

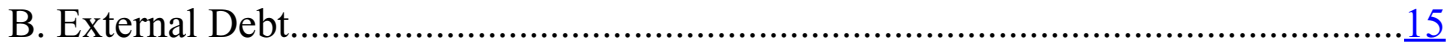

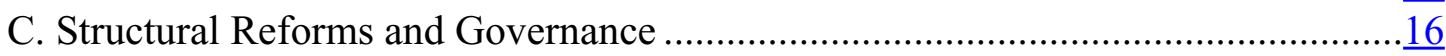

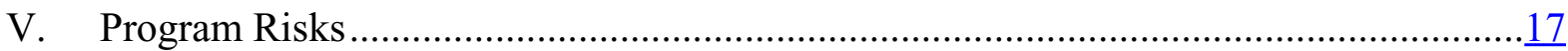

VI. Prior Actions and Program Monitoring …………..................................................

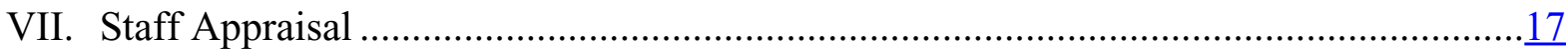

Boxes

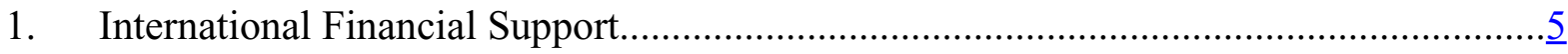

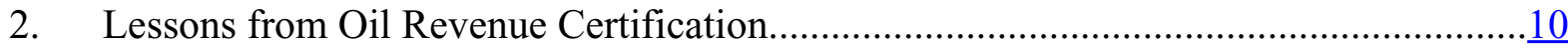

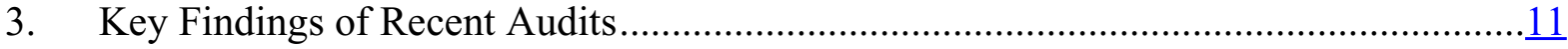

Figures

1. Output and Price Developments, 1990-2007 ……....................................................

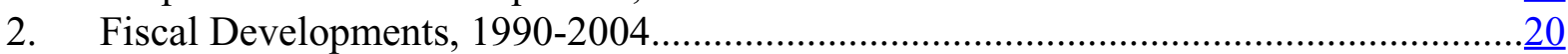

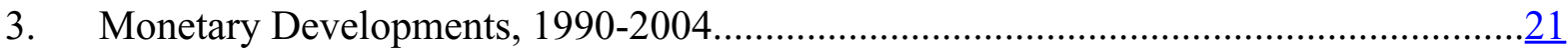

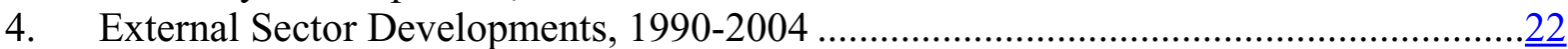

5. Effective Exchange Rates, March 1990-March 2005 ......................................................

Tables

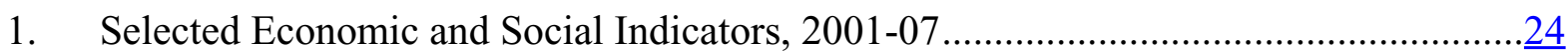

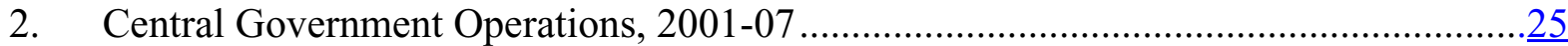

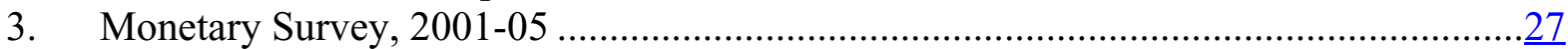

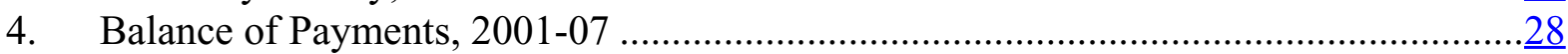

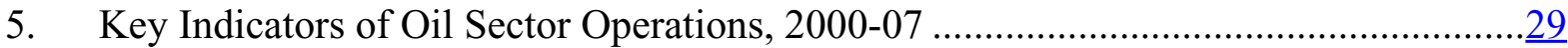

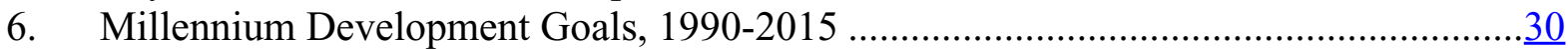

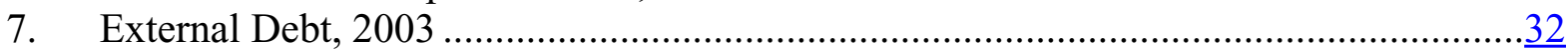

8. Elements of the Capacity to Pay External Debt, 2003-07 ...........................................33

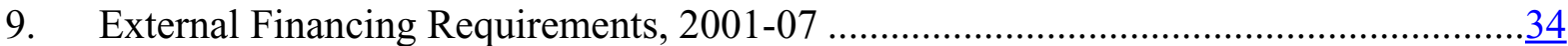

10. Proposed Schedule of Disbursements Under the PRGF Arrangement ............................

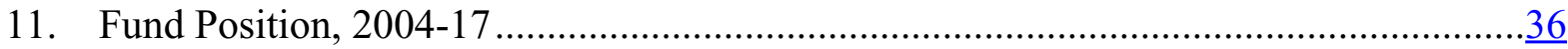

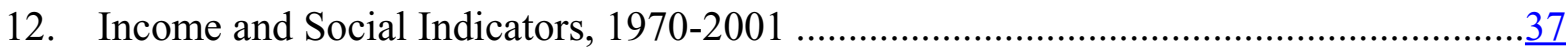


Appendices

I. Letter of Intent .........................................................................................

Attachment I: Memorandum of Economic and Financial Policies ..........................

Attachment II: Addendum to Technical Memorandum of Understanding ...............

II. Relations with the Fund ..............................................................................

III. Relations with the World Bank Group..............................................................

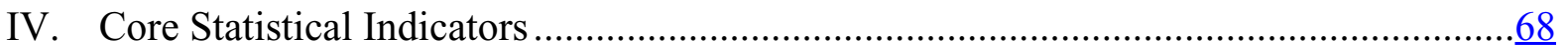




\section{EXECUTIVE SUMMARY}

The Congo continued in 2004 to make progress in strengthening macroeconomic conditions. Economic growth picked up, but inflation rose somewhat. Reflecting the rise in oil prices, the fiscal and current account balance position improved significantly.

Nonetheless, the banking system remains fragile, and banks are cautious about advancing credit.

\section{Program implementation under the PRGF arrangement was satisfactory during} October 2004-March 2005, notwithstanding some expenditure overruns in 2004. The government met most budgetary, monetary, and financial quantitative performance criteria and benchmarks. It took steps to further enhance oil sector transparency, including by publishing the 2003 audit report of the national oil company and the quarterly reports of the certification of oil revenues.

Implementation of the interim poverty reduction strategy paper (I-PRSP) in 2004 was weak. In particular, spending on basic health and education fell short of the target, partly because of the lack of trained personnel and the weak system for monitoring budget execution. The government is committed to tackling these shortcomings and to raising poverty-related outlays.

The Congo's medium-term prospects have improved significantly because of the rise in oil prices, notwithstanding the downward revision of oil production. The government needs to adhere to the revised fiscal targets to raise pro-poor outlays, avoid procyclical spending, and allow an increase in the primary budget surplus. Priorities for the use of windfall oil revenues, if they materialize, should include further raising poverty-related expenditures, reducing domestic arrears, settling arrears with external private creditors, and saving for future generations.

The full extent of deep-rooted structural weaknesses in the banking, fuel, and electricity sectors came to light in early 2005. Losses in the fuel sector, arrears by the national electricity company to its suppliers, and the costs of recapitalization and portfolio cleanup in the banking sector are estimated at about 4 percent of the Congo's 2004 GDP. Tackling structural weaknesses in these sectors is necessary to safeguard medium-term fiscal sustainability and the poverty reduction objective and to address governance concerns. The envisaged measures are ambitious and require broad political support. 


\section{BACKGROUND}

\section{Progress made by the Congo in consolidating political stability and} strengthening macroeconomic conditions was recognized by Executive Directors in approving the PRGF arrangement last December. Directors were encouraged by the country's improvements in oil sector transparency and budget management, and by the steps it has taken to normalize creditor relations. They stressed that the Congo needed to intensify its efforts to further improve oil sector transparency. Board approval of the PRGF arrangement paved the way for financing from the World Bank and the AfDB, and for debt rescheduling by the Paris Club (Box 1). ${ }^{1}$

\section{Box 1. International Financial Support}

Last December, the World Bank's Executive Board approved a US\$30 million Economic Recovery Credit (ERC) for the Congo, and the AfDB approved a grant of US\$50 million to absorb one-third of the Congo's arrears to that institution and a US\$10 million budgetary support loan. The Congo has also benefited from financial support from the European Union, as well as from bilateral donors.

On December 16, 2004 Paris Club creditors agreed to restructure the Congo's external debt. Total debt treated amounted to US\$3,020 million, of which US\$1,570 million was cancelled. The rest was rescheduled (on Naples terms) over the program period. Among other treatments, arrears on post-cutoff-date debt were rescheduled over the three-year program period.

2. The cabinet was reshuffled in early January 2005, and parliamentary elections are planned for later in $\mathbf{2 0 0 5}$ for the Pool region. Mr. Issoïbeka, former Deputy Governor of the Bank for the Central African States (BEAC), was appointed Finance Minister, and Mr. Itoua, former chairman of the national oil company (SNPC), was appointed Energy Minister. A key condition for successful elections is the laying down of arms by the rebels.

3. The security situation, though improving, remains fragile. The government is making good progress in its program for demobilizing former combatants, although it has experienced some delays. Among the sporadic security disruptions that have occurred were attacks by a rebel group in late 2004 on the vital Brazzaville-Pointe Noire rail line, forcing a suspension of services, and an attack on a United Nations convoy (though with no casualties) in April 2005; rail services have now been reestablished.

\footnotetext{
${ }^{1}$ Appendices II and III summarize the Congo's relations with the Fund and the World Bank.
} 


\section{RECENT ECONOMIC DEVELOPMENTS}

4. The international environment in 2004, with the strong increase in oil prices, was exceptionally favorable for the Congo.

Nonetheless, although the price (in U.S. dollars) of Brent oil rose by 33 percent, the average price (in CFA francs) of Congolese oil increased only by about 16 percent. This was due to the sharp rise in the world market discount on Congolese crude oil ${ }^{2}$ and to the appreciation of the euro (to which the CFA franc is tied) vis-à-vis the U.S. dollar. Oil sector developments dominated the Congo's macroeconomic performance in 2004, notwithstanding lower-than-programmed output.

\begin{tabular}{|c|c|c|c|}
\hline \multicolumn{4}{|c|}{$\begin{array}{l}\text { Congo: Oil Sector Indicators, 2003-04 } \\
\text { (In units indicated) }\end{array}$} \\
\hline & \multirow{2}{*}{$\begin{array}{r}2003 \\
\text { Est. }\end{array}$} & \multicolumn{2}{|c|}{2004} \\
\hline & & Prog. & Est. \\
\hline Oil price (Brent) $1 /$ & 28.8 & 37.1 & 38.3 \\
\hline Discount for Congolese crude 1/ & 1.6 & 2.3 & 3.6 \\
\hline Price for Congolese crude 2/ & 15.8 & 18.2 & 18.3 \\
\hline Production (in millions of barrels) & 81.7 & 83.3 & 82.1 \\
\hline \multicolumn{4}{|c|}{ Sources: Congolese authorities; and Fund staff estimates. } \\
\hline $\begin{array}{l}\text { 1/ U.S. dollars per barrel. } \\
\text { 2/ Thousand CFA francs/barrel. }\end{array}$ & & & \\
\hline
\end{tabular}

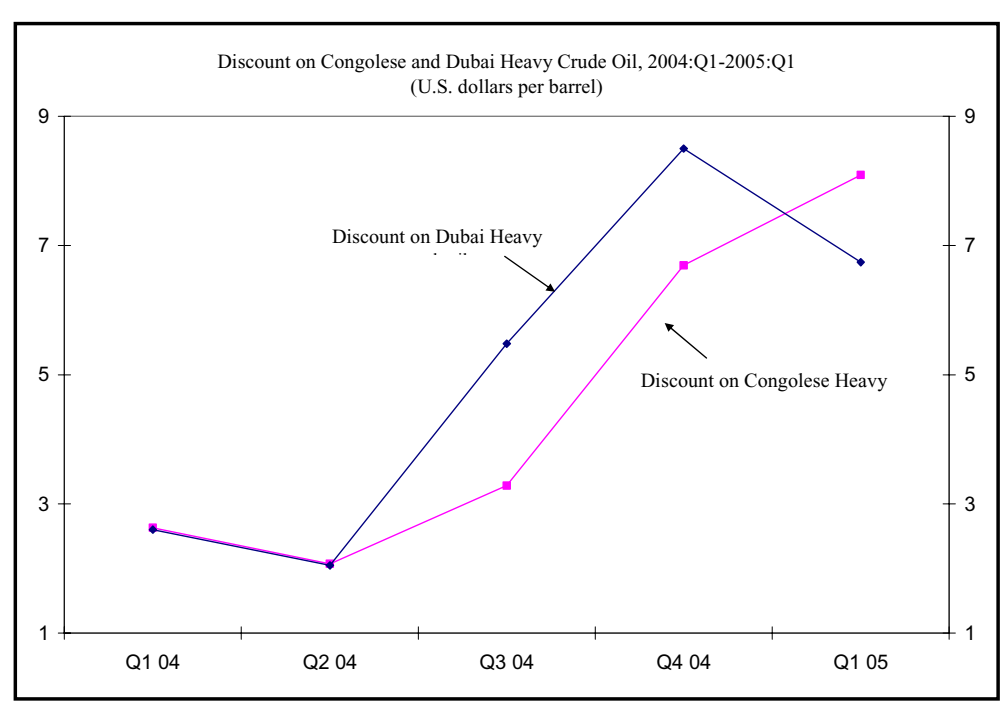

${ }^{2}$ Analysts note that the demand for lighter crude oil, such as Brent- - a widely used international benchmark - rose much faster than for heavy crude, such as Dubai Heavy. 


\section{Real GDP growth} rebounded in 2004 , but inflation picked up somewhat (Table 1, Figure 1). Real GDP growth is estimated at 3.6 percent in 2004 , reflecting favorable terms of trade, robust non-oil real GDP growth, and a slight increase in oil production (relative to 2003). Inflation reached 3.6 percent (period average) in 2004, primarily on account of supply disruptions on the Pointe Noire-Brazzaville rail line. Nonetheless, with the easing of these disruptions, the 12-month inflation rate declined to 2.7 percent in March 2005.
6. The Congo's fiscal position improved in 2004, despite expenditure overruns relative to the program (Table 2, Figure 2). Total revenues rose by 3 percentage points of GDP relative to 2003, the result of higher oil prices and improved tax and customs administration, including the reform of the computer system in the customs office at Pointe Noire. Primary expenditures exceeded the program by 0.5 percentage point of GDP, because investment projects in the remote north planned for the first half of 2005 were executed in the last quarter of 2004 in anticipation of lower water levels in the Congo River (used for transportation). Overall, the primary fiscal surplus increased by 3.8 percentage points of GDP relative to 2003 .

\section{Poverty-related spending} increased in 2004, but the target set under the I-PRSP was missed. The share of poverty-reducing outlays in primary spending was lower relative to the objective under the program and the I-PRSP. Underspending was greatest on basic health and education. In meeting the spending targets, the authorities were hindered by the

\begin{tabular}{|lrrr|}
\hline \multicolumn{4}{|c|}{ Congo: Pro-Poor Spending, 2003-04 } \\
(In billions of CFA francs, unless otherwise indicated) \\
\hline \multicolumn{4}{|c}{2003} \\
\cline { 2 - 4 } & Est. & Proj. & Est. \\
\hline Total & 83.4 & 109.9 & 102.1 \\
Basic health care and HIV/AIDS & 4.4 & 18.0 & 9.5 \\
Basic education & 33.9 & 41.2 & 36.8 \\
Infrastructure and rural integration & 5.9 & 30.4 & 29.8 \\
Water and electricity & 18.8 & 5.7 & 6.9 \\
Disarmament, demobilization, and reintegration & 18.0 & 13.1 & 17.4 \\
Social protection & 2.2 & 1.3 & 1.3 \\
Agriculture & 0.1 & 0.2 & 0.4 \\
Memorandum items & & & \\
Total pro-poor spending & & & \\
In percent of primary expenditure & 18.0 & 22.8 & 20.6 \\
In percent of GDP & 4.0 & 4.7 & 4.4 \\
\hline Sources: Congolese authorities; and Fund staff estimates. & & \\
\hline
\end{tabular}

\begin{tabular}{lccr|}
\hline \multicolumn{4}{|c|}{ Congo: Key Real Sector Indicators, 2003-04 } \\
(In units indicated) & & \\
\hline \multicolumn{4}{|c}{2003} \\
\cline { 3 - 4 } & Est. & Prog. & Est. \\
\hline Real GDP growth (in percent) & 0.8 & 4.0 & 3.6 \\
Oil & -7.2 & 2.0 & 0.5 \\
Non-oil & 5.4 & 5.0 & 5.2 \\
Inflation (in percent) & & & \\
Period average & 1.5 & 2.0 & 3.6 \\
End of period & 6.4 & $\ldots$ & 1.1 \\
Memorandum items: & & & \\
Terms of trade 1/ & 2.9 & 8.0 & 12.5 \\
Real effective exchange rate 1/ & 2.2 & $\ldots$ & 1.1 \\
\hline Sources: Congolese authorities; and Fund staff estimates and calculations. \\
1/ Percent change.
\end{tabular}

\begin{tabular}{|lrrr}
\hline \multicolumn{4}{c}{ Congo: Fiscal Performance, 2003-04 } \\
(In percent of GDP) \\
\hline & 2003 & & \\
\cline { 3 - 4 } & Est. & Prog. & Est. \\
\hline Domestic revenue (excl. grants) & 29.1 & 31.0 & 32.2 \\
Oil & 20.4 & 22.2 & 23.1 \\
Non-oil & 8.8 & 8.7 & 9.0 \\
Primary expenditure & 17.0 & 15.5 & 16.0 \\
Primary fiscal surplus & 6.7 & 10.1 & 10.5 \\
\hline
\end{tabular}

Sources: Congolese authorities; and Fund staff estimates. 
late start in I-PRSP implementation, the lack of trained personnel, and the weak monitoring system for budget execution.

\section{Monetary developments in $\mathbf{2 0 0 4}$ were marked by a strong expansion of net} foreign assets, but the banking system remains fragile. Broad money rose by about $17 \frac{1}{2}$ percent (Table 3, Figure 3). Credit growth was modest, however, reflecting a shortage of viable projects and banks' reluctance to lend, given the weaknesses of the legal framework for loan recovery. At end-December 2004 the regional banking supervisory agency (COBAC) classified two of the Congo's four banks as being in good condition; one bank was in a fragile financial state and one in critical condition. In December 2004 a restructuring plan for the bank in critical condition (COFIPA) was approved by its board. The government has temporarily taken over the bank to protect depositors, allow an orderly restructuring, and prepare it for reprivatization.

\section{The external outlook improved in}

2004. The oil price increase, coupled with a pickup in oil export volumes, resulted in a 20 percent rise in oil export revenues (Tables 4 and 5; Figure 4). A sharp improvement in the terms of trade contributed to an increase in the current account balance of about 1 percentage point of GDP. Improved revenues enabled the government to make arrears payments to creditors. The Congo used about 70 percent of the primary fiscal surplus for external debt-service and arrears payments.

\begin{tabular}{|lr|}
\hline \multicolumn{2}{|c|}{ Congo: Effort Toward Normalizing } \\
Creditor Relations, 2004 \\
(In billions of CFA francs)
\end{tabular}

10. The real effective exchange rate (REER) remains about

10-15 percent below its pre-1994 devaluation level despite the secular rise in the terms of trade and the strengthening of the euro (Figure 5). Although the REER seems to be stable, the Congo's external competitiveness suffers from the high cost of doing business and poor governance (see, for 
example, Transparency International corruption perception index, and the World Bank's Doing Business database ${ }^{3}$ ).

\section{The government made progress in 2004 in strengthening governance and} transparency in the oil sector. Particularly noteworthy was the emphasis on Internet publication (www.mefb-cg.org), including of the quarterly oil revenue certifications (Box 2), large parts of the 1999-2001 and 2002 external independent audits of the SNPC, and all active production-sharing agreements. An external audit of the national oil refinery (CORAF) for 2002 was completed in December. The government publicly announced in June 2004 its commitment to adhere to the Extractive Industries Transparency Initiative (EITI).

\section{More information on the extent of deep-rooted structural weaknesses in the} banking, fuel, and energy sectors came to light in early 2005 . Losses in the fuel sector, and arrears of the national electricity company (SNE) vis-à-vis its counterpart in the Democratic Republic of Congo (SNEL) for unpaid electricity bills, amounted to 31/2 percent of GDP at end-2004. The costs of cleaning up the portfolio of a recently privatized bank (LCB, which emerged from the CAIC) and recapitalizing the COFIPA bank are estimated at 0.3 percent of the Congo's 2004 GDP. When the CAIC was privatized in March 2004, the government committed to compensating the new private owners for nonperforming assets, which would be identified by an independent audit of the portfolio.

\section{Program Implementation}

\section{Program implementation under the PRGF arrangement during October 2004- March 2005 was satisfactory, despite expenditure overruns in 2004:}

- Most end-December 2004 quantitative benchmarks were observed. Nonetheless, the primary budget surplus was lower than programmed (adjusted for higher-thanprogrammed oil prices and shipments) by CFAF 55.2 billion. While a small part of the shortfall (CFAF 14 billion) can be attributed to expenditure overruns, the bulk stems from factors beyond the authorities' control, namely the receipt of payments for two oil shipments in January instead of December (CFAF 34.2 billion). Moreover, although the world market price for oil was higher than programmed, raising the (adjusted) primary budget surplus target under the program, the positive revenue impact was mostly offset by the sharp rise in the discount on Congolese heavy oil mentioned earlier.

- Most quantitative criteria for end-March 2005 were met. However, the targets on payments of external arrears at end-December 2004 (quantitative benchmark) and endMarch 2005 (quantitative performance criterion) were missed; the authorities adhered to

\footnotetext{
${ }^{3}$ The websites are http://www.transparency.org/surveys/index.html, and http://rru.worldbank.org/DoingBusiness/ExploreEconomies/BusinessClimateSnapshot.aspx?econ omyid=49.
} 
the December 2004 Paris Club rescheduling agreement, entailing lower-thanprogrammed payments on post-cutoff-date arrears.

\section{Box 2. Lessons from Oil Revenue Certification}

Since 2003, the Congo's oil revenues are being certified by external auditors on a quarterly basis, and the reports are published on the Internet. Of the government's total oil receipts, 80 percent of oil is sold by the SNPC, the rest by private operators. Two verifications are done by the auditors:

- First, they feed actual production and price information into a monthly model for each contract. This allows them to check whether operators are paying royalties and the share of profits owed to the government. The government receives its payments in kind; these are valued at the government's fiscal price. ${ }^{1}$ The auditors noted underpayment of about US\$11 million in the second half of 2004. The authorities are pursuing this with the relevant companies.

- Second, they compare the value of the oil sold with the related treasury cash receipts. This check highlights by how much the SNPC sells the government's oil below the fiscal price 1 — $\$ 1.73 /$ barrel in 2003 and $\$ 2.16 /$ barrel in 2004 - and the high costs of financial transactions associated with the SNPC's sale of government oil-\$0.64/barrel in 2003 and $\$ 0.49 /$ barrel in 2004. The government ascribes SNPC's weak marketing performance to the company's relative newness, as well as to the small scale of its exports.

Forward-looking issues:

- The SNPC's marketing strategy needs strengthening.

- The certifications do not track all financing transactions carried out by the SNPC on behalf of the government, only those that are related to current-period oil revenues. To allay concerns about potential discrepancies related to these transactions, regular reconciliation would be needed between oil receipts identified by the certifications and oil-related transactions recorded in the government's budget operations table. Reconciliation for 2003 and 2004 by an independent audit firm is part of the program.

- With a view to curbing the high costs of financial transactions undertaken by the SNPC for the government, the use of short-term oil advances would eventually need to be limited.

- The certifications do not cover nonrecurrent or incidental payments (bonuses, dividends, or corrections on past payments); nor do they cover the SNPC's equity oil income. These will, however, be covered by the EITI process of parallel reporting of company oil-related payments and government oil receipts.

${ }^{1}$ It is the price adopted by the government at which companies must convert their costs from value into barrels of oil as the basis for the profit oil calculations. 
- Out of the three structural performance criteria for December 2004 and March 2005, two were met: the 2002 external audit of the CORAF and the tracking of quarterly expenditure execution in 2004. The complex audits of the production costs of oil companies were not completed on time (completion of these audits is a prior action for the first review under the PRGF arrangement).

- Most structural benchmarks for December 2004 and March 2005 were observed. Particularly noteworthy was the completion of the SNPC's 2003 external audit and publication of the entire report on the Finance Ministry's website (www.mefb-cg.org). Nonetheless, the government did not commence the quarterly publication of information on oil sector transactions.

\section{The audits of the CORAF and the SNPC revealed weaknesses in these} companies' accounting practices and internal control procedures (Box 3 ). Following the 1999-2001 external audit of the SNPC in 2003, the government adopted an action plan in March 2004. Its implementation became a condition of the World Bank's Economic Recovery Credit (ERC), including the 2002 audit of the CORAF.

\section{Box 3. Key Findings of Recent Audits}

The SNPC's financial accounts are audited yearly, and the authorities are committed to undertaking the 2003-04 audit of the CORAF before the end of 2005.

\section{SNPC audit, 2003}

The audit report - published on the government website - noted serious weaknesses in accounting and internal control. It pointed to inconsistencies between the cash positions shown in the company's accounts on the one hand, and its income statements and balance sheets on the other. Auditors did not have access to information on the company's foreign bank accounts.

The SNPC's top management was replaced in January 2005. In its response to the audit report — which has also been published - the new management team acknowledges the deficiencies and has pledged to address them, including by establishing and monitoring a quarterly action plan to strengthen the SNPC's accounting and internal control.

\section{CORAF audit, 2002}

The audit report - a summary of which was published on the government website - highlights significant weaknesses in accounting and internal control. The company's accounts are not in compliance with Congolese accounting standards and do not present a reliable view of the company's operations and financial situation. Internal controls are weak in view of the absence of systems for calculating and analyzing production costs and for monitoring budget execution, a procurement policy, and an adequate information system. 


\section{REPORT ON THE DISCUSSIONS}

\section{The Congo's medium-term prospects have improved significantly in view of} rising oil prices, notwithstanding the downward revision of oil production. At the same time, new problems identified in the banking, fuel, and electricity sectors could jeopardize fiscal sustainability. The government has adopted a strategy to remedy the related structural weaknesses (MEFP, Section V) while also limiting the budgetary impact, preserving medium-term fiscal sustainability, and maintaining the objective of lowering poverty.

\section{The macroeconomic forecast for 2005-07 was revised relative to the PRGF} scenario to reflect (see text table below) (i) higher oil prices, (ii) lower oil production, (iii) payments of post-cutoff-date arrears, (iv) lower primary expenditures related to a regional project brought forward from 2005 to 2004, (v) higher poverty-related spending, and (vi) higher payments of domestic arrears. The Congo's fiscal position is now stronger, with a higher primary fiscal surplus. Consistent with these targets, the authorities intend to present a 2005 supplementary budget to parliament later in the year.

\begin{tabular}{|c|c|c|c|c|c|c|}
\hline \multicolumn{7}{|c|}{$\begin{array}{l}\text { Congo: Key Macroeconomic Indicators, 2004-07 } \\
\text { (In units indicated) }\end{array}$} \\
\hline & \multicolumn{3}{|c|}{ Baseline Scenario } & \multicolumn{3}{|c|}{ Updated Scenario } \\
\hline & 2004 & 2005 & $\frac{2006-07}{\text { average }}$ & $\begin{array}{r}2004 \\
\text { Est. }\end{array}$ & 2005 & $\begin{array}{r}2006-07 \\
\text { average }\end{array}$ \\
\hline Real GDP growth (in percent) & 4.0 & 9.2 & 4.4 & 3.6 & 9.2 & 3.9 \\
\hline Oil & 2.0 & 17.4 & 2.6 & 0.5 & 16.7 & -1.5 \\
\hline Nonoil & 5.0 & 5.1 & 5.4 & 5.2 & 5.5 & 5.6 \\
\hline \multicolumn{7}{|l|}{ Oil sector parameters } \\
\hline Oil price (Brent, U.S. dollars per barrel) & 37.1 & 37.3 & 34.9 & 38.2 & 47.5 & 42.4 \\
\hline Price rule (U.S. dollars per barrel) 1/ & 36.1 & 33.3 & 30.9 & $\ldots$ & 45.2 & 38.4 \\
\hline Average Congolese price (thousands of CFAF per barrel) 2/ & 18.2 & 16.9 & 15.6 & 18.3 & 19.8 & 17.3 \\
\hline Production (millions of barrels) & 83.3 & 97.9 & 102.2 & 82.1 & 94.7 & 95.3 \\
\hline \multicolumn{7}{|l|}{ Fiscal aggregates (in percent of GDP) } \\
\hline Domestic revenue & 31.0 & 34.0 & 29.6 & 32.2 & 37.7 & 31.7 \\
\hline Of which: Oil revenue & 22.2 & 25.3 & 20.0 & 23.1 & 29.6 & 22.2 \\
\hline Primary expenditures & 20.9 & 20.8 & 21.5 & 21.6 & 20.1 & 21.3 \\
\hline Primary fiscal balance $3 /$ & 10.1 & 13.2 & 8.2 & 10.5 & 17.7 & 10.4 \\
\hline Of which: Nonoil primary fiscal balance 4/ & -24.3 & -24.8 & -22.5 & -25.3 & -26.4 & -23.3 \\
\hline Current account balance (in percent of GDP) & 2.5 & 3.0 & 2.8 & 2.3 & 4.9 & 2.5 \\
\hline \multicolumn{7}{|l|}{ Memorandum items: } \\
\hline Potential oil windfall revenue (in billions of CFAF) $5 /$ & 9.8 & 144.3 & 129.5 & 0.0 & 82.8 & 114.2 \\
\hline \multicolumn{7}{|c|}{ Sources: Congolese authorities, and Fund staff estimates and projections. } \\
\hline $\begin{array}{l}\text { 1/ For the second half of } 2005 \text { and onward, the projection inco } \\
\text { by US } \$ 4 \text { per barrel. } \\
\text { 2/ The average Congolese blend oil price in CFA francs, after } t \\
3 \text { / Revenue (excl. grants) minus noninterest current expenditur } \\
4 \text { / In percent of non-oil GDP. } \\
5 \text { / The projections of oil revenue are done on the basis of the } \\
\text { to additional revenues that would be registered if the full WEO }\end{array}$ & $\begin{array}{l}\text { pruden } \\
\text { ule and } \\
\text { omestic } \\
\text { oil pric } \\
\text { e to ma }\end{array}$ & $\begin{array}{l}\text { factor, sc } \\
\text { er incorp } \\
\text {-finance } \\
\text { minus } \$ 4 \\
\text { ialize. }\end{array}$ & $\begin{array}{l}\text { at the WEC } \\
\text { ting an ave } \\
\text { apital expe } \\
\text { rrel. Estim }\end{array}$ & $\begin{array}{l}\text { ce forec } \\
\text { market } \\
\text { we and } \\
\text { windfal }\end{array}$ & $\begin{array}{l}\text { reduce } \\
\text { unt. } \\
\text { nding. } \\
\text { evenue }\end{array}$ & \\
\hline
\end{tabular}




\section{A. Fiscal Policy}

17. A key objective of the Congo's revised fiscal policy, in view of higher oil prices, is to raise poverty-related spending while still permitting a significant increase in the primary budget surplus (MEFP, Section IV.A). The budget reflects efforts to pursue fiscal consolidation, reduce poverty, and address the problems in the banking, fuel, and energy sectors. Higher revenues will permit a greater surplus, even though expenditures are also being raised. The primary fiscal surplus is projected to be higher than the baseline projection (by 4 $\frac{1}{2}$ percentage points of GDP in 2005 and about 2 percentage points a year during 2006-07). Nonetheless, the fiscal stance (measured in terms of non-oil primary deficit) is somewhat more relaxed during 2005-07 relative to the baseline scenario to accommodate higher spending.

\section{To accelerate progress toward achieving the Millennium Development Goals} (MDGs), poverty-related spending is to increase by 0.9 percent of GDP in 2005 relative to the baseline scenario. The additional resources will be devoted to the priority sectors identified in the I-PRSP. The authorities expressed concerns about achieving the MDGs, except for the eradication of extreme hunger, 100 percent youth literacy, and gender equality (Table 6). Thus, if additional resources were to materialize from oil receipts and debt relief under the enhanced Heavily Indebted Poor Countries Initiative, they favored increasing poverty-related spending even more to achieve other key MDGs. While sharing the authorities' concerns, the staff emphasized that reaching the MDGs would require a multipronged approach, including implementation of business-friendly policies and promotion of productivity-enhancing spending (such as investment in physical and human capital) in a framework that ensures fiscal sustainability and proper tracking of outlays. To ensure effective use of public spending, the authorities plan to prepare a quarterly table with data tracking the various stages of the expenditure process and to accelerate preparations for the introduction of a functional classification of government spending. In addition, they plan to emphasize staff training in the education and health sectors to strengthen absorptive capacity.

19. Under the revised fiscal scenario, the costs stemming from recently identified problems in three sectors will be absorbed after proper validation, but policies are envisaged to limit these costs (MEFP, Section V):

- In the banking sector, the regional banking supervisory agency (COBAC) validated the costs of recapitalizing the COFIPA bank and cleaning up the portfolio of LCB, which was recently privatized; these costs (estimated at 0.3 percent of GDP) have been reflected in the revised macroeconomic scenario in 2005.

- In the fuel sector, the budgetary subsidy will be revised upward by 0.2 percent of GDP relative to the baseline scenario to take account of the rise in world market prices for oil. Subsidies to the sector in the original program entail transfers to the CORAF and subsidization of retail sales of refined petroleum products that are expected to be phased out. 
- In the energy sector, budget allocations will be raised by 0.2 percent of GDP —included in the additional antipoverty spending - to help the SNE pay for electricity procured from the SNEL in the Democratic Republic of Congo.

\section{Total revenues in $\mathbf{2 0 0 5}$ are projected to be higher than programmed by}

3.7 percentage points of GDP, reflecting primarily higher oil prices. The mobilization of oil revenues will be further improved through the strengthening of the quarterly certification process mentioned in Box 2 and the SNPC's improved performance in marketing the government's share of oil production. Non-oil revenue mobilization will benefit from administrative reforms, including measures against fraud and tax evasion, as well as from limits on discretionary tax exemptions.

21. The authorities intend to settle domestic payment arrears transparently and equitably and envisage the preparation of a plan by September 2005. Until this plan is finalized, the program envisages the clearance of social arrears (wages, pensions, and scholarships) but not the settlement of other categories of arrears, notably commercial claims. The budgetary allocations for settling domestic arrears in cash were increased by 0.4 percent of GDP in 2005 and 0.7 percent of GDP in 2006.

\section{Notwithstanding the above revisions, the original program targets through} end-September 2005 are left unchanged, with one exception. The exception relates to the payment of arrears on external debt, revised to reflect the rescheduling agreement with Paris Club creditors on December 16, 2004 and firm pledges from donors for the payment of one-third of the Congo's arrears owed to the AfDB. The acceleration in the last quarter of 2004 of a rural project originally planned for 2005 allows room for more than half of the additional poverty-related spending through September 2005 without changing the original spending target.

23. The use of additional oil revenues — when they materialize — will be guided by the priorities of the original program (see para. 3 of addendum to TMU). These include raising poverty-related outlays, further reducing domestic arrears, settling arrears to external private creditors, and building government deposits in the banking system (which remain very low). Possible increases in poverty-related spending, which would be guided by the priorities set out in the I-PRSP, take into account the sustainability of the fiscal profile. 


\section{B. External Debt}

\section{The Congo is faced with} an unsustainable external debt

(Table 7 and accompanying preliminary document for the Congo's enhanced HIPC Initiative). Its external debt-service burden will continue to be high in 2005 , consuming about 50 percent of the primary fiscal surplus. The authorities stressed their wish for the Congo to reach the decision point under the enhanced HIPC Initiative as soon as feasible. Nonetheless, delays in obtaining data on the SNPC's debts have held up related preparations. Looking forward, the staff stressed the importance of the Congo's performing satisfactorily under the PRGF arrangement, reaching understandings on strong completion point triggers, and resolving outstanding questions on external debt.

\section{The authorities are pursuing efforts to normalize relations with their external} creditors (MEFP, Section IV.C). They plan to conclude agreements with Paris Club creditors in July 2005, and their discussions with official non-Paris Club creditors are well advanced. The Congo also has substantial arrears on commercial debt, about two-thirds of which is owed to London Club creditors. The authorities were in contact with the London Club secretariat in late 2004 and the first half of 2005. A third of the commercial debt (almost US\$900 million) is owed to litigating creditors, many of whom have obtained court judgments in their favor and are seeking to seize the Congo's assets. The authorities have been in contact with some of these creditors. The staff has urged the authorities to use their legal counsel effectively in their dealings with private creditors. The government plans to settle its arrears to private creditors on terms comparable to those expected under the enhanced HIPC Initiative. It has requested World Bank financial assistance for a debtbuyback operation under the IDA facility to allow it to continue addressing the problem of commercial debt. The staff considers the steps taken by the authorities vis-à-vis private external creditors sufficient for meeting the good-faith criterion established under the Fund's policy of lending into arrears. Nonetheless, claims under litigation could pose risks to program financing if litigating creditors are successful in seizing the Congo's assets. 


\section{Structural Reforms and Governance}

26. Key structural reform objectives in the oil sector and public finance management will remain as originally envisaged in the PRGF-supported program (MEFP, Section V). In addition, the government plans to address the new structural challenges that have emerged in the banking, fuel, and energy sectors in order to limit future recourse to the budget, as well as to enhance accountability and transparency.

27. In the banking sector, the government's key objectives are to promote greater market discipline and improve the governance framework as regards bank loans (MEFP, Section IV.B). Near-term measures include intensified surveillance of the COFIPA bank by the COBAC and an audit of the quality of the bank's portfolio. In addition, the bank's restructuring plan will be revised to include the results of the audit and more forceful costcutting measures. The government's goal is to reprivatize the COFIPA without delay through a transparent and competitive bidding process. With regard to the recovery of nonperforming loans, the government will prepare regularly a list of delinquent debtors and circulate it to banks and the treasury - a measure intended to strengthen market discipline.

28. In the fuel sector, key objectives include curtailing losses and reforming the CORAF (MEFP, Section V). Financial losses of the sector are estimated at 1.3 percent of GDP (net of government subsidies) at end-2004; these losses will be validated by an internationally reputable audit firm (MEFP, para 26). To limit future losses: (i) the government will lower margins and raise the prices of jet fuel and gas oil; (ii) the CORAF will adopt a plan to curtail its operating costs; and (iii) the government, in collaboration with the World Bank, will undertake a strategic and economic study of the CORAF, which will lay the groundwork for restructuring the enterprise. To protect the poor from the impact of these reforms in the near term, the retail price of kerosene, a product used heavily by the poor, will not be raised. The government has requested World Bank assistance in conducting a social impact analysis of introducing an automatic price adjustment mechanism in the fuel sector.

29. In the energy sector, reforms are being implemented with technical and financial assistance from the World Bank (MEFP, Section V). Near-term priorities are to improve the SNE's financial situation and its bill collection capabilities. In addition, the SNE had arrears to the SNEL of 1.6 percent of GDP at end-2004; a reconciliation of these arrears is envisaged before the negotiation of a settlement. Over the medium term, efforts to increase domestic energy production will be pursued through the construction of a thermal power plant in Brazzaville, the ongoing construction of a new dam, and the rehabilitation of another dam. A medium-term objective is to improve significantly the sector's bill collection ratio through investment in new meters and other equipment.

\section{The government is resolved to enhance the transparency of natural resource}

management (MEFP, Section V.D). Following the EITI conference in London in March 2005, the Congo was named in a press communiqué as one of nine countries that had made progress in improving transparency in the management of their oil revenues. For 
the period ahead, the government intends to work closely with industry and civil society to implement the EITI objectives. In addition, the government is taking steps to bring the Congo back into the Kimberley Process for the certification of diamonds.

\section{Program Risks}

\section{While the Congo's recent progress provides a good basis for continued program implementation, important risks remain:}

- Security in the Pool region is fragile and will require a successful conclusion to the demobilization program and forthcoming elections.

- Expectations of "peace dividends" and high oil prices mean that pressures to settle domestic arrears will remain high, especially from labor unions and public works contractors.

- Some foreign funds are aggressively seeking to recover the original value of the debt through litigation, which could imply larger-than-expected outlays.

- Reforms have advanced, but there remains a need to further broaden support.

\section{Prior Actions And Program Monitoring}

32. Prior actions for the completion of the first review under the PRGF arrangement are presented in Table 3 of the MEFP, while the program will be monitored on the basis of the quantitative and structural criteria, benchmarks, and indicators shown in Tables 1, 2, and 4 of the MEFP. The program will continue to be monitored through biannual reviews.

\section{Staff Appraisal}

\section{Implementation of the PRGF-supported program during October 2004-} March 2005 was satisfactory, continuing a marked improvement in economic management that began in late 2002. Notwithstanding some expenditure overruns at end2004, most quantitative and structural performance criteria were observed. Particularly noteworthy is the authorities' emphasis on Internet publication of key oil sector information, including of the 2003 audit report of the SNPC. Resolute efforts to further strengthen governance, economic management, and security_along with deepening program ownership — will be critical for the program's success.

\section{The authorities made significant progress in normalizing relations with} external creditors. They have made the critical decision to use a large part of the primary fiscal surplus to clear external arrears to multilateral and Paris Club creditors. This effort, coupled with economic reform implementation, enabled the exceptional treatment by these creditors on debt owed to them. The authorities now need to accelerate good-faith negotiations with the remaining creditors. 
35. In view of rising oil prices the Congo's medium-term prospects have improved significantly, despite the downward revision of oil production. The government needs to adhere to the revised fiscal targets to raise pro-poor spending, avoid procyclical spending, and allow an increase in the primary budget surplus. Priorities for the use of windfall oil revenues, if they materialize, should include further raising poverty-related outlays, reducing domestic arrears, settling arrears with external private creditors, and saving for future generations.

\section{It is regrettable that the extent of deep-rooted structural problems in the} banking, fuel, and energy sectors came to light only in early 2005. The potential costs to the budget stemming from these sectors are large, with risks to the attainment of the poverty reduction objectives under the program. It is commendable, however, that the authorities have resolved to tackle these structural weaknesses to safeguard medium-term fiscal sustainability and address related governance concerns. The envisaged measures are ambitious and require broad political support.

\section{The government's plans to redouble its efforts to implement its poverty} reduction program as envisaged in the I-PRSP are welcome. Increased poverty spending needs to be accompanied by measures to strengthen expenditure tracking, including through the preparation of quarterly tables and the introduction, in due course, of a functional classification of government spending. Given the need to strengthen absorptive capacity, the authorities' intention to expand staff training in education and health is welcome.

38. The staff recommends the completion of the first review under the PRGF arrangement in light of the progress the government has made so far in implementing the program. The staff also supports the authorities' request for waivers of the nonobservance of one quantitative criterion and one structural performance criterion at endMarch 2005, and a modification of one quantitative performance criterion at endSeptember 2005. 
Figure 1. Republic of Congo: Output and Price Development, 1990-2007
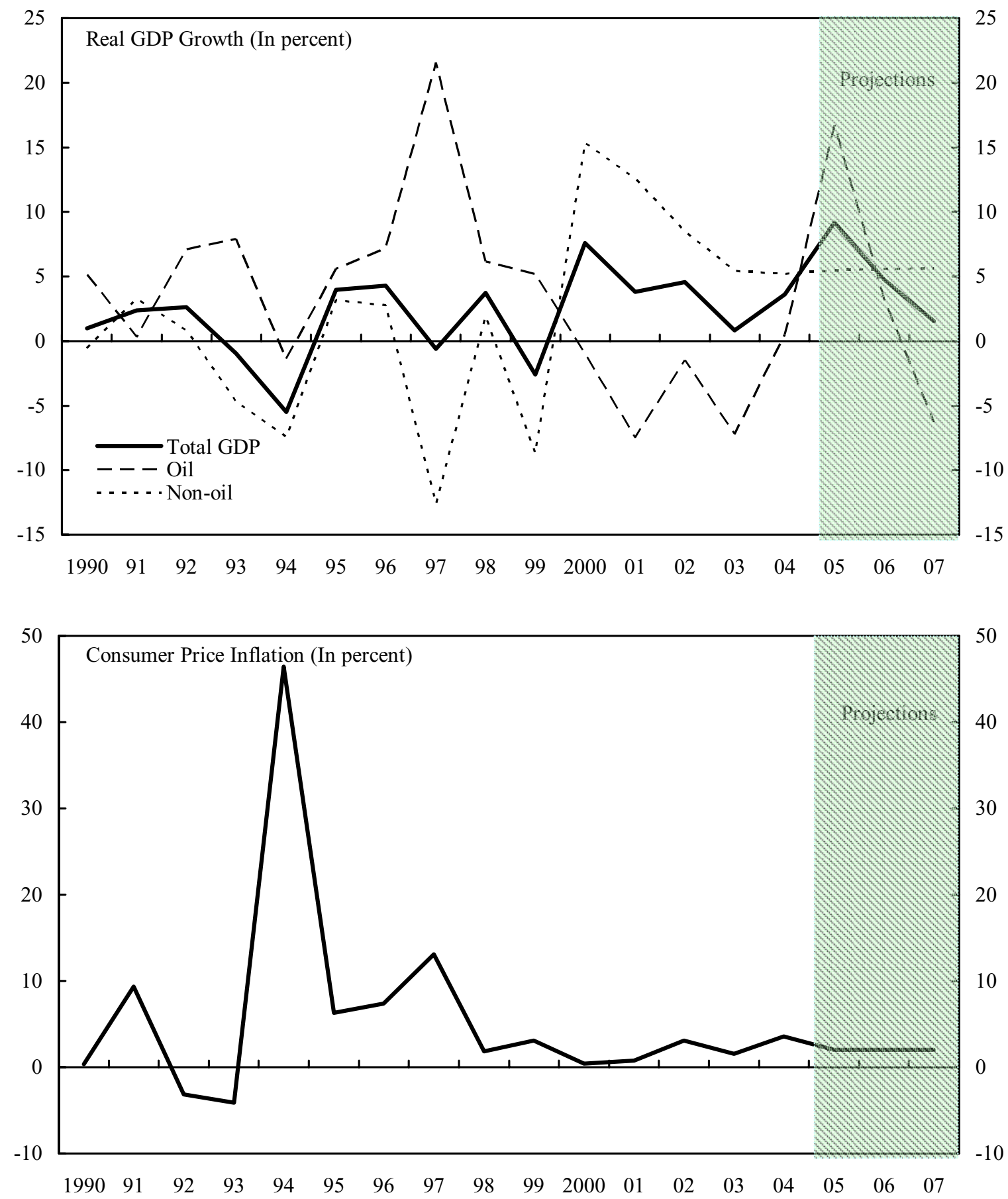

Sources: Congolese authorities; and Fund staff estimates. 
Figure 2. Republic of Congo: Fiscal Developments, 1990-2004
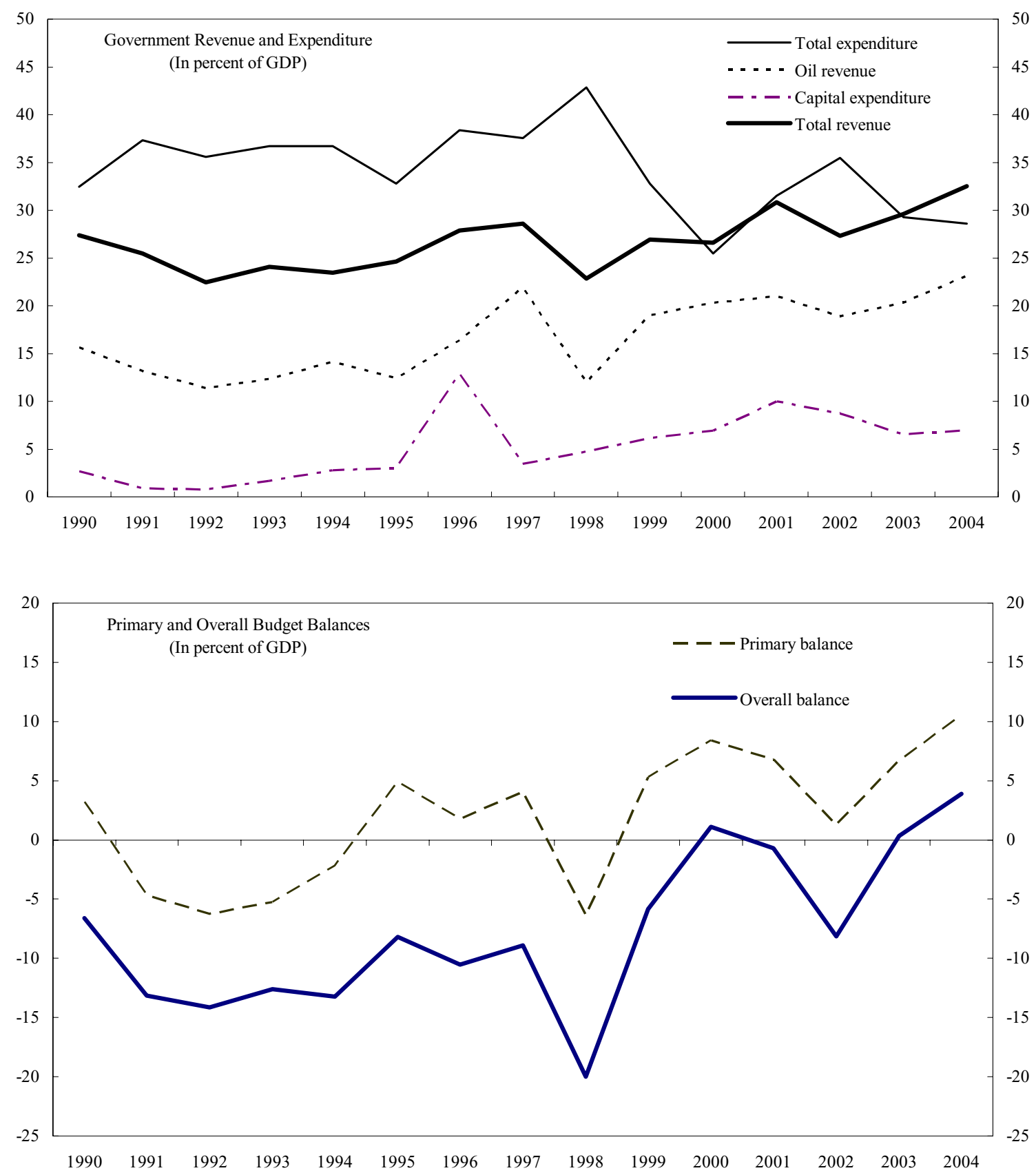

Sources: Congolese authorities; and Fund staff estimates. 
Figure 3. Republic of Congo: Monetary Developments, 1991-2004
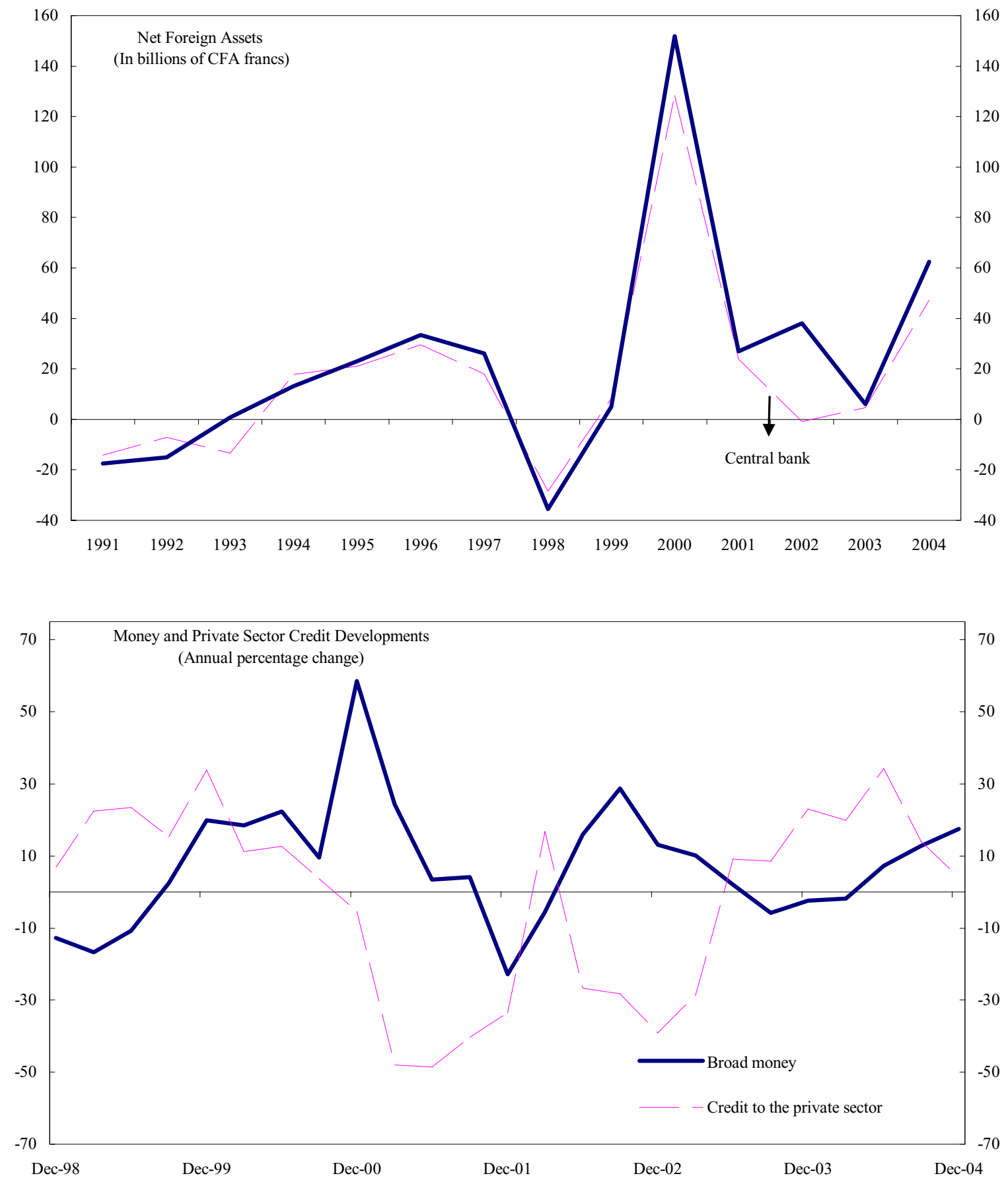

Sources: Congolese authorities; and Fund staff estimates. 
Figure 4. Republic of Congo: External Sector Development, 1990-2004
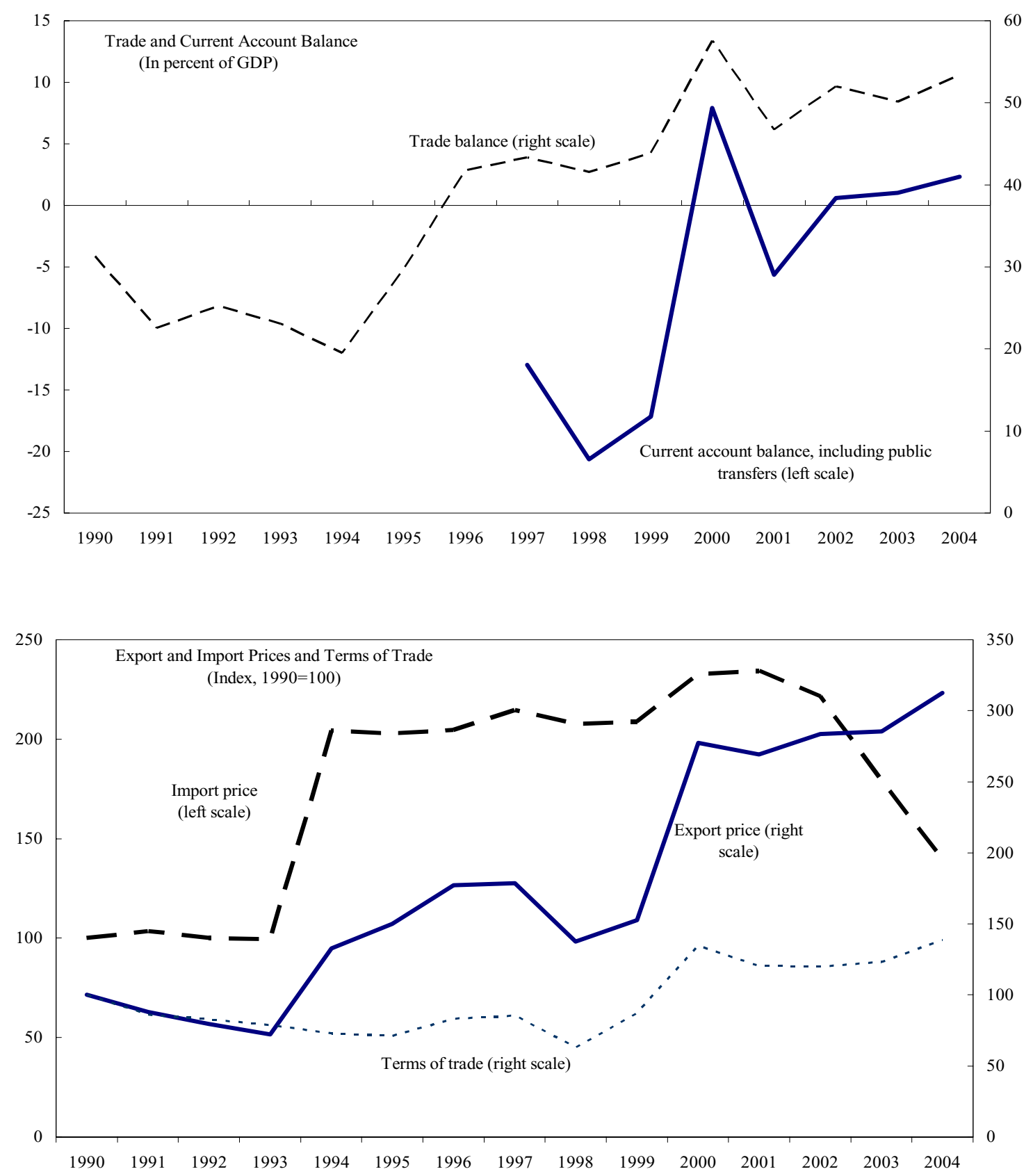

Sources: Congolese authorities; and Fund staff estimates. 


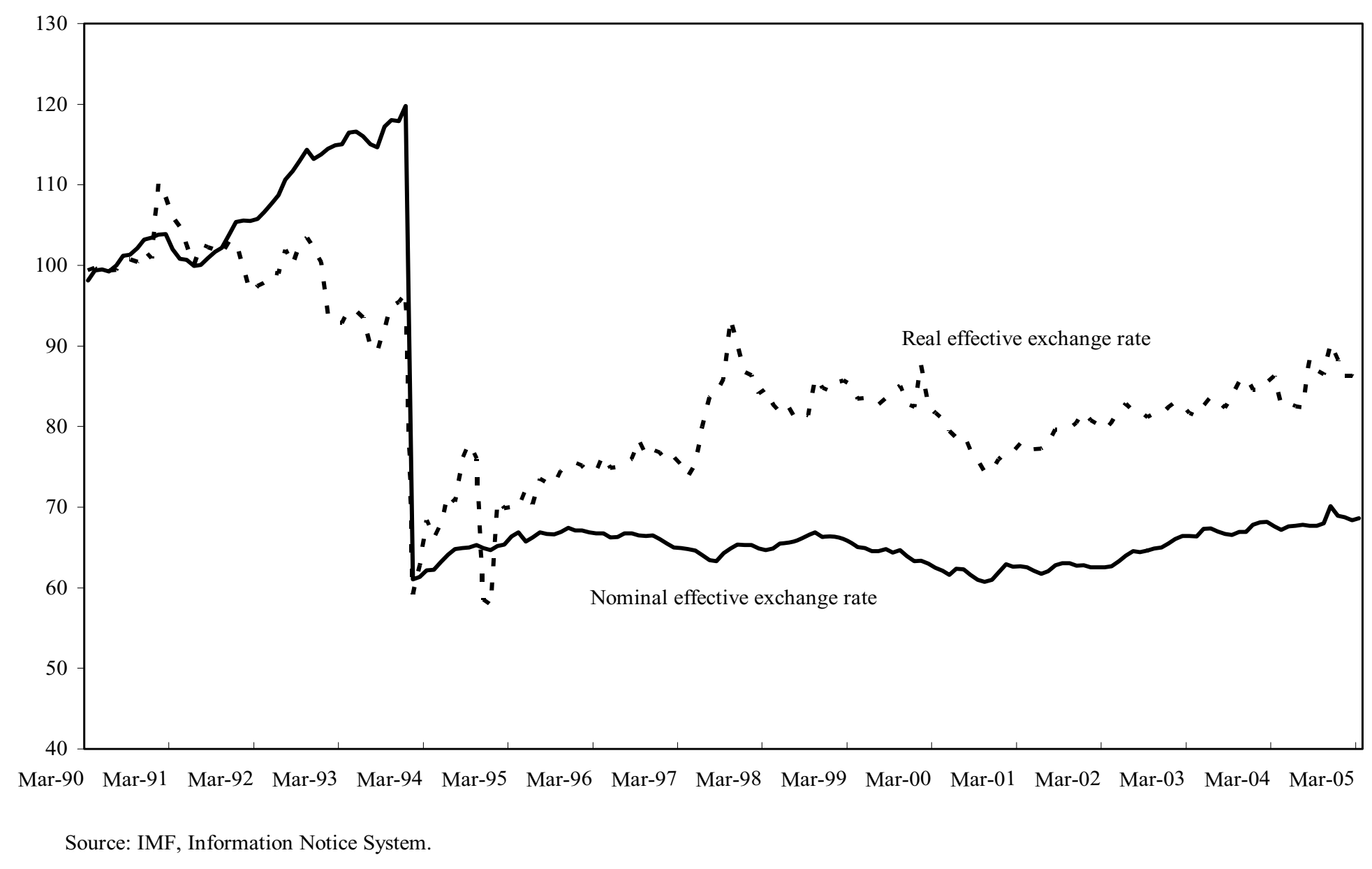


Table 1. Republic of Congo: Selected Economic and Financial Indicators, 2001-07

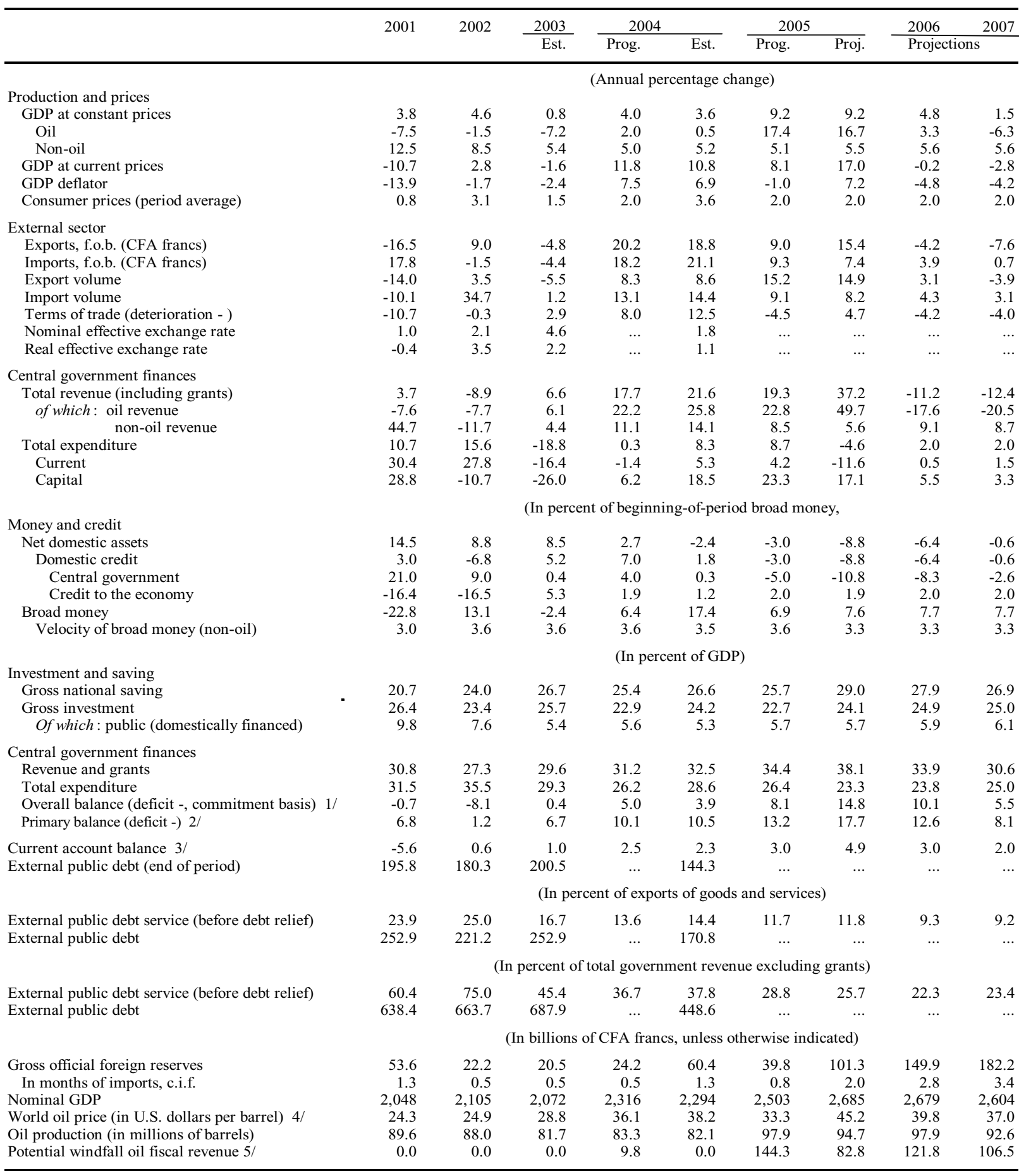

Sources: Congolese authorities; and Fund staff estimates and projections.

$1 /$ Including grants.

2/ Revenue (excluding grants) minus noninterest current expenditure minus domestically financed capital expenditure and net lending.

3 / Including public transfers.

4/ From 2005 onward, world oil price forecasts incorporate a prudence factor. As a result, WEO price forecasts

are reduced by US\$4 per barrel from 2005 onward.

5 / Additional revenue that would be generated by using $W E O$ forecasts for world oil prices, that is, without applying the prudence factor. 
Table 2. Republic of Congo: Central Government Operations, 2001-07

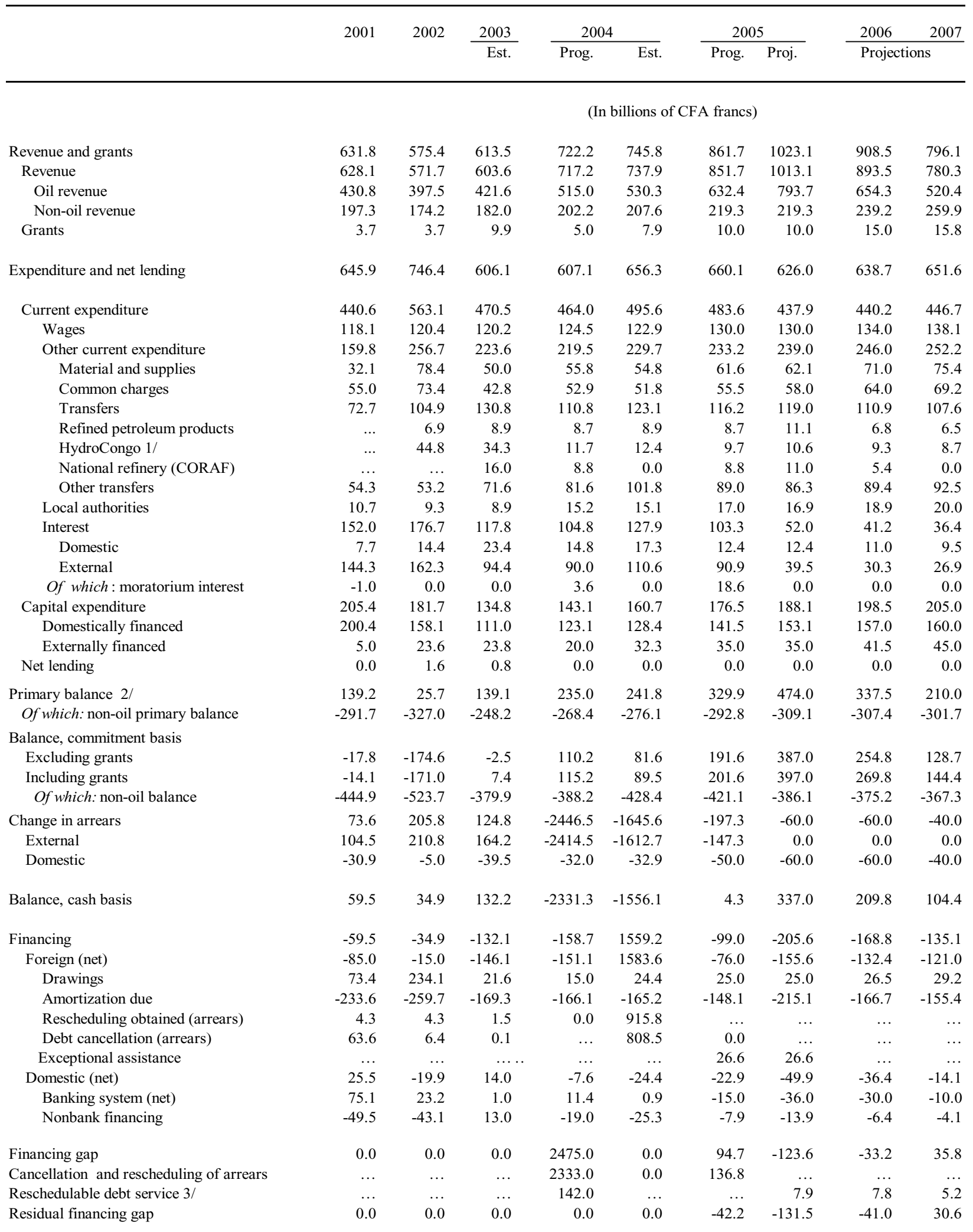


Table 2. Republic of Congo: Central Government Operations, 2001-07 (concluded)

\begin{tabular}{|c|c|c|c|c|c|c|c|c|c|}
\hline & \multirow[t]{2}{*}{2001} & \multirow[t]{2}{*}{2002} & \multirow{2}{*}{$\frac{2003}{\text { Est. }}$} & \multicolumn{2}{|c|}{2004} & \multicolumn{2}{|c|}{2005} & \multirow{2}{*}{\multicolumn{2}{|c|}{$\begin{array}{ll}2006 \quad 2007 \\
\text { Projections }\end{array}$}} \\
\hline & & & & Prog. & $\overline{\text { Est. }}$ & Prog. & Proj. & & \\
\hline & & \multicolumn{8}{|c|}{ (In percent of GDP) } \\
\hline Revenue and grants & 30.8 & 27.3 & 29.6 & 31.2 & 32.5 & 34.4 & 38.1 & 33.9 & 30.6 \\
\hline Revenue & 30.7 & 27.2 & 29.1 & 31.0 & 32.2 & 34.0 & 37.7 & 33.4 & 30.0 \\
\hline Oil revenue & 21.0 & 18.9 & 20.4 & 22.2 & 23.1 & 25.3 & 29.6 & 24.4 & 20.0 \\
\hline Non-oil revenue & 9.6 & 8.3 & 8.8 & 8.7 & 9.0 & 8.8 & 8.2 & 8.9 & 10.0 \\
\hline Total expenditure & 31.5 & 35.4 & 29.2 & 26.2 & 28.6 & 26.4 & 23.3 & 23.8 & 25.0 \\
\hline Primary expenditure & 23.9 & 25.9 & 22.4 & 20.8 & 21.6 & 20.8 & 20.1 & 20.8 & 21.9 \\
\hline of which: pro-poor spending & $\ldots$ & $\ldots$ & 4.0 & 4.7 & 4.5 & 5.8 & 6.1 & $\ldots$ & $\ldots$ \\
\hline Current & 14.1 & 18.4 & 17.0 & 15.5 & 16.0 & 15.2 & 14.4 & 14.9 & 15.8 \\
\hline Wages & 5.8 & 5.7 & 5.8 & 5.4 & 5.4 & 5.2 & 4.8 & 5.0 & 5.3 \\
\hline Other & 8.3 & 12.6 & 11.2 & 10.1 & 10.7 & 10.0 & 9.5 & 9.9 & 10.5 \\
\hline Capital and net lending & 9.8 & 7.6 & 5.4 & 5.3 & 5.6 & 5.7 & 5.7 & 5.9 & 6.1 \\
\hline Interest & 7.4 & 8.4 & 5.7 & 4.5 & 5.6 & 4.1 & 1.9 & 1.5 & 1.4 \\
\hline Foreign-financed capital expenditure & 0.2 & 1.1 & 1.1 & 0.9 & 1.4 & 1.4 & 1.3 & 1.5 & 1.7 \\
\hline Overall balance, commitment basis 4 / & -0.7 & -8.1 & 0.4 & 5.0 & 3.9 & 8.1 & 14.8 & 10.1 & 5.5 \\
\hline Primary balance & 6.8 & 1.2 & 6.7 & 10.1 & 10.5 & 13.2 & 17.7 & 12.6 & 8.1 \\
\hline \multirow[t]{2}{*}{ Of which: non-oil primary balance } & -14.2 & -15.5 & -12.0 & -11.6 & -12.0 & -11.7 & -11.5 & -11.5 & -11.6 \\
\hline & & \multicolumn{8}{|c|}{ (In percent of non-oil GDP) } \\
\hline Non-oil revenue & 22.2 & 17.8 & 17.6 & 18.3 & 19.1 & 18.6 & 18.7 & 18.9 & 19.1 \\
\hline Wages & 13.3 & 12.3 & 11.6 & 11.3 & 11.3 & 11.0 & 11.1 & 10.6 & 10.1 \\
\hline Non-oil primary balance & -32.8 & -33.4 & -24.0 & -24.3 & -25.3 & -24.8 & -26.4 & -24.3 & -22.2 \\
\hline & & \multicolumn{8}{|c|}{ (In billions of CFA francs) } \\
\hline \multicolumn{10}{|l|}{ Memorandum items: } \\
\hline Potential windfall oil revenue 5/ & $\ldots$ & $\ldots$ & $\ldots$ & 9.8 & 0.0 & 144.3 & 82.8 & 121.8 & 106.5 \\
\hline GDP at current market prices & 2048.3 & 2104.9 & 2071.5 & 2315.9 & 2294.3 & 2502.7 & 2685.1 & 2679.0 & 2604.2 \\
\hline Non-oil GDP at market prices & 889.7 & 978.5 & 1035.4 & 1103.3 & 1089.3 & 1179.9 & 1172.6 & 1262.8 & 1360.5 \\
\hline
\end{tabular}

Sources: Ministry of Economy, Finance, and the Budget; and Fund staff estimates and projections.

1/ Excess oil revenue (which arises when operating costs of oil companies are lower than the limits stipulated in

production-sharing agreements) is partly assigned automatically to cover an existing liability (HydroCongo).

2/ Revenue (excluding grants) minus noninterest current expenditure minus domestically financed capital expenditure and net lending.

3/ From 2005 onward, debt service owed to non-Paris Club bilateral creditors and to commercial creditors, excluding oil-collateralized debt.

4/ Including grants.

5/ From 2005 onward, world oil price forecasts incorporate a prudence factor. As a result, $W E O$ price forecasts are reduced by US\$4 per barrel from 2005 onward. 
Table 3. Republic of Congo: Monetary Survey, 2001-05

\begin{tabular}{|c|c|c|c|c|c|c|c|c|c|c|c|c|c|c|c|c|c|}
\hline & \multirow[t]{3}{*}{2001} & \multirow[t]{3}{*}{2002} & \multirow[t]{3}{*}{2003} & \multicolumn{8}{|c|}{2004} & \multicolumn{6}{|c|}{2005} \\
\hline & & & & \multicolumn{2}{|c|}{ Mar. } & \multicolumn{2}{|c|}{ Jun. } & \multicolumn{2}{|c|}{ Sep. } & \multicolumn{2}{|c|}{ Dec. } & \multicolumn{2}{|c|}{ Mar. } & \multirow{2}{*}{\multicolumn{2}{|c|}{$\frac{\text { Jun. } \quad \text { Sep. }}{\text { Program }}$}} & \multicolumn{2}{|c|}{ Dec. } \\
\hline & & & & Proj. & Est. & Proj. & Est. & Proj. & Est. & Prog. & Est. & Prog. & Est. & & & Prog. & Proj. \\
\hline & \multicolumn{17}{|c|}{ (In billions of CFA francs) } \\
\hline Net foreign assets & 26.9 & 38.0 & 6.0 & 6.3 & 13.2 & 6.7 & 40.9 & 28.7 & 48.2 & 16.5 & 62.4 & 24.0 & 76.7 & 31.5 & 39.0 & 46.5 & 117.4 \\
\hline Central bank & 23.9 & -0.9 & 4.6 & 4.9 & 4.6 & 5.3 & -2.0 & 4.7 & 0.9 & 11.4 & 47.3 & 16.9 & 45.9 & 22.4 & 27.9 & 33.4 & 94.3 \\
\hline Deposit money banks & 3.0 & 38.9 & 1.4 & 1.4 & 8.5 & 1.4 & 42.9 & 24.0 & 47.2 & 5.1 & 15.1 & 7.1 & 30.8 & 9.1 & 11.1 & 13.1 & 23.1 \\
\hline Net domestic assets & 231.1 & 253.7 & 278.6 & 287.5 & 252.9 & 263.9 & 250.8 & 284.5 & 260.8 & 286.4 & 271.8 & 287.2 & 241.3 & 288.0 & 288.6 & 277.4 & 242.3 \\
\hline Net domestic credit & 267.2 & 249.7 & 265.0 & 274.0 & 245.4 & 250.3 & 249.4 & 283.1 & 256.6 & 285.0 & 270.1 & 285.8 & 243.7 & 286.6 & 287.2 & 276.0 & 240.6 \\
\hline Net credit to the public sector & 158.2 & 183.3 & 183.3 & 190.9 & 159.2 & 166.0 & 156.0 & 192.9 & 169.2 & 197.9 & 185.1 & 197.2 & 155.7 & 196.4 & 195.6 & 182.9 & 149.0 \\
\hline Net credit to the government & 163.5 & 186.8 & 187.8 & 195.5 & 164.2 & 170.5 & 157.4 & 194.2 & 173.9 & 199.2 & 188.8 & 198.5 & 162.6 & 197.7 & 196.9 & 184.2 & 152.7 \\
\hline Central bank & 160.3 & 173.9 & 182.1 & 187.2 & 168.6 & 172.9 & 181.1 & 183.5 & 177.4 & 188.5 & 173.3 & 187.7 & 164.3 & 187.0 & 186.1 & 173.4 & 152.2 \\
\hline Deposit money banks & 3.2 & 12.8 & 5.8 & 8.3 & -4.5 & -2.3 & -23.7 & 10.8 & -3.4 & 10.8 & 15.5 & 12.6 & -1.7 & 13.1 & 14.8 & 10.8 & -9.5 \\
\hline Claims on public agencies, net & -5.3 & -3.4 & -4.5 & -4.5 & -4.9 & -4.5 & -1.3 & -1.3 & -4.7 & -1.3 & -3.7 & -1.3 & -6.9 & -1.3 & -1.3 & -1.3 & -3.7 \\
\hline Credit to the economy & 109.0 & 66.4 & 81.7 & 83.0 & 86.1 & 84.3 & 93.4 & 90.3 & 87.5 & 87.1 & 85.0 & 88.6 & 88.0 & 90.1 & 91.6 & 93.1 & 91.6 \\
\hline Other items, net & -36.1 & 4.0 & 13.6 & 13.6 & 7.5 & 13.6 & 1.4 & 1.4 & 4.2 & 1.4 & 1.7 & 1.4 & -2.5 & 1.4 & 1.4 & 1.4 & 1.7 \\
\hline Broad money & 258.0 & 291.7 & 284.6 & 293.9 & 266.1 & 270.5 & 291.6 & 313.2 & 309.0 & 302.9 & 334.2 & 311.2 & 318.0 & 319.5 & 327.6 & 323.9 & 359.7 \\
\hline Currency outside banks & 142.9 & 129.0 & 131.9 & 132.4 & 107.1 & 121.9 & 113.8 & 141.1 & 122.9 & 136.4 & 155.9 & 136.2 & 136.3 & 139.9 & 143.4 & 141.8 & 144.1 \\
\hline Demand deposits & 95.2 & 142.2 & 103.2 & 112.2 & 106.5 & 103.3 & 122.0 & 119.7 & 129.7 & 115.7 & 122.9 & 124.9 & 124.1 & 128.2 & 131.5 & 130.0 & 150.2 \\
\hline \multirow[t]{2}{*}{ Time deposits } & 19.9 & 20.5 & 49.4 & 49.2 & 52.4 & 45.3 & 55.8 & 52.4 & 56.4 & 50.7 & 55.4 & 50.1 & 57.6 & 51.4 & 52.7 & 52.1 & 65.5 \\
\hline & \multicolumn{17}{|c|}{ (Changes in percent of beginning-of-year broad money) } \\
\hline Net foreign assets & -37.3 & 4.3 & -11.0 & 0.1 & 2.5 & 0.2 & 12.3 & 8.0 & 14.8 & 3.7 & 19.8 & 2.5 & 4.3 & 5.0 & 7.4 & 9.9 & 16.5 \\
\hline Net domestic assets & 14.5 & 8.8 & 8.5 & 3.1 & -9.0 & -5.2 & -9.8 & 2.1 & -6.2 & 2.7 & -2.4 & 0.3 & -9.1 & 0.5 & 0.7 & -3.0 & -8.8 \\
\hline Net domestic credit & 3.0 & -6.8 & 5.2 & 3.1 & -6.9 & -5.2 & -5.5 & 6.4 & -2.9 & 7.0 & 1.8 & 0.3 & -7.9 & 0.5 & 0.7 & -3.0 & -8.8 \\
\hline Net credit to the government & 21.0 & 9.0 & 0.4 & 2.7 & -8.3 & -6.1 & -10.7 & 2.2 & -4.9 & 4.0 & 0.3 & -0.2 & -7.8 & -0.5 & -0.8 & -5.0 & -10.8 \\
\hline Credit to the economy & -16.4 & -16.5 & 5.3 & 0.5 & 1.5 & 0.9 & 4.1 & 3.0 & 2.0 & 1.9 & 1.2 & 0.5 & 0.9 & 1.0 & 1.5 & 2.0 & 1.9 \\
\hline Broad money & -22.8 & 13.1 & -2.4 & 3.3 & -6.5 & -4.9 & 2.5 & 10.0 & 8.6 & 6.4 & 17.4 & 2.7 & -4.9 & 5.5 & 8.2 & 6.9 & 7.6 \\
\hline \multicolumn{18}{|l|}{ Memorandum items: } \\
\hline \multicolumn{18}{|l|}{ Velocity } \\
\hline Non-oil GDP/average M2 & 3.0 & 3.6 & 3.6 & $\ldots$ & $\ldots$ & $\ldots$ & $\ldots$ & $\ldots$ & 3.6 & 3.6 & 3.5 & $\ldots$ & & $\ldots$ & $\ldots$ & 3.6 & 3.3 \\
\hline Non-oil GDP/end-period M2 & 3.4 & 3.4 & 3.6 & $\ldots$ & $\ldots$ & $\ldots$ & $\ldots$ & $\ldots$ & 3.6 & 3.6 & 3.3 & $\ldots$ & & $\ldots$ & $\ldots$ & 3.6 & 3.3 \\
\hline Total GDP growth & -10.7 & 2.8 & -1.6 & $\ldots$ & $\ldots$ & $\ldots$ & $\ldots$ & $\ldots$ & 5.2 & 11.8 & 10.8 & $\ldots$ & & $\ldots$ & $\ldots$ & 8.1 & 17.0 \\
\hline Non-oil GDP growth & 12.6 & 10.0 & 5.8 & $\ldots$ & $\ldots$ & $\ldots$ & $\ldots$ & $\ldots$ & 6.3 & 6.6 & 5.2 & $\ldots$ & & $\ldots$ & $\ldots$ & 6.9 & 7.6 \\
\hline Credit to the economy/non-oil GDP & 12.2 & 6.8 & 7.9 & . & $\ldots$ & $\ldots$ & $\ldots$ & $\ldots$ & 7.9 & 7.9 & 7.8 & $\ldots$ & & $\ldots$ & $\ldots$ & 7.9 & 7.8 \\
\hline
\end{tabular}

Sources: BEAC; and Fund staff calculations. 
Table 4. Republic of Congo: Balance of Payments, 2001-07

(In billions of CFA francs; unless otherwise indicated)

\begin{tabular}{|c|c|c|c|c|c|c|c|c|c|}
\hline & \multirow[t]{2}{*}{2001} & \multirow[t]{2}{*}{2002} & \multirow{2}{*}{$\frac{2003}{\text { Est. }}$} & \multicolumn{2}{|c|}{2004} & \multicolumn{2}{|c|}{2005} & \multirow{2}{*}{\multicolumn{2}{|c|}{$\begin{array}{l}2006 \quad 2007 \\
\text { Projections }\end{array}$}} \\
\hline & & & & Prog. & $\overline{\text { Est. }}$ & Prog. & Proj. & & \\
\hline Current account & -115 & 12 & 21 & 59 & 54 & 75 & 131 & 80 & 51 \\
\hline Trade balance & 957 & 1,095 & 1,039 & 1,218 & 1,225 & 1,326 & 1,458 & 1,346 & 1,191 \\
\hline Exports, f.o.b. & 1,456 & 1,587 & 1,510 & 1,774 & 1,794 & 1,933 & 2,070 & 1,983 & 1,831 \\
\hline Oil sector & 1,341 & 1,374 & 1,237 & 1,478 & 1,502 & 1,626 & 1,804 & 1,680 & 1,501 \\
\hline Non-oil sector & 115 & 213 & 273 & 295 & 292 & 307 & 266 & 303 & 330 \\
\hline Imports, f.o.b. & -499 & -492 & -471 & -556 & -570 & -607 & -612 & -636 & -641 \\
\hline Oil sector & -179 & -70 & -73 & -100 & -98 & -105 & -121 & -131 & -123 \\
\hline Government & -123 & -108 & -80 & -87 & -99 & -108 & -111 & -116 & -118 \\
\hline Non-oil private sector & -197 & -314 & -317 & -369 & -373 & -394 & -380 & -390 & -399 \\
\hline Balance of services & -463 & -514 & -509 & -600 & -601 & -643 & -721 & -718 & -659 \\
\hline Income & -611 & -571 & -513 & -565 & -576 & -612 & -609 & -552 & -485 \\
\hline Labor income & -19 & -22 & -13 & -20 & -19 & -22 & -25 & -24 & -20 \\
\hline Investment income & -592 & -549 & -500 & -546 & -556 & -590 & -584 & -528 & -464 \\
\hline Of which: interest on public debt & -144 & -162 & -94 & -90 & -108 & -91 & -40 & -30 & -27 \\
\hline Current transfers (net) & 2 & 3 & 4 & 6 & 6 & 4 & 4 & 4 & 4 \\
\hline Private & -2 & -2 & -1 & 0 & 0 & -1 & -1 & -1 & -1 \\
\hline Public & 4 & 4 & 4 & 5 & 5 & 5 & 5 & 5 & 5 \\
\hline Capital account & 69 & 11 & 11 & 6 & 818 & 11 & 11 & 16 & 17 \\
\hline Official grants & 4 & 4 & 10 & 5 & 8 & 10 & 10 & 15 & 16 \\
\hline Debt cancellation & 64 & 6 & 0 & 0 & 809 & 0 & 0 & 0 & 0 \\
\hline Other & 2 & 1 & 1 & 1 & 1 & 1 & 1 & 1 & 1 \\
\hline Financial account & -117 & 68 & 534 & $-2,533$ & -829 & -158 & 28 & -12 & -71 \\
\hline Direct investment (net) & 150 & 164 & 207 & 305 & 297 & 290 & 337 & 356 & 329 \\
\hline Of which: oil sector & 152 & 148 & 151 & 251 & 243 & 240 & 273 & 286 & 264 \\
\hline Portfolio investment & -5 & -6 & -4 & -5 & -5 & -5 & -5 & -4 & -5 \\
\hline Other investment & -262 & -90 & 330 & $-2,833$ & $-1,121$ & -444 & -305 & -364 & -395 \\
\hline Medium and long term & -207 & 147 & 516 & $-2,656$ & -928 & -222 & -298 & -245 & -219 \\
\hline Public sector & -44 & 229 & 598 & $-2,565$ & -836 & -123 & -190 & -140 & -126 \\
\hline Drawings & 73 & 234 & 22 & 15 & 24 & 25 & 25 & 27 & 29 \\
\hline Project & 1 & 20 & 14 & 15 & 24 & 25 & 25 & 27 & 29 \\
\hline Program & 28 & 0 & 8 & 0 & 0 & 0 & 0 & 0 & 0 \\
\hline Amortization & -234 & -260 & -175 & -166 & -165 & -148 & -215 & -167 & -155 \\
\hline Net change in arrears & 104 & 250 & 750 & $-2,414$ & $-1,613$ & 0 & 0 & 0 & 0 \\
\hline Debt rescheduling & 12 & 4 & 1 & 0 & 917 & 0 & 0 & 0 & 0 \\
\hline Private sector & -162 & -82 & -82 & -91 & -91 & -99 & -108 & -105 & -93 \\
\hline Oil & -158 & -77 & -69 & -83 & -84 & -91 & -101 & -94 & -84 \\
\hline Non-oil & -4 & -5 & -13 & -8 & -7 & -8 & -7 & -10 & -9 \\
\hline Short term & -55 & -237 & -186 & -177 & -193 & -222 & -6 & -119 & -176 \\
\hline Errors and omissions & 59 & -116 & -560 & 0 & 0 & 0 & 0 & 0 & 0 \\
\hline Overall balance of payments & -104 & -25 & 5 & $-2,468$ & 43 & -73 & 171 & 84 & -3 \\
\hline Financing & 104 & 25 & -5 & -7 & -43 & -22 & -47 & -51 & -32 \\
\hline Reserve financing & 104 & 25 & -5 & -7 & -43 & -22 & -47 & -51 & -32 \\
\hline IMF (net) & -1 & -6 & -5 & -6 & -6 & -6 & -6 & -2 & 0 \\
\hline Purchases & 0 & 0 & 0 & 0 & 0 & 0 & 0 & 0 & 0 \\
\hline Repurchases & -1 & -6 & -5 & -6 & -6 & -6 & -6 & -2 & 0 \\
\hline Other reserves & 105 & 31 & 0 & 0 & -37 & -16 & -41 & -49 & -32 \\
\hline Financing gap & 0 & 0 & 0 & 2,475 & 0 & 95 & -124 & -33 & 36 \\
\hline \multicolumn{10}{|l|}{ Memorandum items: } \\
\hline Current account balance 1 / & -5.6 & 0.6 & 1.0 & 2.5 & 2.3 & 3.0 & 4.9 & 3.0 & 2.0 \\
\hline Export volume 2/ & -14.0 & 3.5 & -5.5 & 8.3 & 8.6 & 15.2 & 14.9 & 3.1 & -3.9 \\
\hline Import volume $2 /$ & -10.1 & 34.7 & 1.2 & 13.1 & 14.4 & 9.1 & 8.2 & 4.3 & 3.1 \\
\hline Export price 2/ & -10.1 & -2.4 & -4.3 & 9.1 & 16.7 & -3.5 & 0.8 & -5.5 & -4.7 \\
\hline Import price $2 /$ & 0.7 & -2.1 & -7.0 & 1.0 & 3.8 & 1.1 & -3.8 & -1.4 & -0.7 \\
\hline Terms of trade $2 /$ & -10.7 & -0.3 & 2.9 & 8.0 & 12.5 & -4.5 & 4.7 & -4.2 & -4.0 \\
\hline
\end{tabular}

Sources: BEAC; and Fund staff estimates and projections.

1/ In percent of GDP

2/ Annual percentage change. 
Table 5. Republic of Congo: Key Oil Sector Indicators, 2000-07

\begin{tabular}{|c|c|c|c|c|c|c|c|c|c|c|}
\hline & \multirow[t]{2}{*}{2000} & \multirow[t]{2}{*}{2001} & \multirow[t]{2}{*}{2002} & \multirow{2}{*}{$\frac{2003}{\text { Est. }}$} & \multicolumn{2}{|c|}{2004} & \multicolumn{2}{|c|}{2005} & \multirow{2}{*}{\multicolumn{2}{|c|}{$\begin{array}{ll}2006 & 2007 \\
\text { Projections }\end{array}$}} \\
\hline & & & & & Proj. & Est. & Prog. & Proj. & & \\
\hline \multicolumn{11}{|l|}{ Price (in US\$ per barrel, unless otherwise indicated) } \\
\hline \multicolumn{11}{|l|}{ Brent } \\
\hline International price $1 /$ & 28.4 & 24.3 & 24.9 & 28.8 & 37.1 & 38.3 & 37.3 & 47.5 & 43.8 & 41.0 \\
\hline Price rule $2 /$ & $\ldots$ & $\ldots$ & & & 36.1 & $\ldots$ & 33.3 & 45.2 & 39.8 & 37.0 \\
\hline Average Congolese blends & 26.0 & 22.0 & 23.3 & 27.2 & 33.8 & 34.7 & 31.1 & 39.4 & 35.7 & 33.5 \\
\hline Discount for Congolese blends & 2.4 & 2.3 & 1.7 & 1.6 & 2.3 & 3.6 & 2.1 & 5.7 & 4.0 & 3.5 \\
\hline Brent (in thousands of CFA francs per barrel) & 18.5 & 16.1 & 16.2 & 16.8 & 19.3 & 20.2 & 18.1 & 22.6 & 19.9 & 18.5 \\
\hline Production (in millions of barrels) & 96.8 & 89.6 & 88.0 & 81.7 & 83.3 & 82.1 & 97.9 & 94.7 & 97.9 & 92.6 \\
\hline Crude & 92.4 & 85.4 & 84.0 & 78.4 & 80.4 & 79.2 & 94.5 & 91.7 & 93.8 & 90.2 \\
\hline Natural gas & 4.4 & 4.2 & 4.0 & 3.3 & 3.0 & 2.8 & 3.3 & 3.0 & 4.1 & 2.4 \\
\hline Government revenue (in billions of CFA francs) 3/ & 468.1 & 430.8 & 395.7 & 407.3 & 517.0 & 532.4 & 635.4 & 796.7 & 658.3 & 525.4 \\
\hline Regular & 466.2 & 430.1 & 391.9 & 399.4 & 510.7 & 526.1 & 632.4 & 793.7 & 654.3 & 520.4 \\
\hline Of which: marketed by SNPC 4/ & 164.8 & 270.5 & 193.6 & 266.0 & 405.2 & 415.8 & 509.8 & 656.2 & & \\
\hline Bonus & 1.9 & 0.7 & 3.7 & 6.2 & 4.3 & 4.3 & 0.0 & 0.0 & 0.0 & 0.0 \\
\hline Dividends & 0.0 & 0.0 & 0.0 & 1.7 & 2.0 & 2.0 & 3.0 & 3.0 & 4.0 & 5.0 \\
\hline \multicolumn{11}{|l|}{ Percent of gross sales } \\
\hline Government revenue, regular & 36.0 & 33.2 & 30.3 & 31.4 & 33.1 & 35.0 & 36.9 & 42.4 & 37.5 & 33.6 \\
\hline \multicolumn{11}{|l|}{ Memorandum items: } \\
\hline Gross sales (in billions of CFA francs) & $1,295.3$ & $1,295.3$ & $1,295.3$ & $1,295.3$ & $1,555.2$ & $1,501.4$ & $1,713.1$ & $1,870.7$ & $1,745.8$ & $1,548.8$ \\
\hline Potential windfall revenue (in billions of CFA francs) 5/ & $\ldots$ & $\ldots$ & $\ldots$ & $\ldots$ & 9.8 & 0.0 & 144.3 & 82.8 & 121.8 & 106.5 \\
\hline
\end{tabular}

Sources: Congolese authorities; and Fund staff estimates and calculations.

1/ IMF, WEO, March 2005.

2/ Base for projecting the price of Congolese blends and government revenues. From 2005 onward, world oil price

forecasts incorporate a prudence factor. As a result, WEO price forecasts are reduced by US\$4 per barrel from 2005 onward.

3/ Oil revenues in the fiscal table include "Transfers to CORAF" and "Bonuses", and exclude "Dividends" (included in non-oil revenue).

4/ Oil marketed by SNPC on behalf of the state.

5/ Additional revenue that would be generated by using WEO forecasts for world oil prices, that is, without applying the prudence factor. 
Table 6. Republic of Congo: Millennium Development Goals, 1990-2015

Target 1: Halve, between 1990 and 2015, number of people earning less than US\$ 1 a day.
1. Population below US\$1 a day (in percent)
2. Poverty gap ratio at US\$1 a day (in percent)
3. Share of income or consumption held by poorest 20 percent (in percent)

Target 2: Halve, between 1990 and 2015, the proportion of people suffering from hunger.

4. Prevalence of child malnutrition (in percent of children under 5)

5. Population below minimum level of dietary energy consumption (in percent)

\section{Goal 2. Achieve universal primary education}

Target 3: Ensure that, by 2015, children will be able to complete a full course of primary schooling.

6. Net primary enrollment ratio (percent of relevant age group)

7. Cohort reaching grade 5 (in percent)

8. Youth literacy rate (in percent, ages 15-24)

\section{Goal 3. Promote gender equality and empower women}

Target 4: Eliminate gender disparity in primary and secondary education, preferably by 2005 , and all levels of education by 2015 .

9. Ratio of girls to boys in primary and secondary education (in percent)

10. Ratio of young literate females to males (in percent, ages 15-24)

11. Share of women employed in the nonagricultural sector (in percent)

12. Proportion of seats held by women in the national parliament (in percent)

\section{Goal 4. Reduce child mortality}

Target 5: Reduce by two-thirds, between 1990 and 2015, the under-5 mortality rate.

13. Under-5 mortarlity rate (per 1,000 )

14. Infant mortality rate (per 1,000 live births)

15. Immunization against measles (percent of children under 12 months)

Goal 5. Improve maternal death

Target 6: Reduce by three-fourths, between 1990 and 2015, maternal mortality.

16. Maternal mortality ratio (modeled estimate, per 100,000 live births)

17. Proportion of births attended by skilled health personnel (\% of total)

Goal 6. Combat HIV/AIDS, malaria, and other diseases

Target 7: Halt by 2015, and begin to reverse, the spread of HIV/AIDS.

18. HIV prevalence among females (in percent, ages 15-24)

19. Contraceptive prevalence rate (percent of women ages 15-49)

20. Number of children orphaned by HIV/AIDS

Target 8: Halt by 2015 , and begin to reverse, the incidence of malaria and other major diseases.

21. Prevalence of death associated with malaria

22. Share of population in malaria risk areas using effective prevention and treatment

23. Incidence of tuberculosis (per 100,000 people)

24. Tuberculosis cases detected under DOTS (in percent) 
Table 6. Republic of Congo: Millennium Development Goals, 1990-2015 (concluded)

\begin{tabular}{|c|c|c|c|c|c|}
\hline & 1990 & 1995 & 2001 & 2002 & $\begin{array}{r}2015 \\
\text { Target }\end{array}$ \\
\hline \multicolumn{6}{|l|}{ Goal 7. Ensure environmental sustainability } \\
\hline \multicolumn{6}{|c|}{$\begin{array}{l}\text { Target 9: Integrate the principles of sustainable development into policies and } \\
\text { programs. Reverse the loss of environmental resources. }\end{array}$} \\
\hline 25. Forest area (percent of total land area) & 65.1 & $\ldots$ & 64.6 & $\cdots$ & \\
\hline 26. Nationality protected areas (percent of total land area) & & 4.5 & 4.5 & 5.0 & \\
\hline 27. GDP per unit of energy use (PPP \$ per kg oil equivalent) & 1.7 & 2.7 & 3.3 & $\ldots$ & \\
\hline $\begin{array}{l}\text { 28. } \mathrm{CO} 2 \text { emissions (metric tons per capita) } \\
\text { 29. Proportion of population using solid fuels }\end{array}$ & 0.9 & 0.7 & 0.8 & $\cdots$ & \\
\hline \multicolumn{6}{|c|}{ Target 10: Halve by 2015 proportion of people without access to safe drinking water. } \\
\hline 30. Access to improved water source (percent of population) & $\ldots$ & $\ldots$ & 51.0 & $\ldots$ & \\
\hline \multicolumn{6}{|c|}{$\begin{array}{l}\text { Target 11: Achieve by } 2020 \text { significant improvement for at least } 100 \text { million slum } \\
\text { dwellers. }\end{array}$} \\
\hline 31. Access to improved sanitation (percent of population) & $\ldots$ & $\ldots$ & 14.0 & $\ldots$ & \\
\hline 32. Access to secure tenure (percent of population) & $\cdots$ & $\cdots$ & $\cdots$ & $\cdots$ & \\
\hline \multicolumn{6}{|l|}{ Goal 8. Develop a Global Partnership for Development } \\
\hline \multicolumn{6}{|l|}{ Target 16. Develop and implement strategies for productive work for youth. } \\
\hline 45. Unemployment rate of population ages 15-24 (total) & $\ldots$ & $\ldots$ & $\ldots$ & $\ldots$ & \\
\hline \multicolumn{6}{|l|}{ Target 17: Provide access to affordable essential drugs. } \\
\hline 46. Population with access to affordable essential drugs (in percent) & $\ldots$ & $\ldots$ & $\ldots$ & $\ldots$ & \\
\hline \multicolumn{6}{|l|}{$\begin{array}{l}\text { Target 18: Make available new technologies, especially information and } \\
\text { communications. }\end{array}$} \\
\hline $\begin{array}{l}\text { 47. Fixed-line and mobile telephones (per } 1,000 \text { people) } \\
\text { 48. Personal computers (per } 1000 \text { people) }\end{array}$ & $\ldots$ & 8.6 & 55.3 & $\ldots$ & \\
\hline 48. Personal computers (per 1,000 people) & $\ldots$ & $\ldots$ & 3.9 & $\ldots$ & \\
\hline
\end{tabular}

Sources: World Bank; and Fund staff estimates.

Note: Targets 12-15 and indicators 22-44 are excluded because they cannot be measured on a country-specific basis. These are related to official development assistance, market access, and the HIPC Initiative. 
Table 7. Republic of Congo: External Debt, end-2003.

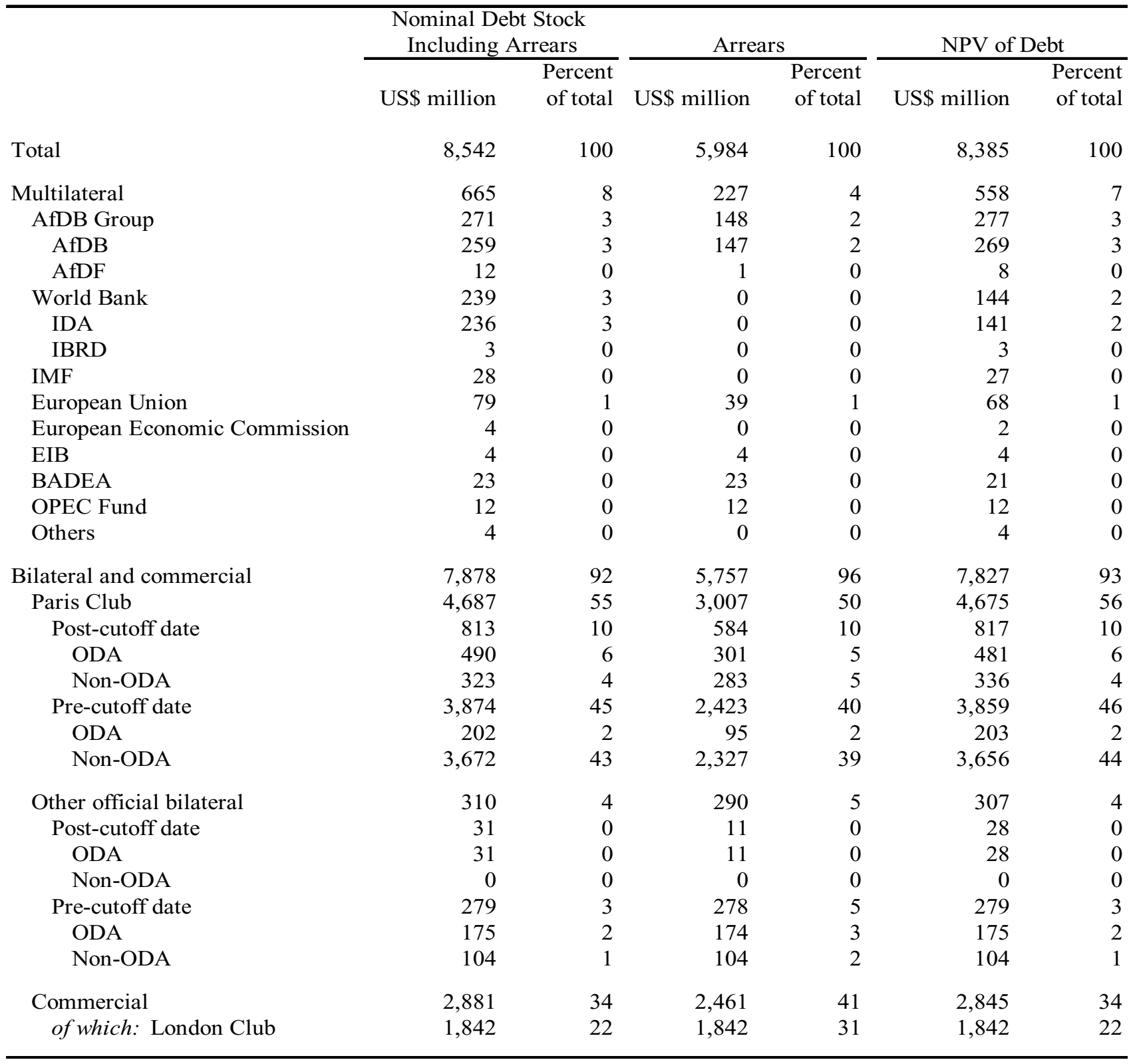

Sources: Congolese authorities; and Fund and Bank staff estimates. 
Table 8. Republic of Congo: Elements of the Capacity to Pay External Debt, 2003-07

(In billions of CFA Francs, unless otherwise indicated)

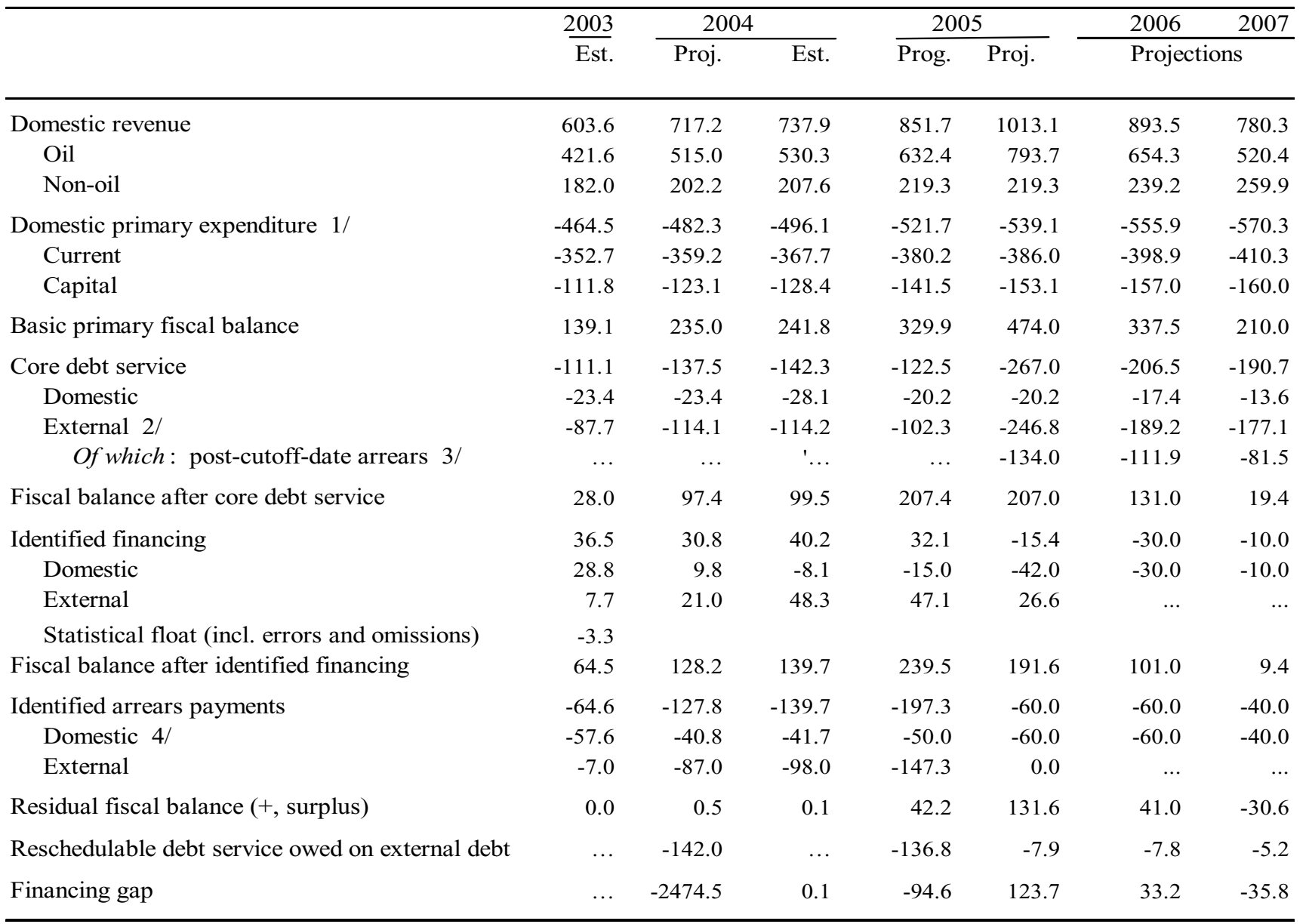

Sources: Congolese authorities; and Fund staff estimates and projections.

1/ Excluding interest payments and foreign-financed investment.

2/ In 2004, core debt service comprises only debt service owed on post-cutoff-date debt to Paris Club creditors and to multilateral creditors, and on oil-collateralized debt; from 2005 onward, it includes all debt service owed to the Paris Club. Club.

3/ Payments due on consolidated arrears related to post-cutoff-date debt to Paris Club creditors.

4/ Related to wages and pensions, as well as to small and medium enterprises. 
Table 9. Republic of Congo: External Financing Requirements, 2001-07 (In billions of CFA Francs)

\begin{tabular}{|c|c|c|c|c|c|c|c|}
\hline & 2001 & 2002 & 2003 & 2004 & 2005 & 2006 & 2007 \\
\hline & & & Est. & \multicolumn{4}{|c|}{ Projections } \\
\hline Requirements & 189.9 & 342.6 & 723.5 & 159.5 & 135.2 & 141.8 & 141.6 \\
\hline Current account excluding official transfers & 119.3 & -8.1 & -16.5 & -48.3 & -126.9 & -75.5 & -46.1 \\
\hline Debt amortization & 233.6 & 259.7 & 174.5 & 165.2 & 215.1 & 166.7 & 155.4 \\
\hline Change in net foreign assets (increase, + ) $1 /$ & -105.3 & -30.8 & 0.3 & 36.7 & 41.0 & 48.5 & 32.4 \\
\hline Errors and omissions & -58.6 & 115.7 & 560.0 & 0.0 & 0.0 & 0.0 & 0.0 \\
\hline Resources & 189.9 & 342.6 & 723.5 & 159.5 & 135.2 & 141.8 & 141.6 \\
\hline Official transfers & 4.2 & 4.4 & 4.3 & 5.3 & 4.6 & 4.7 & 4.7 \\
\hline Official project grants & 5.6 & 4.4 & 11.1 & 9.1 & 11.0 & 16.2 & 16.9 \\
\hline Long-term public loan disbursements & 73.4 & 234.1 & 21.6 & 24.4 & 25.0 & 26.5 & 29.2 \\
\hline Program & 28.0 & 0.0 & 7.7 & 0.0 & 0.0 & 0.0 & 0.0 \\
\hline Project & 1.3 & 20.0 & 13.9 & 24.4 & 25.0 & 26.5 & 29.2 \\
\hline Oil-colllateralized borrowing & 44.1 & 214.1 & 0.0 & 0.0 & 0.0 & 0.0 & 0.0 \\
\hline Private capital (net) & -72.9 & -161.2 & -64.7 & 7.2 & 218.2 & 127.7 & 54.9 \\
\hline Debt relief & 75.2 & 10.6 & 1.5 & 1726.2 & 0.0 & 0.0 & 0.0 \\
\hline Use of IMF resources & 0.0 & 0.0 & 0.0 & 0.0 & 0.0 & 0.0 & 0.0 \\
\hline Change in arrears (increase, + ) & 104.5 & 250.3 & 749.7 & -1612.7 & 0.0 & 0.0 & 0.0 \\
\hline Financing gap & 0.0 & 0.0 & 0.0 & 0.0 & -123.5 & -33.3 & 35.8 \\
\hline \multicolumn{8}{|l|}{ Memorandum item: } \\
\hline Exchange rate: CFA francs per U.S. dollar (average) & 733.0 & 697.0 & 580.1 & 527.6 & $\ldots$ & $\ldots$ & $\ldots$ \\
\hline
\end{tabular}

Sources: Congolese authorities; and Fund staff estimates and projections.

1/ Excluding the change in the net position vis-à-vis the Fund. 
Table 10. Republic of Congo: Proposed Schedule of Disbursements Under the PRGF Arrangement, 2004-07

Amount Date Conditions for disbursement 1/

SDR 7,860,000 December $2004 \quad$ Executive Board approval of the three-year arrangement under the PRGF.

SDR 7,860,000 August 2005

Observance of the performance criteria for March 2005 and completion of the first review under the PRGF arrangement.

SDR 7,860,000 February 2006

Observance of the performance criteria for September 2005 and completion of the second review under the PRGF arrangement.

SDR 7,860,000 July 2006

Observance of the performance criteria for March 2006 and completion of the third review under the PRGF arrangement.

SDR 7,860,000

January 2007

Observance of the performance criteria for September 2006 and completion of the fourth review under the PRGF arrangement.

SDR 7,860,000

July 2007

Observance of the performance criteria for March 2007 and completion of the fifth review under the PRGF arrangement.

SDR 7,830,000 December $2007 \quad$ Observance of the performance criteria for September 2007 and completion of the sixth review under the PRGF arrangement.

1/ Other than the generally applicable conditions for the Poverty Reduction and Growth Facility (PRGF) arrangement. 
Table 11. Republic of Congo: Fund Position, 2004-17

\begin{tabular}{|c|c|c|c|c|c|c|c|c|c|c|c|c|c|c|}
\hline & 2004 & 2005 & 2006 & 2007 & 2008 & 2009 & 2010 & 2011 & 2012 & 2013 & 2014 & 2015 & 2016 & 2017 \\
\hline & \multicolumn{14}{|c|}{ (In millions of SDR) } \\
\hline Total net use of IMF resources & -0.5 & -1.0 & 12.6 & 23.0 & -0.5 & -0.5 & -2.0 & -4.4 & -7.5 & -11.4 & -11.3 & -9.6 & -7.1 & -3.9 \\
\hline Purchases and loans (2004 PRGF arrangement) & 7.9 & 7.9 & 15.7 & 23.5 & & $\ldots$ & $\ldots$ & $\ldots$ & & $\ldots$ & & $\ldots$ & $\ldots$ & \\
\hline Repayments & -8.3 & -8.9 & -3.1 & -0.4 & -0.5 & -0.5 & -2.0 & -4.4 & -7.5 & -11.4 & -11.3 & -9.6 & -7.1 & -3.9 \\
\hline Principal & -8.1 & -8.3 & -2.8 & 0.0 & 0.0 & 0.0 & -1.6 & -3.9 & -7.1 & -11.0 & -11.0 & -9.4 & -7.1 & -3.9 \\
\hline Interest and charges & -0.3 & -0.5 & -0.3 & -0.4 & -0.5 & -0.5 & -0.5 & -0.5 & -0.4 & -0.4 & -0.3 & -0.2 & 0.0 & 0.0 \\
\hline Transactions under tranche policies (net) & -5.5 & -6.0 & -0.2 & -0.2 & -0.2 & -0.2 & -0.2 & -0.2 & -0.2 & -0.2 & -0.2 & -0.1 & 0.0 & 0.0 \\
\hline Poverty Reduction and Growth Facility (PRGF) & 5.0 & 5.0 & 12.8 & 23.2 & -0.3 & -0.3 & -1.8 & -4.2 & -7.3 & -11.2 & -11.1 & -9.5 & -7.1 & -3.9 \\
\hline Disbursements (2004 PRGF arrangement) & 7.9 & 7.9 & 15.7 & 23.5 & & $\ldots$ & & $\ldots$ & & & & & & \\
\hline Repayments & -2.8 & -2.8 & -2.9 & -0.2 & -0.3 & -0.3 & -1.8 & -4.2 & -7.3 & -11.2 & -11.1 & -9.5 & -7.1 & -3.9 \\
\hline Principal & -2.8 & -2.8 & -2.8 & 0.0 & 0.0 & 0.0 & -1.6 & -3.9 & -7.1 & -11.0 & -11.0 & -9.4 & -7.1 & -3.9 \\
\hline Of which : 2004 PRGF arrangement & 0.0 & 0.0 & 0.0 & 0.0 & 0.0 & 0.0 & 0.0 & -3.9 & -7.1 & -11.0 & -11.0 & -9.4 & -7.1 & -3.9 \\
\hline Interest & 0.0 & -0.1 & -0.1 & -0.2 & -0.3 & -0.3 & -0.3 & -0.3 & -0.2 & -0.2 & -0.1 & -0.1 & 0.0 & 0.0 \\
\hline Of which : 2004 PRGF arrangement & 0.0 & -0.1 & -0.1 & -0.2 & -0.2 & -0.2 & -0.2 & -0.2 & -0.2 & -0.2 & -0.1 & -0.1 & 0.0 & 0.0 \\
\hline \multirow[t]{2}{*}{ Total Fund credit outstanding, end of period } & 18.7 & 18.5 & 31.4 & 55.0 & 55.0 & 55.0 & 53.4 & 49.5 & 42.4 & 31.4 & 20.4 & 11.0 & 3.9 & 0.0 \\
\hline & \multicolumn{14}{|c|}{ (In percent of quota, unless otherwise indicated) } \\
\hline Total Fund credit outstanding, end of period & 22.1 & 21.9 & 37.2 & 65.0 & 65.0 & 65.0 & 63.1 & 58.5 & 50.1 & 37.1 & 24.1 & 13.0 & 4.6 & 0.0 \\
\hline PRGF disbursements & 9.3 & 9.3 & 18.6 & 27.7 & 0.0 & & & & & & & & & \\
\hline Repurchases/repayments & 9.5 & 9.9 & 3.3 & 0.0 & 0.0 & 0.0 & 1.9 & 4.6 & 8.4 & 13.0 & 13.0 & 11.1 & 8.4 & 4.6 \\
\hline Charges and interest & 0.3 & 0.6 & 0.4 & 0.5 & 0.6 & 0.6 & 0.6 & 0.5 & 0.5 & 0.4 & 0.4 & 0.2 & 0.0 & 0.0 \\
\hline \multirow{2}{*}{$\begin{array}{l}\text { Debt service (in percent of goods and } \\
\text { nonfactor services) }\end{array}$} & & & & & & & & & & & & & & \\
\hline & 0.3 & 0.3 & 0.1 & 0.0 & 0.0 & 0.0 & 0.1 & 0.1 & 0.3 & 0.4 & 0.4 & 0.3 & 0.2 & 0.1 \\
\hline
\end{tabular}

nonfactor

Sources: IMF, Finance Department, and staff projections. 
Table 12. Republic of Congo: Income and Social Indicators, 1970-2002

\begin{tabular}{|c|c|c|c|c|c|}
\hline & \multicolumn{3}{|c|}{ Latest Single Year } & \multicolumn{2}{|c|}{ Same Region/Income Group } \\
\hline & $\overline{1970-75}$ & $1980-85$ & -2002 & $\begin{array}{c}\text { Sub-Saharan } \\
\text { Africa }\end{array}$ & $\begin{array}{l}\text { Upper-middle- } \\
\text { income countries }\end{array}$ \\
\hline Total population, midyear (in millions) & 1.4 & 1.9 & 3.1 & 688.9 & $2,494.6$ \\
\hline Growth rate (annual average, in percent) & 2.7 & 2.8 & 2.9 & 2.4 & 1.9 \\
\hline Urban population (in percent of population) & 35.0 & 49.3 & 66.6 & 33.1 & 30.6 \\
\hline Total fertility rate (births per woman) & 6.3 & 6.3 & 6.3 & 5.1 & 3.5 \\
\hline GNI per capita (in U.S. dollars) & 530.0 & $1,060.0$ & 610.0 & 450.0 & 430.0 \\
\hline Consumer price index $(1995=100)$ & $\ldots$ & 60.6 & 136.0 & $\ldots$ & $\ldots$ \\
\hline Food price index $(1995=100)$ & $\ldots$ & 71.8 & 136.0 & $\ldots$ & ... \\
\hline Public expenditure & \multicolumn{5}{|c|}{ (In percent of GDP) } \\
\hline Health & $\ldots$ & $\ldots$ & 1.4 & 2.5 & 1.1 \\
\hline Education & 7.8 & 4.6 & 4.2 & 3.4 & 3.1 \\
\hline Gross school enrollment rates $1 /$ & \multicolumn{5}{|c|}{ (In percent of age group) } \\
\hline Primary & 135.8 & 147.4 & 96.9 & 78 & 107 \\
\hline Secondary & 47.6 & 75.4 & 41.9 & 25 & 64 \\
\hline Tertiary & 2.6 & 6.3 & 5.0 & 3 & 14 \\
\hline Immunization rate & \multicolumn{5}{|c|}{ (In percent of children under 12 months) } \\
\hline DPT & $\ldots$ & 54 & 41 & 54 & 65 \\
\hline Measles & $\ldots$ & 67 & 37 & 58 & 65 \\
\hline Life expectancy at birth & \multicolumn{5}{|c|}{ (In years) } \\
\hline Total & 48 & 51 & 52 & 46 & 59 \\
\hline Male & 45 & 48 & 50 & 45 & 58 \\
\hline Female & 51 & 54 & 54 & 47 & 60 \\
\hline \multicolumn{6}{|l|}{ Mortality rate } \\
\hline Infant (per thousand live births) & 100 & 88 & 81 & 103 & 79 \\
\hline Under 5 (per thousand live births) & 160 & 125 & 108 & 174 & 121 \\
\hline \multicolumn{6}{|l|}{ Adult (15-59) } \\
\hline Male (per 1,000 population) & 514 & 408 & 475 & 519 & 310 \\
\hline Female (per 1,000 population) & 395 & 298 & 406 & 461 & 259 \\
\hline
\end{tabular}

Source: World Bank, World Development Indicators, 2004.

1/ Gross enrollment rate: break in series between 1997 and 1998 is due to change from ISCED76 to ISCED97; ratios exceeding 100 indicate discrepancies between the estimates of school-age population and reported enrollment data. 
Mr. Rodrigo de Rato

Managing Director

International Monetary Fund

Washington, D.C. 20431

U.S.A.

Dear Mr. de Rato:

1. On behalf of the government of the Republic of Congo, I am pleased to submit herewith the Memorandum on Economic and Financial Policies (MEFP) for the first review of the three-year program supported by the arrangement from the International Monetary Fund (IMF) under the Poverty Reduction and Growth Facility (PRGF). This memorandum also presents indicative quantitative and structural benchmarks for the fourth quarter of 2005.

2. The government wishes to thank the IMF for its support, which has been instrumental in mobilizing the support of the international community in its development efforts. The government would also like to thank its other development partners that have already granted new financing to the Congo, as well as the Paris Club for its support of debt relief and rescheduling. In order to ease the debt burden weighing on the Congolese economy's growth potential, the government hopes that the Congo will qualify for debt relief under the enhanced HIPC Initiative with the shortest possible delay.

3. Overall, the implementation of the program supported by the PRGF yielded satisfactory results over the period beginning October 1, 2004 and ending March 30, 2005. Implementation of the structural measures improved transparency, good governance in the oil sector, and fiscal management. Nevertheless, the government requests a waiver for the failure to observe by end-March 2005 one quantitative criterion (payments of external arrears) and one structural performance criterion (completion of external audits of oil costs for 2003 for all production-sharing contracts). In addition, the government requests that the end-September 2005 target for arrears payments be revised following the rescheduling agreement with Paris Club creditors on December 16, 2004 and firm pledges from donors for the payment of one third of the arrears owed to the African Development Bank.

4. Since the approval by the IMF Executive Board of the program supported by the PRGF on December 6, 2004, new structural challenges to the Congolese economy have arisen, in particular in the banking, refined petroleum products, and electricity sectors. With a view to preserving macroeconomic and fiscal stability over the medium term and maintaining the objectives of the PRGF-supported program, the government has adopted a strategy, described in the attached memorandum, to remedy the structural weaknesses in these sectors. In this context, it intends to pursue vigorously the implementation of the measures emanating from the strategy described in the attached MEFP. 
5. Based on the positive results already achieved and the government's renewed commitment to continue implementing its economic and social program, the objectives of which are consistent with the interim Poverty Reductions Strategy Paper (I-PRSP), the authorities request the completion of the first review and support from the IMF in the form of a second tranche under the three-year arrangement supported by the PRGF.

6. The government believes that the policies set forth in the attached Memorandum on Economic and Financial Policies (MEFP) are adequate to achieve the objectives of the program, but it will take any other measures that may become appropriate for this purpose. The government of the Republic of Congo will consult with the Fund on the adoption of these measures, and in advance of revisions to the policies contained in the MEFP, in accordance with the Fund's policies on such consultation. The second review of the program supported by the PRGF arrangement with the IMF is expected to take place by January/February 2006.

7. The government is committed to disseminating its Memorandum on Economic and Financial Policies as well as the Technical Memorandum of Understanding and authorizes the IMF to publish its staff report, which will be examined by the Executive Board.

Sincerely yours,

$$
/ \mathrm{s} /
$$

Pacifique Issoïbeka

Minister of Economy, Finance, and Budget

Attachments: - Memorandum on Economic and Financial Policies

- Addendum to the Technical Memorandum of Understanding 


\title{
REPUBLIC OF CONGO
}

\author{
Memorandum on Economic and Financial Policies
}

July 15,2005

\section{INTRODUCTION}

1. The Republic of Congo, a post-conflict country, is continuing to make significant efforts to strengthen its medium-term macroeconomic and financial framework so as to achieve steady growth and trigger a sustainable reduction in poverty. The signing of peace agreements with the rebel groups in 1999 and 2003, and the establishment of democratic institutions in 2002 after the end of the political transition period, have contributed to the consolidation of peace.

2. This memorandum reviews program implementation in the context of the first review of the PRGF-supported program, as well as the macroeconomic and financial outlook for the remainder of 2005 and the medium term. Overall, program implementation was satisfactory over the period from October 1, 2004 to March 30, 2005. Nevertheless, since the approval by the IMF Executive Board of the program supported by the PRGF, the Congolese economy has had to face new structural challenges, in particular in the banking, refined petroleum products, and electricity sectors. The government has adopted a strategy, described in this memorandum, to remedy the structural weaknesses in these sectors while seeking to preserve fiscal stability over the medium term and to maintain the objectives of the PRGF-supported program, of which the fight against poverty continues to be the cornerstone.

\section{IMPlementation OF THE PRGF-SUPPORTEd PROGRAM}

3. The program supported by the PRGF has two main pillars, namely enhancing the transparency of public resource management, in particular in the oil sector, and improving fiscal discipline. Overall, the implementation of the PRGF-supported program produced satisfactory results over the period from October 1, 2004 to March 31, 2005.

4. The quantitative objectives for end-December 2004 (quantitative benchmarks) and end-March 2005 (quantitative criteria) were mostly achieved, notwithstanding the small slippage on budget execution at end-2004 (see Table 1).

- It bears noting that the amounts of external arrears payments for the fourth quarter of 2004 and the first quarter of 2005 were below the amounts projected in the program due to the more favorable rescheduling of arrears payments granted to the Congo by Paris Club creditors on December 16, 2004.

- At end-2004, the primary budget surplus was below the program target (adjusted to reflect the number of oil shipments marketed and the international oil price actually paid) by CFAF 55.2 billion. This situation arose in part from a CFAF 14 billion increase in 
expenditure resulting from the early execution of certain expenditures initially projected for $2005,{ }^{1}$ but especially to exogenous and technical factors. ${ }^{2}$ In addition, the payment of domestic arrears exceeded the program target by about CFAF 1 billion.

- At end-March 2005, the primary budget surplus exceeded the program target (adjusted to reflect the number of oil shipments marketed and the international oil price actually paid) by CFAF 32 billion. Primary expenditure was lower than the program target while nonoil revenue exceeded the target. All the other performance criteria and quantitative indicators for end-March 2005 were observed.

5. All of the structural performance criteria for end-December 2004 and endMarch 2005 were observed, with the exception of the criterion on the audits of oil costs for 2003 for all production-sharing contracts (see Table 2). Completion of these audits has taken longer than expected owing to the complexity of the work to be carried out. However, these audits are at an advanced stage and their completion constitutes a prior action for conclusion of the first review of the PRGF-supported program (see Table 3). Moreover, most other structural benchmarks were observed (see Table 2). Although the structural benchmark relating to the adoption of a restructuring plan by the COFIPA bank's board of directors was observed, the plan needs to be strengthened by taking into account additional cost-cutting measures.

\section{Fight Against Poverty}

6. Work is in progress on preparing the final PRSP. In this context, the following steps will be implemented in 2005: (i) strengthening the National Committee on Combating Poverty; (ii) strengthening the representation of civil society organizations on the Permanent Technical Secretariat; (iii) organizing a government seminar on the formulation and implementation of the poverty reduction strategy, and proposing measures to address the concerns of the private sector and civil society; (iv) developing an action plan for the effective participation of civil society organizations, the private sector, and Parliament in the process of preparing and drafting the final PRSP; (v) conducting surveys on household

\footnotetext{
${ }^{1}$ The outlays were related to the Impfondo project, the implementation of which was moved forward to late 2004 instead of the first half of 2005 owing to the low flow on the Congo River.

${ }^{2}$ The shortfall in oil revenues (estimated by applying the adjustment provided for in the program) of CFAF 46.6 billion may be explained by three factors: (i) the revenue from two shipments of oil marketed in November 2004 was received in the first quarter of 2005 (CFAF 34.2 billion); (ii) the discount applied to Congolese crude relative to the reference price on the world market, like that of the other countries in the region, rose sharply toward the end of 2004 (CFAF 10.1 billion); and (iii) a technical margin of error relating to the adjustment of shipment volumes (CFAF 2.3 billion).
} 
expenditures, and on demography and health; and (vi) preparing a detailed timetable for implementing a functional classification of government expenditures.

7. Pending a comprehensive revision of the functional classification of government expenditure, poverty reduction outlays will be monitored within the existing framework which covers the priority sectors as defined in the PRSP and the amounts, structure, and evolution of pro-poor spending. A table tracking poverty-reducing spending in 2004 will be prepared by end-June 2005. In addition, by end-June 2005 the government will prepare a table with data tracking the expenditure circuit (commitment, payment order, and cash payment) for the first quarter of 2005; this effort will be verified by the InspectorateGeneral of Finance.

8. Some weaknesses were encountered in the implementation of the I-PRSP in 2004. The share of pro-poor spending in total primary expenditures was 21 percent against an objective of 23 percent. Underspending was greatest in basic health and education. The government is determined to refocus its attention on poverty reduction. It will raise the share of pro-poor spending in total primary spending to a targeted 30 percent in 2005. Spending on basic health (including the fight against HIV/AIDS) is expected to double, and that related to basic education to increase by a fourth. As of the first quarter of 2005, the execution rate of pro-poor spending stood at 38 percent of the annual envelope. Given the focus on lowering poverty, the government will monitor pro-poor spending on a quarterly basis.

\section{EnhanCED MACROECONOMIC AND Structural FramewORK}

9. Because world market prices for oil rose more than projected in the program, oil revenue is expected to be higher in 2005-07 than indicated in the reference scenario of the program, despite the fact that oil production will be lower than projected during this period. In addition, after the approval of the PRGF-supported program by the IMF Executive Board, new structural challenges were brought to light in the refined petroleum products, banking, and electricity sectors. In order to preserve fiscal stability over the medium term and maintain the objectives of the PRGF-supported program, including the reorientation of public expenditures toward poverty-reducing spending, the government intends to tackle these new problems.

10. The macroeconomic framework has been updated to take account of: (i) a projected increase in oil revenues; (ii) an increase in external debt payments following the agreement reached with the Paris Club on December 16, 2004; and (iii) an increase in pro-poor spending. After all these factors are taken into account, the revised macroeconomic framework projects: (i) an average annual growth rate of about 5.2 percent over the period 2005-07; (ii) an inflation rate of about 2 percent a year, assuming a sound fiscal policy and the continuation of a prudent monetary policy by the BEAC; (iii) a primary budget surplus of 17.7 percent of GDP in 2005 and 10.3 percent of GDP on average in 2006-07; and (iv) an external current account surplus averaging about 3.3 percent of GDP. 
11. In keeping with the program, additional oil revenue will be deposited in the banking system and their use thereof will be discussed with Fund staff in connection with the reviews of program execution, in accordance with the modalities for program monitoring laid out in the Technical Memorandum of Understanding (TMU) (Country Report No. 05/7, Appendix I, Attachment III, para. 24). As described in that memorandum, the program incorporates an adjustment factor to take account of any deviations from programmed amounts of oil revenue (owing to quantity and price changes).

\section{A. Fiscal Policy}

12. The major fiscal policy objectives under the PRGF-supported program are to: (i) enhance the mobilization of oil and non-oil revenues; (ii) avoid procyclical spending and fight inflationary pressures; (iii) increase pro-poor spending; (iv) limit budgetary transfers and streamline government policy on subsidies; (v) settle domestic payments arrears transparently and equitably; and (vi) continue to normalize relations with external creditors.

\section{The government undertakes to continue its efforts to enhance oil and non-oil} revenue mobilization:

- Oil revenues will be maximized thanks to quarterly certifications, audits of oil costs, and improving the financial performance of the SNPC and CORAF. In view of the projected oil price increases in the international market, the revised forecast for oil revenue in 2005 amounts to CFAF 793.7 billion (as compared to CFAF 632.4 billion in the original program) and are based on the assumption of a volume of production of 94.7 million barrels, an international price of US $\$ 45.20$ per barrel of Brent crude oil, and an exchange rate of CFAF $499=\mathrm{US} \$ 1$.

- Non-oil revenues will be increased as a result of the strengthening of measures to combat fraud and tax evasion, computerization of the revenue departments and strengthening of the tax and customs administrations, control and limitation of discretionary tax exemptions, and broadening of the tax base. For 2005, it is projected that non-oil revenues will amount to CFAF 219.3 billion, or 18.7 percent of non-oil GDP.

14. Expenditure policy will focus on poverty reduction. The government undertakes to increase the share of resources allocated to the priority social sectors identified in the I-PRSP, namely: (i) basic health care and action to combat HIV/AIDS; (ii) basic education; (iii) basic infrastructure; (iv) water, energy, and urban sanitation; (v) disarmament and reintegration of former combatants; and (vi) agriculture. In view of the increase in oil revenue, it is projected that these expenditures will be increased by CFAF 25 billion (or 0.9 percent of GDP) in 2005. Expenditure management priorities will include the oversight of the services rendered, especially as regards investment expenditure, limiting recourse to exceptional expenditure procedures, and improved monitoring of transfers.

15. As regards the problem sectors (banking, fuel, and energy), only documented and duly validated losses will be eligible for being covered by the budget. In addition, far- 
reaching reforms will be implemented to address the structural weaknesses in these sectors so as to limit, if not eliminate, their negative impact on future budgets (see Section V).

16. Budgetary costs in the banking sector are estimated at CFAF 8.4 billion. In response to the deterioration in COFIPA's financial performance and the major shareholders' failure to contribute to COFIPA's recapitalization, the government has been obliged to take over the bank temporarily in order to prepare its orderly reprivatization and to protect depositors. The cost of recapitalizing this bank has been estimated by COBAC at CFAF 2.4 billion. The government stands ready to sell this bank to the private sector once the proper conditions have been met. In addition, in accordance with the agreement signed with the investors taking over the former public sector bank CAIC, the government will pay La Congolaise de Banque (LCB) CFAF 6 billion to cover the amount of nonperforming assets transferred at the time of the changeover in ownership, as validated by COBAC.

17. The financial losses of the refined petroleum products sector are estimated at CFAF 37.8 billion at end-2004 (1.9 percent of GDP), of which CFAF 28.3 billion are the losses of CORAF and CFAF 9.5 billion are losses emanating from downstream activities (relating to the storage, transport, and distribution of refined products and the high cost of supplying Brazzaville via Kinshasa). Following these losses, in 2004 CORAF incurred payments arrears estimated at CFAF 22 billion vis-à-vis its suppliers of crude oil. A plan for settling these arrears is under discussion between the SNPC and CORAF on the one hand, and the oil suppliers on the other. In view of the higher-than-programmed oil prices, the subsidy initially projected for the subsector as a whole will be revised upward by an average of CFAF 2.3 billion a year during 2005 to 2007 to take account of the rise in world market prices for oil. The government undertakes to take steps to minimize the subsector's costs to the government budget (see Subsection V B).

18. The National Electricity Company (SNE) regularly incurs sizable payments arrears vis-à-vis its sister firm from the Democratic Republic of Congo, the SNEL, for purchases of electricity from that company. This is explained by the financial difficulties of SNE, principally the result of the destruction of its plants during the armed conflicts of earlier years, fraud and theft in consumption of electricity, a flat-rate invoicing of consumption in the absence of meters, and non-payment of bills by a large number of customers. As of December 31, 2004, the debt owed to SNEL amounted to CFAF 36.7 billion, all of it arrears. The government intends to undertake a reconciliation of these arrears before finding a solution to this problem. Based on the reconciled figures, negotiations will be initiated between the Republic of Congo and the Democratic Republic of Congo on how to deal with these arrears. In the meantime, the two parties have agreed that the Republic of Congo should settle its current bills on a regular basis. Consequently, the central government subsidy to SNE to help it honor its current payments is estimated at CFAF 350 million a month in 2005; this subsidy should drop to CFAF 175 million a month beginning in 2006 on the assumption that the reforms contemplated in this sector will begin to bear fruit (see Subsection V C). 


\section{B. Monetary and Financial Sector}

19. Monetary policy will continue to be conducted regionally by the Bank of Central African States (BEAC). The objectives of this policy are to ensure low inflation and maintain the zone's foreign exchange reserves at a comfortable level. The government of Congo will contribute to achieving these objectives by implementing a fiscal policy aimed at increasing public savings so as to improve the government's net position vis-à-vis the banking system and permit a noninflationary increase in credit to the economy. Broad money should grow in line with nominal non-oil GDP during the program period. According to projections, net credit to the government (excluding IMF resources) is expected to decrease by CFAF 36 billion in 2005. Also projected are credit growth to the economy in line with the change in nominal non-oil GDP, and an improvement in the net foreign assets of the central bank.

20. The government is resolved to take the actions needed to address the fragility of the banking sector.

- The launching, by an audit firm of international reputation, of the general audit of the status of COFIPA's loan portfolio as of March 31, 2005 is expected before endJune 2005, and is expected to be completed by end-October 2005 .

- A revised restructuring plan for the COFIPA bank will be adopted by end-December 2005. This plan will include concrete measures to reduce the bank's operating costs ${ }^{3}$ and to increase its resources, including by the sale of some assets. The revised plan will incorporate the findings of the loan portfolio audit referred to above, and will clarify the status of the owners of this bank through an independent legal judgment.

- The government will provide IMF staff with quarterly reports on the financial position of COFIPA, prepared by COBAC after a site visit. These reports will take stock of the solvency, profitability, and liquidity of the bank, as well as the implementation of the recommendations set forth in the October 18, 2004 report entitled "COFIPA Investment Bank Congo: Evaluation and Restructuring." The first report on the situation at endJune 2005 will be available by end-September 2005 .

- The government undertakes to reprivatize the COFIPA bank within a realistic period of time by means of an open competitive bidding conducted with the greatest possible transparency.

21. The government is determined to take the steps necessary to minimize the moral hazard problem, whereby banks make relatively little effort to recover claims, hoping that the government will always stand ready to serve as the savior of last resort in the event of

\footnotetext{
${ }^{3}$ In particular the closure of some unprofitable branches and the reduction of operating costs, including personnel costs.
} 
difficulties. The government will ensure that a strategy is introduced to strengthen the recovery of bank claims. To this end, by end-October 2005, the government will prepare, with assistance from the $\mathrm{BEAC}$ and $\mathrm{COBAC}$, an action plan for strengthening the recovery of bank claims. In addition to the strengthening of credit recovery, measures will be put in place to combat default or late payment by major debtors. These measures will include:

(i) more active use of the central credit register to prevent a customer who is in default visà-vis one bank from easily obtaining financing from other banks; and (ii) preparation, based on information from the La Centrale des Risques, of a list of principal delinquent debtors of the Congolese banking system, and circulation of this list in banking establishments and in the Public Treasury (prior action for conclusion of the first review of the PRGF-supported program).

\section{External Debt}

22. The government is continuing its efforts to normalize relations with external creditors. Indeed, all external liabilities have been honored on time since the introduction of the PRGF-supported program. Furthermore:

- As regards Paris Club creditors, following the debt relief agreement signed on December 16, 2004, the government has already approached the members of that institution with a view to negotiating and signing bilateral agreements. Agreements have already been signed with Germany, Canada, Spain, and Italy; the government hopes it will be able to sign agreements with all the other creditors before the deadline.

- As regards relations with bilateral creditors which are not Paris Club members, discussions have been held with the Kuwait Fund and Saudi Fund. Responses from the other bilateral creditors are expected.

- As regards the London Club creditors, the government plans to pursue in the period ahead discussions initiated in 2004 with the Steering Committee and to reconcile the debt amounts. The government plans to request financial assistance from the World Bank's IDA Debt Reduction Facility for repurchasing the debt owed to London Club creditors.

- In keeping with the principles of the HIPC Initiative, the government intends to settle its arrears vis-à-vis private creditors, including those in litigation. Despite the rulings already handed down against the Congo and the legal actions in progress in the courts, the authorities are continuing their contacts with the funds holding a substantial share of the Congo's commercial debt with a view to finding amicable out-of-court settlements.

23. In preparation for the Congo's access to the enhanced HIPC Initiative, work is continuing, in close collaboration with IMF and World Bank staff, to examine and analyze the various categories of the government's and public enterprises' external debts, including the financial liabilities of the SNPC. In particular, key questions have yet to be answered as regards the SNPC's advance accounts, as regards the amounts, their nature, and the residency status of the creditors. 


\section{Structural Reforms AND Governance}

\section{A. Oil Sector Upstream}

24. The efforts to improve the mobilization of oil revenue and enhance transparency in the oil sector will continue. The key actions for the remainder of 2005 are as follows:

- Completion, by an audit firm of international reputation, of a reconciliation report on the amount of oil revenues deposited in government bank accounts, as reported in the quarterly certification reports, and the total oil revenues reported in the government financial operations tables (TOFEs) for 2003 and 2004 (prior action for the conclusion of the first review of the PRGF-supported program).

- Completion, by audit firms of international reputation, of the audits of oil costs for 2003, for all production-sharing contracts as defined in these contracts, and submission of the reports to the government (prior action for the conclusion of the first review of the PRGF-supported program).

- Certification of the government's oil revenue by an audit firm of international reputation will continue on a quarterly basis.

- Preparation by the SNPC of a statement of sources and uses of funds for the consolidated activities of the SNPC group for 2004, and quarterly tables for 2005 (end-June 2005).

- Adoption by the government of a definitive strategy to refocus the activities of SNPC on its core activities in the oil sector, along with the related implementation timetable (endSeptember 2005).

- Completion of the audit of the SNPC's accounts for 2004 by an audit firm of international reputation (end-March 2006).

25. The government will continue to increase the amount of information made available to the public on Internet sites (www.mefb-cg.org), including the publication of audit reports (among which the external audit reports on the SNPC and CORAF), information on the operations of the oil sector, and legal and regulatory texts governing relations between the government and the SNPC. The government further reiterates its commitment to publishing on the Internet all information relating to hydrocarbons transactions, as defined in the Technical Memorandum of Understanding for the PRGF-supported program.

\section{B. Refined Petroleum Products Sector}

26. The losses of the refined products sector continue to mount and to pose a burden on the government budget. These losses arise partly from the increase in the world market price of crude oil and partly from the fixing by administrative decree of the ex-refinery and pump prices for refined petroleum products, inefficiencies in the refining and distribution of refined petroleum products, as well as the high cost of supplying Brazzaville through 
imports from Kinshasa. To reduce the potential budgetary costs of this sector, while at the same time minimizing the impact on the poor, the following measures are envisaged:

- Validation of the losses recorded by the refined petroleum products sector (including CORAF) in 2004. This work will be carried out in two stages. First, the government will sign a contract with an audit firm of international reputation to conduct an audit of CORAF's accounts for 2003 and 2004, using the same terms of reference as per the 2002 audit (prior action for conclusion of the first review of the PRGF-supported program). Completion of this audit is expected by end-December 2005. Second, by endSeptember 2005 the government will sign a contract with an audit firm of international reputation to validate the losses of the refined petroleum products sector other than CORAF.

- Adoption by the government of a decree implementing a new price structure for refined petroleum products which incorporates: (i) an increase of CFAF 115/liter in the price of jet fuel sold to international airlines, (ii) an increase of CFAF 40/liter in the price of gasoil sold to international shipping companies, and (iii) a reduction of 25 percent in the margins (transport, storage, distribution, and marketing) in the price structure (prior action for conclusion of the first review of the PRGF-supported program).

- Preparation, with World Bank assistance, of an economic and strategic study of CORAF aimed at adopting an action plan for restructuring the enterprise. This study will be launched by August 2005 and its completion is expected by December 2005. Pending the results of the study, the CORAF Board of Directors will adopt a plan for cutting operating costs, including the costs of personnel, technical assistance, and marketing.

- Adoption by the government of an action plan (including a timetable) for the implementation of an automatic price adjustment mechanism for refined petroleum products (end-September 2005). An analysis of the social impact of this reform will be conducted in order to identify associated measures to be taken to protect poor and vulnerable population groups.

\section{Energy Sector}

27. Reform of the electricity sector is continuing, with assistance from the World Bank in the context of the project to rehabilitate the energy and water infrastructures. The government is keen to reduce the losses of SNE and the resulting burden on the government budget.

28. The primary objective for the immediate future is to improve the financial position of SNE, and particularly to increase the revenues collected at Brazzaville and Pointe-Noire, so as to cover SNE's expenses and thereby to reduce the burden on the government budget. The following actions are contemplated: 
- To conduct oversight of the SNE's accounts, the government will sign a contract with an accounting firm of international reputation to draw up the 2004 financial accounts of the company in accordance with the standards of OHADA. This work is scheduled to be completed by end-November 2005 .

- In order to increase SNE revenues, it is planned to install meters in Brazzaville to measure and invoice actual consumption rather than use flat-rate invoicing. ${ }^{4}$ Flat-rate invoicing encourages overconsumption and piracy, and gives rise to considerable revenue shortfalls for the SNE. The SNE has already installed 4,300 meters and intends to install 13,000 more by September 2005 and 5,000 additional ones by end-December 2005. This should make it possible to increase SNE's collection ratio from 78 percent at end-2004 to 116 percent by end-December $2005^{5}$

29. In the years ahead, the public investment program financed by domestic resources will provide for: (i) capacity building in the energy sector with the rehabilitation of the Mokoukoulou dam; (ii) construction of the thermal power plant in Brazzaville (planned for 2006) and the Imboulou dam (2009); and (iii) strengthening the distribution, transport, and interconnection grids (2006). In the medium term, the government has committed to a program for rehabilitating SNE equipment in collaboration with the World Bank so as to improve SNE performance and address its high debt level.

\section{Other Good Governance Measures}

30. The government is resolved to enhance the transparency of natural resource management. In June 2004, the government joined the Extractive Industries Transparency Initiative (EITI). The government had the opportunity to reaffirm this commitment at a round table organized by a NGO in Pointe-Noire in February 2005 and attended by nongovernmental organizations and the oil companies. Because of the progress made in improving transparency in the management of oil revenues, the Republic of Congo received a special mention at the EITI conference held in London in March 2005. Looking ahead, the government intends to present, for discussion, an action plan for achieving the EITI objectives at a meeting with industry and civil society representatives in mid-2005. In addition, the government is currently taking the steps necessary to bring the Republic of Congo back into the Kimberley Process for the certification of diamonds, from which the country was excluded in June 2004. A geological and mining research firm has been

\footnotetext{
${ }^{4}$ The flat-rate system was introduced in Brazzaville (and not in Pointe-Noire) as a palliative measure following the destruction of meters during the civil wars of the 1990s.

${ }^{5}$ The collection rate is defined as cash collected (minus value added tax) by the national electricity company (SNE) from its customers in Brazzaville on average for the past three months divided by the invoice for imports from the national electricity company (SNEL) in the Democratic Republic of Congo, also on average over the past three months.
} 
contacted with a view to conducting a study of raw diamond production capacity in the Congo.

\section{E. Statistical Data}

31. The government is committed to improving the quality of the statistics needed for properly monitoring the implementation of the PRGF-supported program and the poverty reduction strategy. A Multi-Year Plan for the Development of Statistics (PPDS) has already been prepared; it is expected to be adopted by end-2005. In addition, six consultants have been hired to convert the national accounts in accordance with the United Nations' 1993 methodology (SNA 93). This measure is now expected to be completed by end 2006.

\section{SECURITY SituATION}

32. The government is cognizant of the fact that consolidation of the peace process which began in 2000, as well as improving the security situation, are key factors in the country's development. In this context, the recently created "Committee to Monitor the Commitments Made in the Cross Agreements of March 16 and 17, 2003" constitutes an important step in efforts to promote peace. The government is committed to accelerating the demilitarization, disarmament, and reintegration program (DDR Program) with the involvement of all stakeholders, including the United Nations.

\section{Program Monitoring}

33. To strengthen the macroeconomic framework of the program in order to guarantee sustainable growth and a lasting reduction of poverty, the government has committed to adopting a strategy involving a number of prior actions to be taken before conclusion of the first review of the PRGF-supported program (see Table 3).

34. Program execution will be monitored by means of the performance criteria and quantitative and structural benchmarks specified in Tables 1 and 2 and described in the TMU (Country Report No. 05/7, Appendix I, Attachment III). To enable the government to properly implement its poverty reduction program, indicative quantitative and structural benchmarks have been defined for the fourth quarter of 2005. Definitions and other details on these benchmarks may be found in the TMU, and an addendum to that TMU (attached hereto). 
Table 1. Republic of Congo: Quantitative Criteria and Indicators for October 2004- December 2005 (In billions of CFA francs, unless otherewise indicated; cumulative from January)

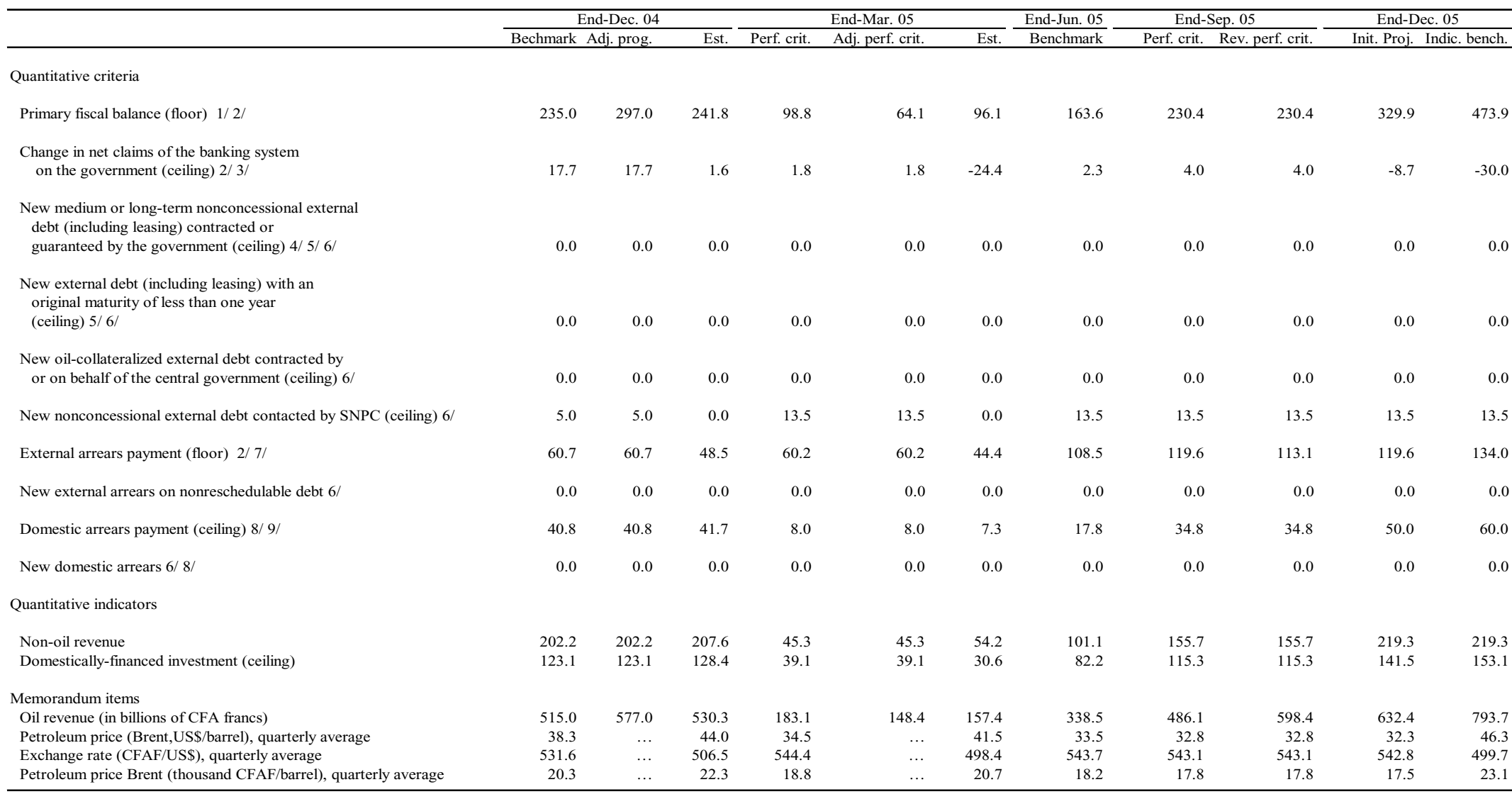

1/ See paragraph 6 of the technical memorandum of understanding (TMU) (Country Report 05/07; Appendix I, Attachment III) for the definition. 2/ See paras. 23-25 of the TMU on the adjustors.

3/ Excluding IMF credit.

4/ Excluding rescheduling arrangements and disbursements from the IMF.

5/ See para. 13.b of the TMU for the definition of cors

6/ Continuous performance criterion; see para. 17 of the TMU for the definition of nonreschedulable debt.

Excluding cancellation of arrears to the European Union, cancellation of part of arrears by the African Development Bank (AfDB), and clearance of arrears of

Congolese Embassies abroad. The revised performance criterion for end-September 2005 and indicative benchmark for end-December 2005 exclude all

arrears repayments to the AfDB, given that donors made firm pledges to pay the remaining one third of these arrears.

9/ $\mathrm{Sec}$ a 
Table 2. Republic of Congo-Structural Performance Criteria and Benchmarks for the First Program Year ${ }^{1}$

\section{Structural performance criteria}

Completion, by an audit firm of international reputation and in

Done accordance with international standards on auditing, of the 2002 external financial audit of CORAF, and submission of the report to the government.

Completion, by audit firms of international reputation and in accordance with international standards, of audits of oil costs for 2003 , for all production-sharing contracts as defined in these contracts, and submission of the reports to the government.

Preparation by the government and submission to the IMF of a table March 31, 2005

Done with data tracking the expenditure circuit (commitment, payment order, and cash payment) in 2004.

Preparation by the government and submission to the IMF of a table tracking poverty-reducing spending in 2004.

Adoption by the government of an action plan (including a timetable) for the introduction of an automatic price adjustment mechanism for refined petroleum products.

Certification of forestry revenues in 2004 by an audit firm of international reputation, and submission of the report to the government.

\section{Structural benchmarks}

Adoption, by the board of directors of a bank in difficulty, of a restructuring plan approved by the Central African Banking Commission (COBAC) and the government. ${ }^{2}$

Implementation by the Hydrocarbons Unit of the Ministry responsible March 31, 2005

Done for Finance of the nine recommendations made by the international audit firm in the context of the certification of oil revenues in 2003, and increase in the staffing of this unit from three to six qualified officials.

Completion, by an audit firm of international reputation and in March 31, 2005

Done accordance with international standards on auditing, of the external audit of the SNPC for 2003, and submission of the report to the government. 
Table 2. Republic of Congo-Structural Performance Criteria and Benchmarks for the First Program Year ${ }^{1}$ (concluded)

Preparation by the SNPC of a statement of sources and uses of funds for June 30, 2005 the consolidated activities of the SNPC group for 2004, and quarterly tables for 2005 .

Adoption by the government of a definitive strategy to refocus the September 30, 2005 activities of the SNPC on its core activities in the oil sector along with the related implementation timetable.

Adoption by the government of a comprehensive plan for the settlement of domestic arrears; posting of the related policy on an Internet site.

Quarterly publication on the Internet of the recipients of domestic debt payments.

Quarterly certification of oil revenue by an audit firm of international reputation using the same terms of reference as for the 2003 certification; certification reports to be published on Internet sites.

Publication on Internet sites of a detailed statement of all hydrocarbons transactions (oil and gas).

Centralization of all public revenues and execution of all public payments by the Treasury.

September 30, 2005

With one-month lag

Done

With one-month lag

Done $^{3}$

With one-month lag

Not done

Continuous

Done $^{3}$

${ }^{1}$ The measures are described in the technical memorandum of understanding (see IMF Country Report no. 05/7; January 2005).

${ }^{2}$ Failing this, COBAC and the government will automatically take interim measures and impose a restructuring plan by December 31, 2004.

${ }^{3}$ A part of oil revenue due by Operator 6 was not received by the Treasury. 
Table 3. Republic of Congo: Prior Actions for the First Review Under the PRGF Arrangement

Completion, by audit firms of international reputation and in accordance with international standards, of audits of oil costs for 2003, for all production-sharing contracts as defined in these contracts, and submission of the reports to the government.

Completion, by an audit firm of international reputation, of a reconciliation report on the amount of oil revenues deposited in government bank accounts, as reported in the quarterly certification reports, and the total oil revenues reported in the government financial operations tables (TOFEs) for 2003 and 2004; publication of the report on the Internet site of the Ministry of Economy and Finance (www.mefb-cg.org).

Establishment by the government, based on information from the La Centrale des Risques, of a list of and the principal delinquent debtors of the Congolese banking system, and circulation of this list to banking establishments and Public Treasury.

Signing by the government of a contract with an audit firm of international reputation to conduct annual external audits of CORAF for 2003 and 2004.

Adoption by the government of a decree implementing a new price structure for refined petroleum products which incorporates: (i) an increase of CFAF 115/liter in the price of jet fuel sold to international airlines, (ii) an increase of CFAF 40/liter in the price of gasoil sold to international shipping companies, and (iii) a reduction of 25 percent in the margins (transport, storage, distribution, and marketing) in the price structure. 
Table 4. Republic of Congo: Indicative Benchmarks for Fourth Quarter 2005 Under the PRGF Arrangement

Action

Date

Completion, by an audit firm of international reputation, of a general audit of the statement of the COFIPA loan portfolio as of March 31, 2005.

Preparation by the government, with the help of the Central African

November 30, 2005 Banking Commission (COBAC), of an action plan for strengthening the recovery of the banking system's nonperforming loans.

Completion, by an audit firm of international reputation, of the December 31, 2005 establishment of the 2004 financial accounts of the National Electricity Company (SNE) in accordance with the standards of the regional business law harmonization agency (OHADA).

Completion, by an audit firm of international reputation and in December 31, 2005 accordance with international standards on auditing, of the financial audit of the national refinery company (CORAF) for 2003 and 2004 , and submission of the report to the government.

Completion of the final report on the diagnostic assessment of the losses recorded by the refined petroleum products sector in 2004.

Preparation of a quarterly report by the government, in cooperation with the Central African Banking Commission (COBAC), on the financial situation of COFIPA following a site visit. ${ }^{1}$

Quarterly publication on the Internet of the recipients of domestic debt payments.

Quarterly certification of oil revenue by an audit firm of international reputation, using the same terms of reference as for the 2003 certification; certification reports to be published on Internet sites.

Publication on Internet sites of an itemized statement of all transactions relating to hydrocarbons (oil and gas).

Centralization of all public revenue and execution of all public payments by the Treasury.

October 31, 2005

December 31, 2005

With a one quarter lag

With a one quarter lag

With a one quarter lag

With a one quarter lag

Ongoing

${ }^{1}$ The reports will assess the solvency, profitability, and liquidity of this bank, as well as the implementation of the recommendations set forth in the report of October 18, 2004 entitled "COFIPA Investment Bank Congo: Evaluation and Restructuring." 
Table 5. Republic of Congo: Government Budgetary Operations, 2004-05 (In billions of CFA francs; cumulative from January)

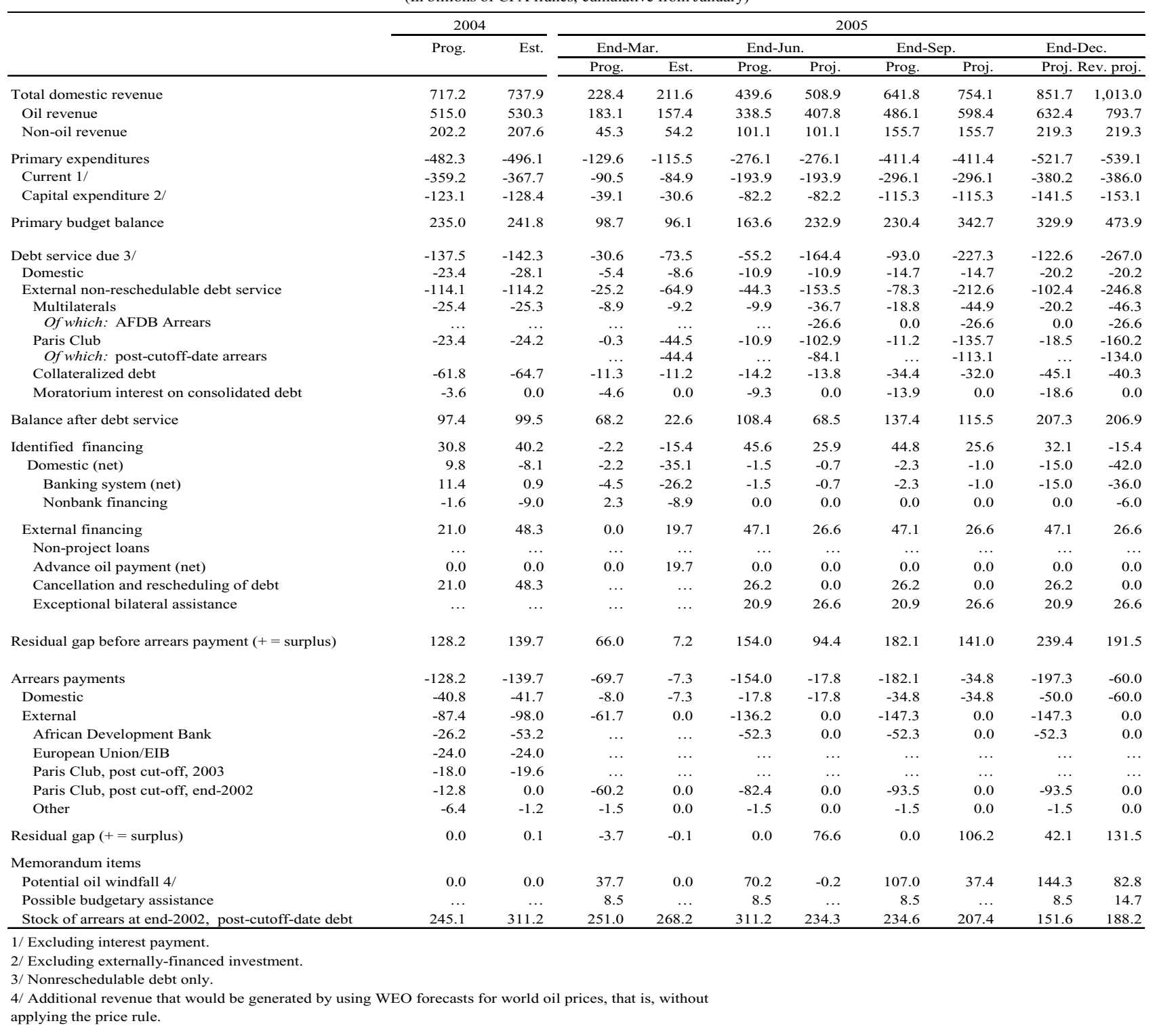




\section{REPUBLIQUE OF CONGO}

\section{Addendum to the Technical Memorandum of Understanding}

1. This addendum supplements the Technical Memorandum of Understanding of November 17, 2004 (hereafter the TMU), which sets out the modalities for monitoring the program of the government of the Republic of Congo covering the period from October 1, 2004 through September 30, 2005 (see IMF Country Report No. 05/7, Appendix I, Attachment III). Indicative structural and quantitative benchmarks have also been defined for the last quarter of 2005. The definitions and the frequency and deadlines for reporting data to the staff of the International Monetary Fund (IMF) for program monitoring purposes remain unchanged.

2. The updating of the quarterly projections ${ }^{1}$ of oil revenues is based on the following crude oil shipment schedule:

Table 1. Congo: Government Oil Shipments, 2004-05

(Number of commercial shipments)

\begin{tabular}{|c|c|c|c|c|c|c|c|c|c|c|}
\hline \multirow[b]{3}{*}{ Product/Blend } & \multirow{2}{*}{\multicolumn{2}{|c|}{$\frac{2004}{\mathrm{Q} 4}$}} & \multicolumn{8}{|c|}{2005} \\
\hline & & & \multicolumn{2}{|c|}{ Q1 } & \multicolumn{2}{|c|}{$\mathrm{Q} 2$} & \multicolumn{2}{|c|}{ Q3 } & \multicolumn{2}{|c|}{ Q4 } \\
\hline & Prog. & $\overline{\text { Actual }}$ & Prog. & $\overline{\text { Actual }}$ & Prog. ${ }^{1}$ & $\begin{array}{l}\text { Fore- } \\
\text { cast }\end{array}$ & Prog. ${ }^{1}$ & $\begin{array}{l}\text { Fore- } \\
\text { cast }\end{array}$ & $\begin{array}{l}\text { Original } \\
\text { forecast }\end{array}$ & $\begin{array}{l}\text { Revised } \\
\text { Forecast }^{1}\end{array}$ \\
\hline Djéno & 4 & 7 & 7 & 4 & 5 & 7 & 6 & 5 & 6 & 7 \\
\hline N'Kossa & 3 & 3 & 2 & 2 & 3 & 3 & 2 & 4 & 2 & 3 \\
\hline Yombo & 0 & 0 & 1 & 1 & 1 & 0 & 0 & 1 & 1 & 0 \\
\hline Butane & 3 & 2 & 3 & 4 & 2 & 3 & 2 & 2 & 1 & 3 \\
\hline Propane & 0 & 0.4 & 1 & 0.4 & 0 & 0.6 & 1 & 1 & 0 & 1 \\
\hline TOTAL & 10 & 12.4 & 14 & 11.4 & 11 & 13.6 & 11 & 13 & 10 & 14 \\
\hline
\end{tabular}

1/ To be used for program assessment.

In support of this revised schedule and in the event of any actual deviations from this schedule, the government will provide explanatory tables linking production by type of product to taxes, storage, and pick-ups.

\footnotetext{
${ }^{1}$ To take account of the usual one-month lag between the date of pick-up and the date of receipt of the proceeds, the quarters are defined as follows: 2005 Q1, Dec. 2004-Feb. 2005; 2005 Q2, March-May 2005; 2005 Q3, June-August; 2005 Q4, Sept.-Nov. 2005. See also the TMU, para. 8.
} 
3. If the primary surplus exceeds the program quantitative indicator (TMU, para. 2a) and/or if additional nonearmarked budgetary assistance ${ }^{2}$ over and above the programmed amount becomes available, the government will use these extra resources as set out in the TMU (para. 24) with one change. Following the agreement between the Congo and Paris Club creditors of December 16, 2004, the clause of using one-third of the extra resources to further reduce external payment arrears on government debt not eligible for rescheduling is redundant.

4. In cooperation with the professional association of credit institutions of the Congo, the government will draw up a list (extracted from the central credit register) of the most delinquent debtors of the banking system of the Republic of Congo. The most delinquent debtors will be defined as those who have accumulated arrears exceeding CFAF 10 million toward one or more banks in the marketplace for a period exceeding three consecutive months. The list will be updated quarterly.

5. A general audit will be conducted of the statement as of March 31, 2005 of the COFIPA loan portfolio by an audit firm of international reputation in accordance with bank audit standards and principles in effect in the Central African Economic and Monetary Community. The auditor will be tasked with:

(i) preparing a valuation of the bank's loan portfolio;

(ii) verifying the accuracy of the recording of the loans on the books of the bank;

(iii) examining the validity of the collateral provided; and

(iv) identifying and examining the validity of all off-balance sheet commitments of the bank.

${ }^{2}$ Budgetary support is defined as the amount of nonproject grants and loans (excluding IMF resources). 
Republic of Congo: Relations with the Fund

(As of May 31, 2005)

I. Membership Status: Joined: 07/10/1963; Article VIII

II. General Resources Account:

$\begin{array}{lrr} & \text { SDR Million } & \text { \%Quota } \\ \text { Quota } & 84.60 & 100.00 \\ \text { Fund holdings of currency } & 86.72 & 102.51 \\ \text { Reserve tranche position } & 0.54 & 0.63\end{array}$

III. SDR Department:

$\underline{\text { SDR Million }}$

9.72

0.61

Holdings
\%Allocation

100.0

6.25

\%Quota

14.22

3.13

ESAF arrangements

$\underline{\text { SDR Million }}$

12.03

2.64

V. Latest Financial Arrangements:

\begin{tabular}{|c|c|c|c|c|}
\hline Type & $\begin{array}{c}\text { Approval } \\
\text { Date }\end{array}$ & $\begin{array}{c}\text { Expiration } \\
\text { Date }\end{array}$ & $\begin{array}{c}\text { Amount } \\
\text { Approved } \\
\text { (SDR Million) }\end{array}$ & $\begin{array}{c}\text { Amount } \\
\text { Drawn } \\
\text { (SDR Million) } \\
\end{array}$ \\
\hline PRGF & $12 / 06 / 2004$ & $12 / 05 / 2007$ & 54.99 & 7.86 \\
\hline PRGF & 06/28/1996 & 06/27/1999 & 69.48 & 13.90 \\
\hline Stand-by arrangement & $05 / 27 / 1994$ & $05 / 26 / 1995$ & 23.16 & 12.50 \\
\hline
\end{tabular}

VI. Projected Payments to Fund: (SDR million; based on existing use of resources and present holdings of SDRs):

\begin{tabular}{|c|c|c|c|c|c|}
\hline & & & orthco & & \\
\hline & $\underline{2005}$ & $\underline{2006}$ & $\underline{2007}$ & $\underline{2008}$ & $\underline{2009}$ \\
\hline Principal & 4.03 & 2.78 & & & \\
\hline Charges/interest & $\underline{0.21}$ & $\underline{0.27}$ & $\underline{0.27}$ & $\underline{0.27}$ & $\underline{0.27}$ \\
\hline Total & 4.24 & 3.05 & 0.27 & 0.27 & 0.27 \\
\hline
\end{tabular}




\section{Implementation of HIPC Initiative:}

The Republic of Congo is likely to reach HIPC Initiative decision point by end-2005, once it establishes a track record under the PRGF-supported program approved by the Board on December 6, 2004.

\section{Safeguards Assessments:}

The Bank of the Central African States (BEAC) is the regional central bank of Central African States, of which Republic of Congo is a member. A safeguard assessment of the BEAC completed on August 30, 2004 found that BEAC has implemented a number of measures to strengthen its safeguards framework since the 2001 safeguards assessment, but further progress needs to be made in key areas.

The main recommendations of the assessment, applicable to the BEAC as an institution, include: (i) preparation of financial statements in full accordance with an internationally recognized accounting framework, initially the ECB guidelines; (ii) publication of its full financial statements, together with the auditor's report, starting with the 2003 financial statements; (iii) formulation of Board-approved formal guidelines under which the BEAC Governor is authorized to make exceptional advances to BEAC member countries; (iv) annual review by BEAC internal audit department of the process of program data reporting of member countries to the IMF; (v) implementation of a risk-based audit approach, and finalization of a charter, for the internal audit function; and (vi) systematic follow-up of all recommendations pertaining to the BEAC's system of internal controls to be coordinated by internal audit department, with regular reporting to the Audit Committee and the BEAC Governor.

Other priority recommendations of the assessment, but of a country specific nature, were: (i) the BEAC should clarify with its member countries that hold foreign reserves outside the BEAC the statutory basis and circumstances for doing so, to avoid an apparent conflict with the BEAC statutes and to ensure full transparency of reporting of reserves by the member country; (ii) the BEAC and its member states are encouraged to establish a mechanism to prevent IMF overdues and facilitate timely payments through advance acquisitions of SDRs and an authorization to debit an SDR account of the member; and (iii) the BEAC should cooperate with its members to reconcile and confirm the Treasury balances to ensure that the balances reported by the BEAC with regard to credit to government, as reflected in the accounts of the Treasuries, are in agreement with the BEAC.

\section{Exchange Rate Arrangement:}

The Congo's currency is the CFA franc, which is pegged to the euro at a fixed rate of CFAF $655.957=$ euro 1. On July 15, 2005, the rate of the CFA franc was CFAF 789.350 per SDR. The Congo does not impose any restrictions on the making of payments and transfers for current international transactions. 


\section{Article IV Consultations:}

Consultations with the Congo are on the standard 24-month cycle. The 2004 consultation discussions started in Brazzaville in February 2004 and concluded in Washington in March 2004. The staff report (IMF Country Report No. 04/232, July 2004) was considered by the Executive Board on June 10, 2004.

\section{FSAP Participation :}

N/A.

XII. Technical Assistance :

Subject

Modernization of tax and customs administrations

Follow-up mission

Budget functional classification

Multisector statistics

Resident expert on statistics

Balance of payments

Budget, tax, and customs

Resident tax expert

Tax administration

Tax administration

Budget, expenditure classification

$\begin{array}{lll}\text { Department } & \text { Staff Member } & \text { Date } \\ \text { FAD } & \text { Gilles Montagnat- } & \text { February 2004 } \\ & \text { Rentier, Eric } & \\ & \text { Lesprit and } & \\ & \text { Ahmed Boilil } & \end{array}$

FAD

Mr. Lepage

November 2003

FAD

Messrs. Bouley,

Hélice, and

Lepage

STA

Messrs. Marie,

Maiga, and Mmes.

Fisher, Matei,

Razin, and

Balvani

STA

Mr. Sin

STA

Mr. Fiévet

Messrs. Bouley, Moussa, Brik, and Mrs. Tricoire

FAD

Mr. Laurent

FAD

Mr. Grandcolas

Mr. Grandcolas

and Mr. Castro
1995-97

October 2003

May 2002

Since October 2001

June 2001

April-May 2001

November 1995-

April 1996

November 1994

Request under

consideration

\section{Resident Representative:}

A senior resident representative took up his assignment in September 1995, but was recalled to headquarters shortly after the outbreak of the civil strife in June 1997. A new resident representative is expected to take office in September 2005. 


\section{Republic of the Congo \\ Relations with the World Bank Group}

(As of June 7, 2005)

\section{Introduction}

1. This annex first underscores the importance that the Government of the Republic of Congo (ROC) attaches to effective partnership with external creditors, donors and foreign investors. It then summarizes the strategy and activities of the World Bank Group (IDA, IFC, and MIGA) in ROC. It concludes with a description of areas of specific collaboration between the World Bank Group and the International Monetary Fund.

\section{Partnership in the Republic of Congo's development strategy}

2. Three successive rounds of civil war (1993, 1997, and 1998/99), compounded by the legacy of three decades of poor economic management under a centrally planned economy, have taken a heavy toll on the Republic of Congo. As a result, Congo was cut off from international financial assistance throughout much of the 1990s. Throughout this period, conflict and poverty fueled each other - and Congo has become an illustration of the "conflict trap", such that each successive round of conflict resulted in economic decline and heightened social tensions, leading to an increased chance of renewed fighting.

3. Arrears to the World Bank and IMF were cleared in August 2001, paving the way for a resumption of lending activities. In 2001, IDA and the IMF responded: (i) IDA with a program of lending and non-lending activities for the following 12-24 months, outlined in a Transitional Support Strategy (TSS), which was updated in 2003; (ii) the IMF with a series of StaffMonitored Programs, with the intention of moving towards a three-year PRGF program. In September 2004 at the Donor Meetings in Paris, donors pledged US\$443 million in financial assistance to Congo over the next few years.

4. The government's development strategy, as formulated in its I-PRSP, which was transmitted to the Bank and the Fund on October 5, 2004, has five broad goals: (i) consolidating peace and good governance; (ii) sustaining macroeconomic stability and tapping more fully the potential growth of key sectors; (iii) improving access to social services; (iv) rehabilitating and expanding infrastructure; and (v) intensifying the fight against HIV/AIDS. A joint staff advisory note (JSAN) on the I-PRSP was approved by the Boards of the Bank and the Fund in December 2004. 


\section{Bank Group strategy and operations (IDA, IFC , and MIGA) ${ }^{1}$}

5. Overall strategy. On July 1, 2001 the Bank reengaged in the Congo within the context of a Transitional Support Strategy (TSS) with a variety of operations for the following 1224 months, including a Post-Conflict Economic Rehabilitation Credit, an Infrastructure Rehabilitation Credit, an Emergency Demobilization and Reintegration Credit, a Governance and Transparency Capacity Building Credit, and an Emergency Recovery and Community Support Project (as described hereunder).

\section{Financial assistance under TSS}

6. The Board approved a Post-Conflict Economic Rehabilitation Credit (PERC) in the amount of SDR 30 million (US\$37.6 million) on July 31, 2001. The Credit was disbursed in August 2001 and aimed to support the implementation of key structural reforms, enhanced management of fiscal resources, and improved governance and transparency in the oil sector. The project has been satisfactorily implemented and was closed on June 30, 2004.

\section{The Infrastructure Rehabilitation and Improvement of Living Conditions Project} was approved by IDA on May 2, 2002 in the amount of SDR 32.2 million (US\$40 million), and became effective in December 2002. It supports the long-term process of reconstruction and rehabilitation of critical infrastructure, in particular railways, urban, interurban and rural roads, and drainage.

8. IDA began providing support for demobilization via an Emergency Demobilization and Reintegration Project in the amount of SDR 4.0 million (US\$5 million) which was approved on July 31,2001 . The project aims to contribute to the ongoing efforts to consolidate peace in the Congo, and to offer reintegration options to ex-combatants who have joined the ranks of the unemployed after the signing of the Cease-fire agreement.

9. The Transparency and Governance Credit was approved on February 7, 2002 in the amount of SDR 5.6 million (US\$7 million). The project was designed to address key issues of efficiency, transparency and governance in oil and financial management operations, as well as in the privatization of public enterprises. Overall coordination is ensured by an Inter-Ministerial Reform Implementation Committee, and an inter-agency technical committee. Project implementation is on track and its development objectives are being met. The Credit is set to close on December 31, 2007.

\section{The Emergency Recovery Community Support Project was approved on}

June 24, 2003 in the amount of SDR 20.3 million (US\$41 million) to provide early support to the Congo in its decentralization and community recovery process. The Project's principal objective is to support the recovery of communities living in smaller municipalities and rural areas (all

\footnotetext{
${ }^{1}$ The Bank re-opened a Country Office in Brazzaville, and a Country Manager assumed his post in May 2001.
} 
areas out of the two cities of Brazzaville and Pointe Noire). The Credit became operational on September 16, 2003. Part of the project is grant financed (up to \$US13 million).

11. The program of financial assistance was complemented by several grants, in particular under the Post-Conflict Fund (PCF). This included: (i) a US\$915,000 PCF grant to help prepare the 2001 TSS (approved in 1998, implemented by the French Development Agency and the European Union); (ii) a US\$1,000,000 PCF grant to support community action for reintegration and recovery of youth and women (approved in 2001, implemented by the UN Development Program); (iii) a US\$708,000 grant from the Japanese Social Development Fund to support a Community Action for Reintegration and Recovery project; and (iv) a US $\$ 300,000$ grant from the Statistical Capacity Trust Fund for Poverty Reduction Strategy Papers (approved in 2003) to strengthen institutional capacity to monitor poverty indicators. The PCF grants proved critical in re-engaging in the Congo, by providing the necessary resources for strategic work and by allowing for early, targeted support to war-affected groups.

\section{TSS update}

12. A TSS update was discussed by the Board on August 8, 2003. The new TSS aims to support the Government's efforts to lift the country out of the conflict trap by outlining a new program of continued Bank support, building on achievements made over the past two years towards peace, political reconciliation and economic recovery. The TSS intends to consolidate and deepen these reforms, within the context of the PRSP process, with a view to moving to a formal CAS as soon as conditions allow.

13. The TSS envisages a lending program which includes an Economic Recovery Credit, a HIV/AIDS project, an Education project, and a Multi-sector infrastructure and trade facilitation project (as described hereunder). For future years is envisaged a second Economic Recovery Credit, an Agriculture and Rural Roads Rehabilitation project, a Private Sector Development project, and a Demobilization and Reintegration Project.

\section{Financial assistance under TSS update}

14. An Economic Recovery Credit in the amount of US\$30 million equivalent was approved by the Board on December 7, 2004. The Credit focuses on transparency in the oil sector, improved management of domestic debt and more efficient public investment. The Credit covers an 18 month period and is to be disbursed in two tranches. The first tranche has been released upon effectiveness and the second tranche will be when the following triggers have been satisfied: (i) the action plan of the national oil company (SNPC) ${ }^{2}$ to improve transparency in the oil sector has been satisfactorily implemented; (ii) an agreement has been reached between the government and its domestic commercial creditors on a common discount factor to be applied to the outstanding stock of debt, as certified by independent auditors; and (iii) the government has

${ }^{2}$ Société National de Pétrole du Congo (SNPC) is Congo's national oil company. 
adopted and implemented an action plan for reforming and improving the management of its self-financed public investment program (PIP), and submitted a draft PIP for FY06-07 to IDA for its review.

15. The goal of the HIV/AIDS and Health Project is to mitigate the negative impact of the HIV/AIDS epidemic on the socio-economic development of the Republic of Congo. It was approved in the amount of US\$19 million on April 20, 2004. Its development objectives are to support government actions to slow the spread of HIV-AIDS, and to strengthen assistance and care for people infected or affected by HIV-AIDS. To reach these objectives, the project:

(i) supports civil society and community initiatives for HIV-AIDS prevention and care;

(ii) expands access to treatment of opportunistic infections; (iii) provides care and support for people living with HIV-AIDS; (iv) provides care for orphans and other highly vulnerable children; and (v) aims to reduce transmission of the disease among high risk groups. The project will close in 2009.

16. A Support to Basic Education project for US $\$ 20$ million was approved by the Board on September 23, 2004. It aims at assisting Congo in the mitigation of the current crisis of the education sector, and at establishing the grounds for a solid development of a medium and longterm sector program. The proposed project has the following four components: (i) capacitybuilding of the Ministry of Education; (ii) rehabilitation of school infrastructure, damaged during the war, and/or deteriorated due to lack of maintenance; (iii) improvement of the quality of education through teacher training, better textbooks/teaching guides and guaranteeing access to key textbooks for all students; and (iv) support for out-of-school youth and vulnerable populations by providing them with training, literacy and numeracy programs. The project is expected to close in 2008.

17. The Bank is also currently preparing a Multi-sector Infrastructure and Trade Facilitation Project (FY05; US\$23 million) to address priority infrastructure needs in urban water and electricity. The project will finance rehabilitation of key physical infrastructure, and introduce private sector management of the water utility via a management contract, and private sector handling of billing and collection in the electricity utility. Private sector participation, together with appropriate tariffs will help improve management of the sectors, and help place them on a stronger financial footing.

\section{Non-lending activities}

18. In parallel, the Bank has prepared a Public Expenditure Management Review, and initiated a study on natural resources management, and a labor market analysis. These efforts are expected to help tackle some of the key transparency and effectiveness issues the country is facing with regard to economic management.

19. In the context of the HIPC initiative, a Debt Sustainability Analysis (DSA) is currently under preparation. Other non-lending services planned for FY05-FY06 include (i) an Agricultural Policy Note, (ii) a Forestry Survey, (iii) a Legal and Judicial Assessment, and (iv) a Combined Country Procurement/Country Financial Accountability Assessment. 
IFC

20. IFC has no current investments in Congo. Participation in a previous oilfield development was swapped for equity in the sponsor, a South African company. Prior forestry investments have been liquidated. New support may be available for financial sector restructuring, SME development, infrastructure rebuilding, and development of the oil sector and mining.

\section{MIGA}

21. Congo has contributed to the General Capital Increase in March 2003. MIGA has no exposure in the Republic of Congo, and there is no active application. However, investors have expressed interest in the power and telecommunications sector.

\section{Bank-Fund collaboration in specific areas}

22. The IMF and World Bank staff maintain a close collaborative relationship in supporting policies to help the Congo consolidate civil peace and recover from a decade of recurring conflicts, sustain macro-economic stability, improve governance, reverse a marked decline in social indicators, and promote sustainable development. Exchange of information and discussion on progress in the implementation of the reform program take place on a regular basis between the Bank and the Fund. Joint missions are carried out to review progress.

\section{Areas where the World Bank leads and there is no direct IMF involvement:}

- health and education sectors, for which two projects are under preparation;

- state disengagement from productive sectors through privatization/restructuring of public utilities enterprises and commercial banks; and

- transparency in the use of public funds, notably through the reform of public procurement and the institution of the Office of Auditor General (Cour des Comptes).

\section{Areas where the World Bank leads and its analysis serves as input to the IMF:}

- review of selected issues in the oil sector, including the recently completed audit of the national oil company (SNPC) and the follow up action plan;

- management, taxation, and governance in the forestry sector;

- social policies;

- assistance in PRSP preparation;

- banking and more generally financial sector;

- public expenditure management review; and

- economic evaluation of large-scale public investment projects. 
Areas of shared responsibility:

- governance in the oil sector;

- efficient use of public resources;

- oil revenue mobilization;

- governance and fiscal impact of large investment projects;

- preparatory work on HIPC issues; and

- statistics and measurement issues.

Areas where the IMF takes the lead and its analysis serves as an input to the World Bank:

- competitiveness/exchange rate issues;

- tax policy and administration; and

- customs/tariffs/trade policy.

Areas where the IMF takes the lead and there is no direct World Bank involvement:

- fiscal policy;

- monetary policy;

- external payments regime;

- non-oil revenue mobilization; and

- macroeconomic statistics issues. 


\section{REPUBLIC OF CONGO: TABLE OF COMMON INDICATORS REQUIRED FOR SURVEILLANCE \\ As of July 8, 2005}

\begin{tabular}{|c|c|c|c|c|c|}
\hline & $\begin{array}{l}\text { Date of latest } \\
\text { observation }\end{array}$ & $\begin{array}{l}\text { Date } \\
\text { received }\end{array}$ & $\begin{array}{c}\text { Frequency } \\
\text { of } \\
\text { Data }^{6}\end{array}$ & $\begin{array}{l}\text { Frequency } \\
\text { of } \\
\text { Reporting }\end{array}$ & $\begin{array}{c}\text { Frequency } \\
\text { of } \\
\text { publication }^{6}\end{array}$ \\
\hline Exchange Rates & $7 / 06 / 05$ & $7 / 06 / 05$ & $\mathrm{D}$ & $\mathrm{D}$ & $\mathrm{D}$ \\
\hline International Reserve Assets and Reserve Liabilities of the Monetary Authorities ${ }^{1}$ & March 05 & May 05 & Q & Q & Q \\
\hline Reserve/Base Money & April 2005 & June 2005 & M & M & M \\
\hline Broad Money & May 2005 & May 2005 & $\mathrm{M}$ & M & M \\
\hline Central Bank Balance Sheet & March 05 & May 2005 & M & M & M \\
\hline Consolidated Balance Sheet of the Banking System & April 2005 & May 2005 & M & M & M \\
\hline Interest Rates ${ }^{2}$ & May 2005 & May 2005 & & & M \\
\hline Consumer Price Index & March 05 & May 2005 & M & M & M \\
\hline Revenue, Expenditure, Balance and Composition of Financing ${ }^{3}-$ General Government $^{4}$ & $\mathrm{~N} / \mathrm{A}$ & N/A & N/A & $\mathrm{N} / \mathrm{A}$ & $\mathrm{N} / \mathrm{A}$ \\
\hline Revenue, Expenditure, Balance and Composition of Financing ${ }^{3}-$ Central Government & March 05 & May 05 & Q & Q & Q \\
\hline Stocks of Central Government and Central Government-Guaranteed Debt ${ }^{5}$ & March 05 & May 05 & Q & Q & Q \\
\hline External Current Account Balance & 2003 & Feb 2004 & A & A & A \\
\hline Exports and Imports of Goods and Services & 2003 & Feb. 2004 & A & A & A \\
\hline GDP/GNP & 2004 & May 2004 & A & A & A \\
\hline Gross External Debt & March 05 & May 2005 & Q & Q & Q \\
\hline
\end{tabular}

${ }^{1}$ Includes reserve assets pledged or otherwise encumbered as well as net derivative positions.

${ }^{2}$ Both market-based and officially-determined, including discount rates, money market rates, rates on treasury bills, notes and bonds.

${ }^{3}$ Foreign, domestic bank, and domestic nonbank financing.

${ }^{4}$ The general government consists of the central government (budgetary funds, extra budgetary funds, and social security funds) and state and local governments.

${ }^{5}$ Including currency and maturity composition.

${ }^{6}$ Daily (D), Weekly (W), Monthly (M), Quarterly (Q), Annually (A); Irregular (I); Not Available (NA) 


\section{Statement by the IMF Staff Representative August 1, 2005}

1. This statement contains information on developments in the Republic of Congo since the circulation of the staff report for the first review of the three-year arrangement under the Poverty Reduction and Growth Facility. The information does not alter the thrust of the staff appraisal.

2. The five prior actions related to oil sector reform and transparency, banking sector reform, and public finance management were implemented:

- The audits of oil costs for 2003 for all production-sharing contracts (as defined in these contracts) were completed by audit firms of international reputation in accordance with international standards, and the reports were submitted to the government. The auditors verified the eligibility of costs that were deducted, as well as the execution of other aspects of the contracts. Their conclusions point to substantial additional profit payments that are owed by oil companies to the government; the authorities have entered into negotiations with the companies to recover past payments due.

- A reconciliation of the amount of oil revenues deposited in government bank accounts, as reported in the quarterly certification statements, and the total oil revenues reported in the government financial operations tables (TOFEs) for 2003 and 2004 was completed by an audit firm of international reputation. The auditors noted lack of access to source documentation to verify the accuracy of some parts of the information provided by the authorities. The reports, published on the Internet site of the Ministry of Economy and Finance (www.mefb-cg.org), showed large differences between oil revenues due to the government and receipts recorded in the TOFE (of about 2 percent of GDP in 2003 and 5 percent of GDP in 2004). These reports and information received subsequently from the authorities indicate that the following factors explain the differences: (i) receipts in the TOFE are recorded on a cash basis while estimates by the auditor of oil revenues due to the government are on an accrual basis; (ii) costs of financial transactions carried out by the national oil company (SNPC) on behalf of the government are netted out from receipts reported in the TOFE, but not from the oil revenues estimated by the auditors; (iii) the price used to value government oil sales by the auditors differs, sometimes quite substantially, from the price at which the oil was actually sold and recorded in the TOFE (see Box 2 of staff report); and (iv) some short-term oil-based loans (allowed under the program) contracted by the government were not recorded in the TOFE. The staff will pursue detailed discussions on this issue with the authorities in the period ahead. 
- With a view to strengthening the recovery of loans, the government established a list of the principal delinquent debtors of the Congolese banking system, based on information from the La Centrale des Risques; the list was circulated to banking establishments and Public Treasury.

- The government signed a contract with an audit firm of international reputation to conduct annual external audits of the national oil refinery for 2003 and 2004. The completion of these audits is scheduled for end-December 2005.

- $\quad$ The government adopted a decree on June 29, 2005, to implement a new price structure for refined petroleum products which incorporates: (i) an increase of CFAF 115/liter in the price of jet fuel sold to international airlines, (ii) an increase of CFAF 40/liter in the price of gas oil sold to international shipping companies, and (iii) a reduction of 25 percent in the margins (transport, storage, distribution, and marketing) in the price structure.

3. In addition, the implementation of the structural measures at end-June 2005 was broadly satisfactory. The government prepared and submitted to Fund staff a table tracking poverty-reducing spending in 2004 (structural performance criterion). The SNPC prepared statements on the sources and uses of funds for the consolidated activities of the SNPC group (structural benchmark). Staff's preliminary assessment is that the coverage of the cash flow table would need to be extended. Separately, the oil certification report for the first quarter of 2005 was published on the government's Internet site (structural benchmark); the report notes that the proceeds from one oil shipment made at end-March 2005 (estimated at about CFAF 19 billion) have not yet been received by the treasury as of end-June - this shipment appears to be subject to litigation proceedings. The auditors noted continued lack of information from one of the operators (see Box 2 of staff report), and they reported that, unlike in the past, they did not have access to bank account information to verify information on government cash receipts.

4. The authorities continue to make progress in normalizing relations with external creditors. They reported that bilateral agreements have been signed with all Paris Club creditors. Discussions took place in the first half of 2005 with a number of non-Paris Club official bilateral creditors who indicated, in principle, their willingness to provide debt relief to Congo at the time of the Decision Point under the enhanced HIPC Initiative. Discussions with the remaining official bilateral creditors are envisaged for August 2005. The last meeting between the authorities and the London Club Steering Committee took place in July 2005 and the two parties agreed to pursue discussions in the period ahead. In addition, information received from the authorities indicates that as at end-June 2005, Congo was current on its external debt service obligations to multilateral and Paris Club creditors.

5. As regards budget execution, preliminary data through end-May 2005 suggest that expenditures were kept under control, and non-oil revenue mobilization continued to be strong. Nonetheless, oil revenues were lagging somewhat behind the monthly mobilization rate envisaged for the second quarter of 2005. 
Press Release No. 05/181

FOR IMMEDIATE RELEASE

August 3, 2005
International Monetary Fund

Washington, D.C. 20431 USA

\section{IMF Executive Board Completes First Review Under the Republic of Congo's PRGF Arrangement and Approves US\$11.41 Million Disbursement}

The Executive Board of the International Monetary Fund (IMF) has completed the first review of the Republic of Congo's performance under an SDR 54.99 million (about US\$84.4 million) Poverty Reduction and Growth Facility (PRGF) arrangement (see Press Release No.04/262). The completion of the review enables the release of a further SDR 7.86 million (about US\$11.41 million), which will bring the total amount drawn under the arrangement to SDR 15.72 million (about US\$23.47 million).

In completing the review, the Board waived the nonobservance of one quantitative performance criterion relating to the floor on external arrears payments and one structural performance criterion relating to the completion of external audits of oil costs for 2003 for all productionsharing contracts. The Board also approved modification of a quantitative performance criterion on external arrears payments.

Following the Executive Board's discussion on the Republic of Congo's economic performance, on August 1, 2005, Mr. Agustín Carstens, Deputy Managing Director and Acting Chair, stated:

"The Republic of Congo (hereafter "Congo") has made a good start in implementing its mediumterm program, which is supported by an arrangement under the Fund's Poverty Reduction and Growth Facility (PRGF). The security situation has been improving with the government's program for demobilizing former combatants moving forward, although with some delays.

"Macroeconomic performance strengthened over the past year and a half. Improved economic management, coupled with an exceptionally favorable international environment-in particular, a strong rise in oil prices - resulted in an increase in economic growth and a significant strengthening in the fiscal and current account balances. However, inflation accelerated in 2004, owing primarily to supply disruptions on the Pointe Noire-Brazzaville rail line and banks have remained cautious about advancing credit, amid persistent fragility in the banking system.

"There has also been a welcome improvement in governance. This has included steps to enhance transparency with regard to oil sector transactions, such as the publication of the full 2003 audit report of the national oil company and the quarterly reports of the certification of oil revenues. 
"Notwithstanding the recent positive developments, Congo continues to face major challenges. These include the need to tackle structural weaknesses in key sectors of the economy, including banking, electricity, and refined petroleum products, and to address widespread poverty by working toward the Millennium Development Goals (MDGs). Meeting these challenges will require structural reforms and prudent macroeconomic management. In this context, the authorities plan to use oil revenues in excess of budget assumptions to raise spending on povertyrelated outlays, accelerate the clearance of arrears to external creditors, and normalize relations with domestic creditors. Measures are also being taken to strengthen the management of public finances and the monitoring of public spending, to improve the business climate, and to enhance the overall governance framework.

"To accelerate progress toward achieving the MDGs, poverty-related spending is to be raised by about one percent of GDP in 2005 relative to the original program. Some of the challenges facing Congo are already being addressed this year, and additional resources will be devoted to the priority sectors identified in the interim Poverty Reduction Strategy Paper.

"Based on a preliminary debt sustainability analysis, jointly undertaken by IMF and World Bank staff, Congo's external debt burden would remain above the HIPC threshold even after application of traditional debt-relief mechanisms. Congo is thus likely to qualify for early assistance under the enhanced HIPC Initiative provided its macroeconomic program, supported by the PRGF arrangement, remains on track. Debt relief under the enhanced HIPC Initiative would help accelerate progress toward meeting the MDGs, although capacity constraints would need to be tackled with Fund and donor technical assistance to enable absorption of related resources," Mr. Carstens said.

The PRGF is the IMF's concessional facility for low-income countries. PRGF-supported programs are based on country-owned poverty reduction strategies adopted in a participatory process involving civil society and development partners and articulated in a Poverty Reduction Strategy Paper (PRSP). This is intended to ensure that PRGF-supported programs are consistent with a comprehensive framework to foster growth and reduce poverty. PRGF loans carry an annual interest rate of 0.5 percent and are repayable over 10 years with a $5 \frac{1}{2}$-year grace period on principal payments. 


\section{Statement by Damian Ondo Mañe, Executive Director for the Republic of Congo August 1, 2005}

\section{Introduction}

On behalf of my Congolese authorities, I would like to express my appreciation to Management and the staff for their continued support and policy advice given to the Republic of Congo under the current and past programs. My authorities welcome this first review under the PRGF and hope that in recognition of progress achieved in consolidation peace and security, maintaining a stable macroeconomic environment, deepening structural reforms, improving its ownership of program implementation and of the I-PRSP, Congo will attain the decision point before the end of this year. All these achievements under successive SMPs and the recent new three-year PRGF Fund-supported program would not have been possible without the support of other development partners, in order to lay the foundations for broadbased economic growth, needed to reduce poverty.

My Congolese authorities at the highest levels are aware of the major challenges facing the country, including those related to the need to address structural weaknesses in the banking, refined petroleum products, and electricity sectors. In this regard, I would like to point out that the authorities have implemented the five prior actions related to the oil and banking sectors, as well as public finance management. My authorities are committed to maintaining peace and stability in the Congo, in order to implement sound macroeconomic, structural and sectoral policies to sustain macroeconomic stability, alleviate poverty, and strengthen institutional capacity. They are determined to consolidate progress made in improving governance and accountability, which would help them better deal with the daunting challenges ahead. Support from the international community will also be essential to help them improve the country's administrative and institutional capacities.

Since the Executive Board's approval of a three-year PRGF arrangement last December 2004, Congo's performance under this program has remained broadly satisfactory for the period from October 1, 2004 to end-March 2005. However, my authorities request a waiver for the nonobservance of the performance criteria on payments of external arrears and completion of external audits of oil costs for 2003, as well as modification of one performance criterion, in order to complete the first review. They are committed to continue to implement strong policies and reforms in the period ahead. They are also aware of the importance of establishing a sound environment in which private sector activity can flourish.

\section{Background and Recent Developments}

As Directors are aware, Congo experienced a decade of political instability characterized by three civil wars in the 1990s, which resulted in important loss of human lives and negative socio-economic consequences. Since the end of the conflicts in 1999, the political environment has improved and the authorities have seized this opportunity to implement policies aimed at restoring macroeconomic stability. The Staff-Monitored Programs have been instrumental in this regard. With the consolidation of peace, a stronger economic 
performance emerged in the post-conflict period, which was not only helped by enhanced macroeconomic management, but also by the rise in oil prices. Non-oil real GDP increased by about $9 \frac{1}{2}$ percent per annum on average during 2000-04, driven by improvements in agriculture, commerce, and transportation. Inflation decelerated, helped by the trend toward fiscal consolidation, a more reliable supply, and a strengthening of the euro vis-à-vis the U.S. dollar. Although some setbacks were encountered during the implementation of economic reforms under the 2001-03 SMPs, my authorities have demonstrated resolve to break away from the past economic management practices and established a strong track record on program implementation since late 2003.

In the fiscal sector, the fiscal position improved, due to tighter control of expenditure, high oil revenues, and mobilization of non-oil revenues. In the public finances, the authorities took steps to centralize a large portion of fiscal revenues and expenditures in the budget; and they improved tracking of oil revenues and budgetary outlays.

On the structural front: progress was made in enhancing oil sector transparency, and more broadly natural resource sector transparency. Unprecedented in Africa has been the authorities' emphasis on internet publication, including of quarterly reports on oil revenue certification, as well as internet publication of the full 2003 audit report of the national oil company (SNPC), the terms and conditions of the financial transactions carried out by the SNPC for the government, and all active production-sharing agreements. The authorities have announced their commitment to adhere to the EITI.

Regarding the external sector: the authorities have taken important steps to improve relations with creditors since the beginning of the 2003. Moreover, the government has contracted no new loans with maturity exceeding one year using oil collateral since October 2002.

For 2004 as a whole, Congo benefited from a favorable external environment, with strong increase in oil prices, one of the main country's export products. Real GDP growth rebounded, reflecting favorable terms of trade, and a slight increase in oil production. Inflation rate, although it increased somewhat, due to supply disruption on the Pointe NoireBrazzaville rail line, remained subdued. As a result of increase in oil prices, the fiscal and current account balance position improved. In the fiscal area, revenue performance recorded a significant increase, stemming from higher oil prices, improved tax, and customs administration, including the reform of the computer systemic the customs office at Pointe Noire. Regarding primary expenditure, although its level exceeded the program, this was due a problem beyond the authorities' control. Indeed, in anticipation of lower water levels in the Congo River, investment projects in the remote north planned for the first half of 2005 were executed in the last quarter of 2004. This phenomenon of lower water levels in the Congo River happens sometimes during a long and severe dry season period.

With regard to the poverty-related spending, performance was below expectations, owing to the lack of trained personnel and weak monitoring system for budget execution. The authorities are determined to take all necessary steps to correct this problem. With regard to the banking system, to address the critical situation facing one bank, the government has 
temporarily taken over the bank, with the view to protect depositors, allow an orderly restructuring, and prepare it for reprivatization. Other key actions undertaken by the authorities in other areas include the strengthening of governance and transparency, with the publication of information through internet, related to the quarterly oil revenue certifications, large parts of the 1999-2001 and 2002 external independent audits of the SNPC, and all active production-sharing agreements. Moreover, an external audit of the national oil refinery (CORAF) for 2002 was completed in December 2004.

Overall, my authorities are hopeful that in recognition of their efforts to improve macroeconomic management and governance, the Republic of Congo will benefit from assistance under the Heavily Indebted Poor Countries (HIPC) Initiative before the end of this year, so that the country's heavy debt burden can be brought down to more sustainable levels and the authorities can increase pro-poor outlays.

\section{Implementation of the PRGF-supported programs}

The Congo's program is based on two pillars, namely enhancing the transparency of public resources management, in particular in the oil sector, and improving fiscal discipline. Overall, as stressed above, the Congo's implementation of the PRGF yielded positive results over the period considered.

Although the primary budget surplus was lower-than programmed, the end-December 2004 quantitative benchmarks were met. As stressed in the staff report, factors beyond the authorities' control have occurred. Most quantitative criteria for end-March 2005 were observed, with the exception of targets on payments of external arrears at end-December 2004 (quantitative benchmark) and end-March 2005 (quantitative performance criterion). With regard to structural performance criteria for December 2004 and March 2005, the Congo observed two out of three, namely related to the 2002 external audit of the CORAF and the tracking of quarterly expenditure execution in 2004. Most structural benchmarks for December 2004 and March 2005 were observed, in particular, the completion of the SNPC's 2003 external audit and publication of the entire report on the Finance Ministry's website (www.mefb-cg.org). Regarding CORAF and SNPC, the authorities have taken good note of weaknesses in these companies' accounting practices and internal control procedures and will take the necessary steps to address them.

\section{Medium-Term Macroeconomic Framework and policy agenda for 2005}

In light of recent developments, the macroeconomic forecast for 2005-07 was revised relative to the PRGF scenario to reflect higher oil prices; lower oil production; payments of postcutoff-date arrears; as well as higher poverty-related spending. Thus, the authorities' main medium-term macroeconomic objectives are as follows: (a) an expansion of output with the real GDP growth reaching an average of about 5.2 percent; (b) the achievement of an annual inflation rate around 2 percent, and (c) a primary surplus of 17.7 percent of GDP in 2005 and 10.3 percent of GDP on average in 2006-07, and (d) an external current account surplus averaging about 3.3 percent of GDP. 
In the fiscal area, the main objective behind the revision of Congo's fiscal policy is to help the authorities to raise poverty-related spending, while allowing an increase in the primary budget surplus. To address the constraints facing the economy, including the structural problems that emerged in the banking, fuel and energy sectors, the authorities intention to present a 2005 supplementary budget to parliament later in the year. They are also committed to implementing a prudent expenditure policy with the view to freeing up resources to help boost pro-poor expenditures identified in the I-PRSP. To ensure an effective use of public spending, my authorities plan to prepare a quarterly table with data tracking the various stages of the expenditure process. They also envisage accelerating preparations for the introduction of a functional classification of government spending. Furthermore, they plan to emphasize staff training in the education and health sectors to strengthen absorptive capacity.

For 2005, total revenues are expected to be higher than programmed, reflecting primarily higher oil prices. The mobilization of oil revenues is expected to further improve through the strengthening of quarterly certification process and the SNPC's improved performance in marketing the governance's share of oil production. Non-oil revenue mobilization will benefit from administrative reforms, including measures against fraud and tax evasion, as well as from limits on discretionary tax exemptions. Also noteworthy is the fact that the authorities are planning to settle domestic payment arrears transparently and equitably. They envisage the preparation of a plan by September this year.

Monetary policy will continue to be carried out within the regional framework of the CEMAC to ensure low inflation and keep the foreign exchange reserves at a comfortable level. Cognizant of the risks of inflation stemming from the inflow of financial resources, given that international oil prices are expected to be buoyant over the next few years, the authorities stand ready to take corrective actions, in accordance with current CEMAC and BEAC rules.

Regarding the Millennium Development Goals (MDGs), the authorities' immediate objectives are based on the eradication of extreme hunger, the attainment of 100 percent youth literacy, and the promotion of gender equality. However, should additional resources become available from oil receipts and debt relief under the enhanced HIPC Initiative, the authorities stand ready to make efforts towards achieving other key MDGs.

\section{Structural Reforms and Governance Issues}

The key reform objectives in the oil sector and public finance management will remain as initially envisaged in the PRGF program. However, the authorities are also committed to address the new structural challenges that have emerged in the banking, fuel and energy, in order to limit future recourse to the budget, as well as enhance accountability and transparency.

With regard to the banking sector, the authorities of the Republic of Congo recognize the need to address the fragility of the banking system. Their key objectives are to promote greater market discipline and improve the governance framework as regards bank loans. 
Among near term measures are the need to intensify surveillance of the COFIPA bank by the COBAC and the conduct of an audit of the quality of the bank's portfolio. Moreover, the bank's restructuring plan will be revised to incorporate the results of the audit and more forceful cost-cutting measures. The authorities' plan is to privatize this bank without delay and through a transparent and competitive bidding process. For the recovery of nonperforming loans, action will be taken, which will strengthen market discipline.

In the fuel sector, key objectives envisaged include curtailing losses and reforming the CORAF. To limit future losses, the government will lower margins and raise the prices of jet fuel and gas oil; the CORAF will adopt a plan to curtail its operating costs; a strategy and economic study of the CORAF will also be conducted in collaboration with the World Bank, which will lay the groundwork for restructuring the enterprise. My authorities have requested assistance from the World Bank to conduct a social impact analysis of introducing an automatic price adjustment mechanism in the fuel sector.

In the energy sector, reform of the electricity sector is continuing in the context of the project to rehabilitate the energy and water infrastructures. The authorities are determined to reduce the losses of SNE and the resulting burden on the government budget. Near-term priorities are to improve the SNE's financial situation and its bill collection capabilities. A reconciliation of SNE's arrears to the SNEL is envisaged. A medium-term objective is to improve the sector's bill collection ratio through investment in new meters and other equipment.

My authorities are determined to enhance the transparency of natural resource management. Following the EITI conference in London last March, the Congo was named in a press communiqué as one of the nine countries that had made progress in improving transparency in the management of their oil revenue. Going forward, the authorities intend to work closely with industry and civil society to implement the EITI objectives. Moreover, the authorities are taking steps to bring the Congo back into the Kimberley Process for the certification of diamonds. A geological and mining research firm has been contacted with a view to conducting a study of raw diamond production capacity in the Congo.

\section{Eligibility under the HIPC and DSA}

It is evident from the staff preliminary document that country meets the criteria set the enhanced Heavily Poor Countries (HIPC) Initiative. Indeed, ranked 144th out of 177 countries under the 2004 United Human Development Index, Congo counts among the poorest countries in the world and it is heavily indebted. 70 percent of the population is estimated to live below the poverty line of $1 \$$ a day. Unemployment affects more than 50 percent of the active population, with youth being particularly affected. The Congo's financial situation has been made worse by an unsustainable external debt burden. From staff calculation, it is evident that external debt would remain above the HIPC threshold, even after application of traditional debt relief mechanisms, with a ratio of net present value of debt to government fiscal revenues well above the threshold of 250 percent on the basis of end-2003 data. Therefore, debt relief will be crucial to help accelerate progress toward 
meeting the MDGs. My authorities are fully committed to the adjustment process and to the objectives of poverty reduction. They have also achieved remarkable track record of program implementation. In light of these, they look forward to benefiting from the enhanced HIPC Initiative and reaching of the decision point in 2005.

\section{Poverty Alleviation Strategy}

Work on the preparation of the final PRSP is continuing. The steps that the authorities will implement in 2005 are the following: (i) strengthening the national Committee on Combating Poverty; (ii) strengthening the representation of civil society organizations on the Permanent Technical Secretariat; (iii) organizing a government seminar on the formulation and implementation of the poverty reduction strategy, and proposing measures to address the concerns of private sector and civil society; (iv) developing an action plan for the effective participation of civil society organizations, the private sector, and Parliament in the process of preparing and drafting the final PRSP; (v) conducting surveys on household expenditures and on demography and health; and (vi) preparing a detailed timetable for implementing a functional classification of government expenditures.

In light of some weaknesses encountered in the implementation of the I-PRSP in 2004, as the share of pro-poor spending in total primary expenditures was somewhat below the target, the authorities are determined to refocus their attention on poverty reduction. They plan also to monitor pro-poor spending on a quarterly basis.

My Congolese authorities are aware of the constraints surrounding the implementation of the I-PRSP. In that regard, to further deepen ownership, they remain committed to strengthening the participatory process.

\section{Conclusion}

My Congolese authorities have continued to make significant efforts to consolidate peace and political stability since the country emerged from a conflict situation, which has helped them achieve a good track record of policy and reform implementation.

The authorities have prepared an interim poverty reduction strategy paper, and the final PRSP is expected to be completed by 2006. My Congolese authorities are committed to continuing working closely with their partners to achieve the goals of sustained growth and poverty alleviation and to strengthen institutional capacity. In this context, my authorities are hopeful that they can continue to rely on the support of the international community to help them create a solid foundation for economic development and poverty reduction. Being a post conflict country, my authorities are confronted with daunting challenges. The authorities are determined to address them. However, the high debt burden constitutes a serious obstacle to development. In light of progress achieved so far, they are hopeful that the Congo will access to debt relief this year. 